\title{
Review of Information on
}

Hydrology and Radionuclide

Migration at the Nevada Test Site

1976-1988, and Annotated

Bibliography
J. R. Raymond
M. G. Foley
P. A. Eddy
W. H. Bierschenk
R. W. Wallace
R. P. Harrison

September 1989

Prepared for the U.S. Department of Energy under Contract DE-AC06-76RLO 1830

Pacific Northwest Laboratory

Operated for the U.S. Department of Energy

by Battelle Memorial Institute 


\title{
DISCLAIMER
}

This program was prepared as an account of work sponsored by an agency of the United States Government. Neither the United States Covernment nor any agency thereof, nor Battelle Memorial Institute, nor any or their employees, makes any warranty, expressed or implied, or assumes any legal liability or responsibility for the accuracy, completeness, or usefulness of any information, apparatus, product, or process disclosed, or represents that its use would not infringe privately owned rights. Reference herein to any specific commercial product, process, or service by trade name, trademark, manufacturer, or otherwise, does not necessarily constitute or imply its endorsement, recommendation, or favoring by the United States Government of any agency thereof, or Battelle Memorial Institute. The views and opinions of authors expressed herein do not necessarily state or reflect those of the United States Government or any agency thereof.

\author{
PACIFIC NORTHWEST LABORATORY \\ operated by \\ BATTELLE MEMORIAL INSTITUTE \\ for the \\ UNITED STATES DEPARTMENT OF ENERGY \\ under Contract DE-AC06-76RLO 1830
}

Printed in the United States of America

Available to DOE and DOE contractors from the

Office of Scientific and Technical Information, P.O. Box 62, Oak Ridge, iN 37831; prices available from (615) 576-8401. FTS 626-8401.

Available to the public from the National Technical Information Service,

U.S. Deparment of Commerce, 5285 Port Royal Rd., Springfieid, VA 22161.

NTIS Price Codes, Microfiche A01

Printed Copy

\begin{tabular}{|c|c|}
\hline Pages & $\begin{array}{c}\text { Price } \\
\text { Codes }\end{array}$ \\
\hline$\overline{001-025}$ & $\overline{\mathrm{A} 02}$ \\
\hline $026-050$ & $\mathrm{~A} 03$ \\
\hline 051.075 & $\mathrm{~A} 04$ \\
\hline $076-100$ & A05 \\
\hline $101-125$ & A06 \\
\hline $126-150$ & $\mathrm{~A} 07$ \\
\hline $151-175$ & $\mathrm{~A} 0 \mathrm{~B}$ \\
\hline $176-200$ & $\mathrm{~A} 09$ \\
\hline $201-225$ & A10 \\
\hline $226-250$ & A11 \\
\hline $251-275$ & $\mathrm{~A} 12$ \\
\hline $276-300$ & $\mathrm{~A} 13$ \\
\hline
\end{tabular}


PNL-7101

UC -11

REVIEW OF INFORMATION ON HYDROLOGY AND RADIONUCLIDE MIGRATION AT THE NEVADA TEST SITE 1976-1988, AND ANNOTATED BIBLIOGRAPHY
J. R. Raymond
P. A. Eddy (a)
R. W. Wallace
M. G. Foley
W. H. Bierschenk (b)
R. P. Harrison

September 1989

Prepared for

the U.S. Department of Energy

under Contract DE-AC06-76RLO 1830

Pacific Northwest Laboratory

Richland, Washington 99352

(a) IT Corporation, Richland, Washington

(b) Geological Engineer/Hydrogeolog ist

Eugene, Oregon 


\section{EXECUTIVE SUMMARY}

The purpose of this report is to provide information on changes in the state of knowledge on the hydrology and radionuclide migration that have occurred at the Nevada Test Site (NTS) since 1976, when a document published by Borg et a7. (1976) summarized information pertinent to the migration of radionuclides in ground water at the NTS. In the present study, a literature review was conducted to examine information published since 1976 about the various activities that have occurred at the NTS. Information was collected from the literature on the site's geological, hydrological, geochenical, and geomorphic characteristics related to the impacts on the ground water from weapons testing and the disposal of waste at the NTS. This information was used to identify the state of knowiedge about the NTS and the potential impacts of NTS activities on the ground water. More than 250 reports were reviewed, of which about 200 contained information pertinent to the subject of this report. Because the reports have never been collected in a single location, only those that were supplied by the U.S. Department of Energy and other cooperating organizations could be reviewed, and some pertinent documents may have been missed. Appendix A contains an annotated bibliography of the reports reviewed.

Review of the new literature continues to support the following conclusions of Borg et al. (1976):

- The migration of radionuclides other than tritium to offsite public wells or springs at levels greater than the maximum permissible concentration (MPC; DCG - Derived Concentration Guides) is unlikely.

- Subsurface migration offsite of tritium above MPC levels is possible, but there seems to be a small probability of its appearance in offsite public wells or springs.

- The most likely source of tritium, if it appears offsite, is Pahute Mesa.

- Understanding of the subject of migration of radionuclides at NTS is hampered by a lack of values for fundamental parameters used in transport calculations. 
.

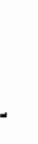




\section{ACKNOWLEDGMENTS}

We would like to thank Marye Hefty for assisting in preparing abstracts for the annotated bibliography, Laurel Grove for editing the report and annotated bibliography, and Suzy Boehning and the Sigma $V$ team for text processing. 


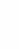




\section{CONTENTS}

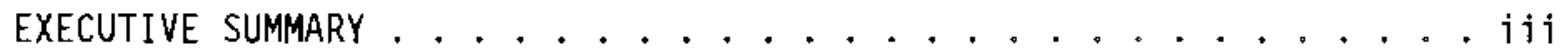

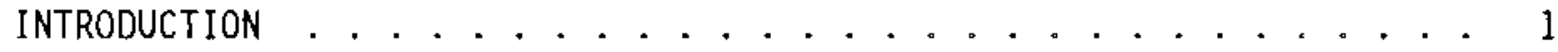

DESCRIPTION OF THE NEVADA TEST SITE .............. 3

GEOLOGY OF THE NEVADA TEST SITE AND VICINITY . . . . . . . . 7

REGIONAL GEOLOGIC SETTING . . . . . . . . . . . 7

GEOLOGIC STUDIES OF BOREHOLES AND TUNNELS . . . . . . . . 12

SPECIAL GEOLOGIC STUDIES . ............... 18

SURFACE WATER HYDROLOGY ..................... 29

MOISTURE TRANSPORT IN THE UNSATURATED ZONE .......... 33

HYDROGEOLOGY OF THE NEVADA TEST SITE AND VICINITY . . . . . . . . 37

ASH MEADOWS GROUND-WATER BASIN . . . . . . . . . . 39

PAHUTE MESA GROUND-WATER SYSTEM . . . . . . . . . . 42

GROUND-WATER MOVEMENT . . . . . . . . . . . . . . . 44

INVESTIGATIONS OF SITE HYDROLOGY SINCE $1976 \ldots \ldots \ldots$

MODELING AND SIMULATION STUDIES SINCE $1976 \ldots \ldots . \ldots$

RADIONUCLIDE MIGRATION IN THE UNDERGROUND ENVIRONMENT $\ldots \ldots . \ldots . .53$

GROUND-WATER QUALITY MONITORING AT AND NEAR THE NTS . . . . . . . 67

REFERENCES ........................... 71

APPENDIX A - ANNOTATED BIBLIOGRAPHY . . . . . . . . . . . . A.I 


\section{FIGURES}

1 Location Maps of the Nevada Test Site . . . . . . . . . . 2

2 Physiographic Diagram of the NTS and Surrounding Areas . . . . 4

3 Index Map of the NTS and Vicinity ............5 5

4 Location of Paleozoic Cordilleran Miogeosyncline in the Western United States and Idealized Features along Continental Margin . . 8

5 Map Showing Pattern of Basin and Range Faults in the NTS and Vicinity ................... 10

6 Schematic Cross Sections Portraying the Geologic Complexity Surrounding Yucca Mountain in Southwestern Nevada and Showing the Style of Faulting and Caldera Complexes .......... 13

7 Distribution of Intrusive Outcrops in the NTS Area ...... 14

8 Distribution of Silicic Tuff and Related Rock Outcrops in the NTS Area .................. 15

9. Distribution of Silicic and Intermediate Composition Lava

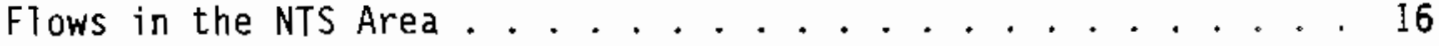

10 Map of the Dominant Features from the Right Rib of the Rock Mechanics Drift ............... 17

11 Seismic Risk Map in the NTS Region ........... 20

12 Fence Diagram Showing Thicknesses of Alluvium and Tuff Members of Paintbrush Tuff in Dri7l Holes at Yucca Mountain . . . . . . 22

13 Timber Mountain-Oasis Valley Caldera Complex ........ 23

14 East-West Geologic Cross Section for UE7NS and UE2CE . . . . 24

15 Location of Candidate Area and Potential Site . . . . . . . 26

16 Geologic Map of the Abandoned Wash Block at Yucca Mountain . . . 28

17 Drainage Basins in the Yucca Mountain Area Showing Direction of Flow of Surface Water............ . . 30

18 Approximate Location of Boundary Between Ash Meadows GroundWater Basin and Pahute Mesa Ground-Water System, NTS . . . . . . 38 
19 Hydrogeologic Map of the NTS and Vicinity. . . . . . . . 43

20 Locations of Experimental Sites Described in This Report . . . . 55

21 Bilby Site Cross Section .............. . 56

22 Cambric Site Cross Section .............. 58

23 Starwort Site Cross Section .............. 60

24 Nash Site Cross Section ............... . 61

25 Bourbon Site Cross Section ............. 63

26 Cheshire Site Cross Section............... 65

27 Map of the NTS and Vicinity Showing the Monthly and Semiannual Ground-Water Quality Monitoring Network . . . . . . . . . 68

28 Location of Water Sampling Sites - Desert Research Institute, $1982 \ldots \ldots \ldots 70$ 


\section{$\underline{\text { TABLES }}$}

1 Chemical Composition of Rocks at the NTS . . . . . . . . . . 11

2 Geohydrologic Units at the NTS ............ 40 


\section{ACRONYMS}

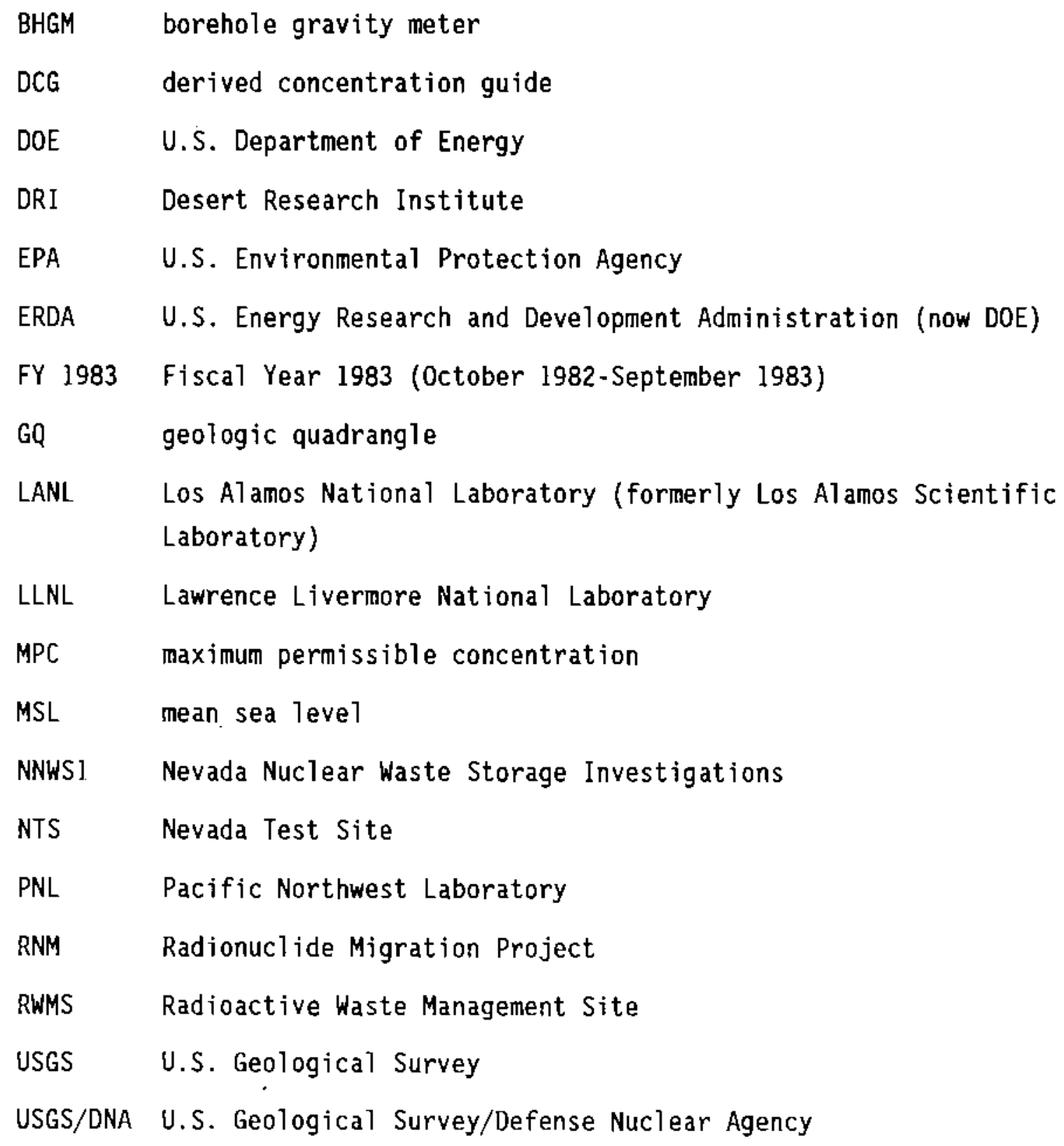




\section{INTRODUCTION}

The Nevada Test Site (NTS) is a U.S. Department of Energy (DOE) facility used primarily for nuclear weapons testing. The NTS is located approximately $75 \mathrm{mi}(120 \mathrm{~km})$ northwest of Las. Vegas, Nevada, and about $235 \mathrm{mi}$ (378 km) northeast of Los Angeles (Fig. 1).

After 30 years of underground testing at the NTS, large quantities of radioactive and nonradioactive material have been released into the subsurface environment at the site by underground tests that have been conducted both below and above the water table. As a result, transport of these materials has occurred, either moving upward through the unsaturated zone into the atmosphere or migrating in ground water within the underlying formations.

Pacific Northwest Laboratory (PNL), under funding from DOE's Nevada Operations office, initiated a study to review published documents on the migration and possible consequence of contaminants in the ground and ground water in and adjacent to the NTS. This is part of an ongoing program to understand radionuclide migration in the subsurface environment at the NTS. The literature review covered reports published at the NTS between 1976 and 1988 , subsequent to the documentation by Borg et al. (1976) that summarized all information pertinent to the migration of radionuclides in ground water at the site. This report represents a compilation of information obtained from more than 250 reports, of which about 200 supplied information pertinent to the area of this study. Because the reports have never been collected in a single location, only those that were supplied by DOE and other cooperating organizations could be reviewed, and some pertinent documents may have been missed. Topics in this report include the site history; the geographic setting, physiography, and climate; site geology; surface-water hydrology; moisture movement in the unsaturated zone; hydrogeology; and radionuclide migration. 

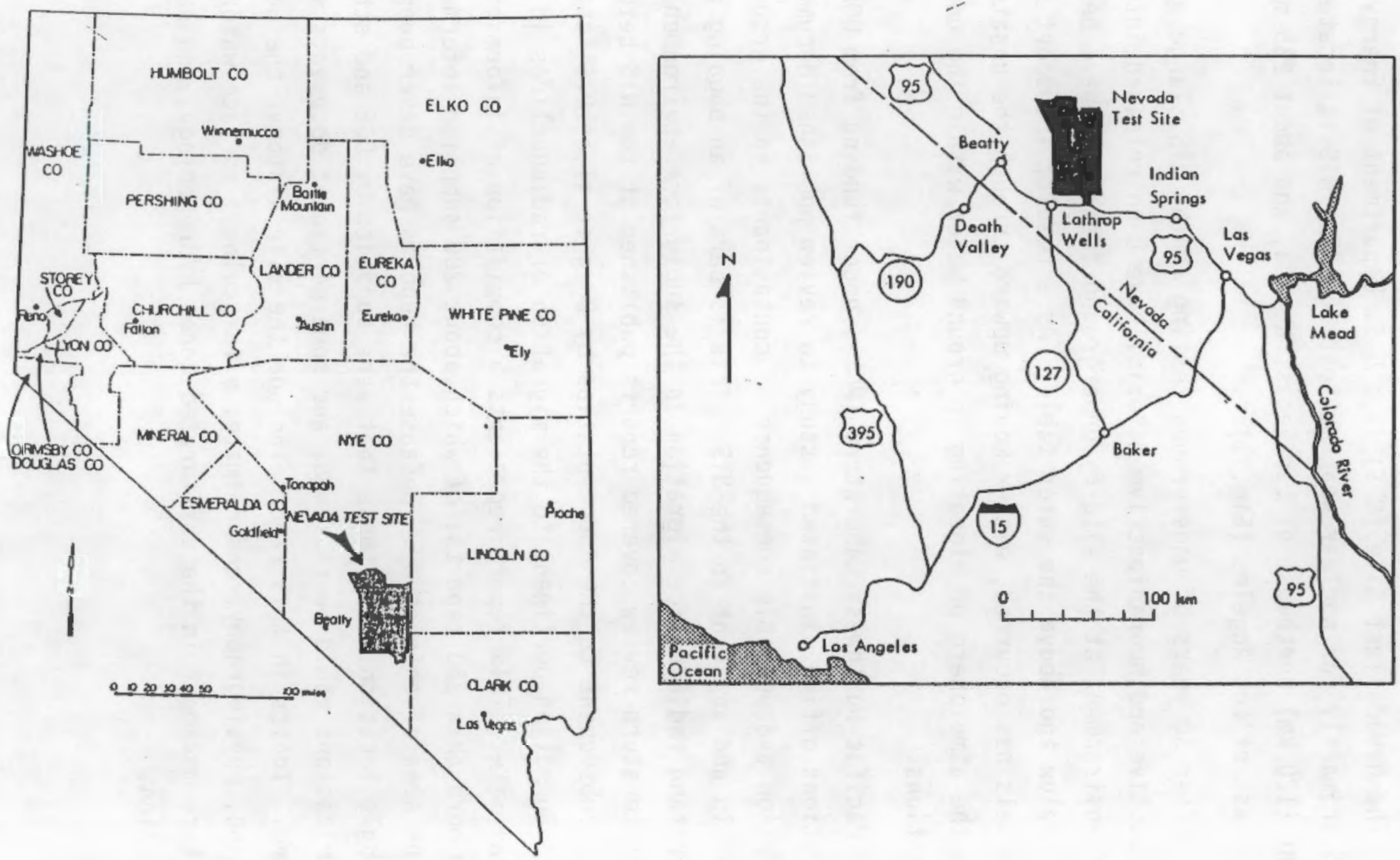

FIGURE 1. Location Maps of the Nevada Test Site 


\section{DESCRIPTION OF THE NEVADA TEST SITE}

The NTS encompasses an area of $1,390 \mathrm{mi}^{2}\left(3,600 \mathrm{~km}^{2}\right)$ and lies within Nye County, in southern Nevada (Fig. 2). Major physiographic features near the NTS are Death Valley to the southwest, Las Vegas Valley to the southeast, Emigrant and Desert Valleys to the northeast, and Sarcobatus and Stonewall Flats to the west and northwest.

The NTS lies in the basin and range physiographic province. The northwestern portion of the NTS consists of broad mesas and several volcanic ranges. The southern portion consists primarily of basins and ranges produced by a combination of normal block faulting, thrust faulting, and intrusions. Elevations in and around the NTS vary from a low of $280 \mathrm{ft}(85 \mathrm{~m})$ below sea level in Death Valley, to $2,790 \mathrm{ft}(850 \mathrm{~m})$ in the Jackass Flats area, to a high of $9,850 \mathrm{ft}(3,000 \mathrm{~m})$ in the Sheep Range. Drainage from the NTS is toward Death Valley (DOE 1986). However, no important perennial or intermittent streams exist, other than flash flood drainage, on the NTS or in the nearby surrounding area.

The NTS lies in the most arid portion of Nevada and receives a mean annual precipitation of 3 to $6 \mathrm{in}$. $(8$ to $16 \mathrm{~cm}$ ) in the valleys to less than 12 in. $(30 \mathrm{~cm})$ in the upland areas (Winograd and Thordarson 1975b). No published temperature data are available for the NTS; however, the mean daily maximum temperature at Las Vegas varies from $32^{\circ} \mathrm{F}\left(13^{\circ} \mathrm{C}\right)$ in January to $105^{\circ} \mathrm{F}$ $\left(40.5^{\circ} \mathrm{C}\right.$ ) in July (Borg et al. 1976). The higher valleys, among which the NTS is included, consistently have temperatures that are lower (Borg et al. 1976).

The NTS was selected as a site for testing nuclear explosives in December 1950. The first announced nuclear test occurred on January 27, 1951, and the first announced underground test occurred on September 19, 1957. From 1951 through December 1987, there were a total of 680 announced nuclear tests. Since July 17, 1962, all nuclear device tests have been detonated underground. Of the total number of announced tests, 105 were aboveground tests (including 84 weapon or weapons-effects tests, 17 safety tests, and 


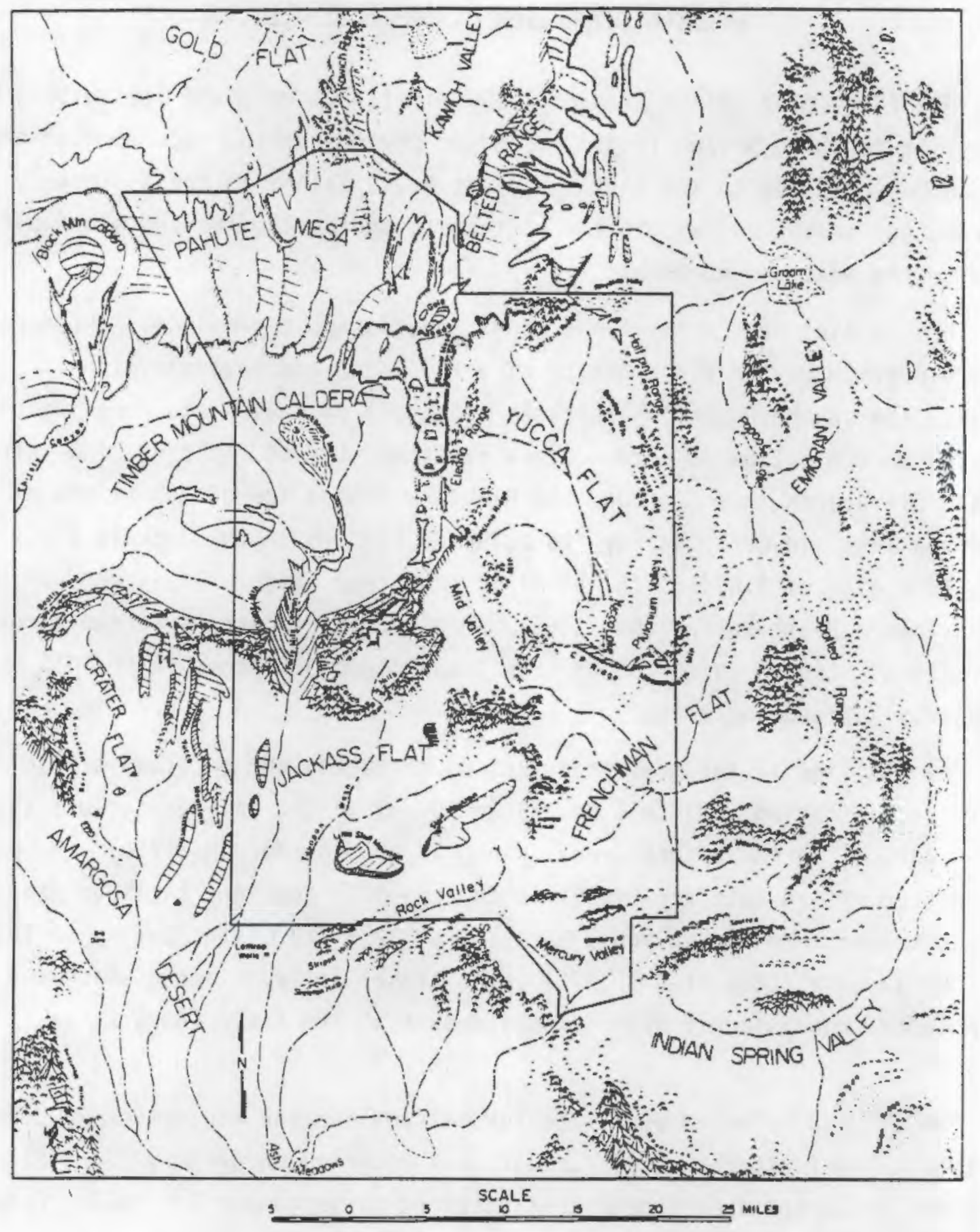

FIGURE 2. Physiographic Diagram of the NTS and Surrounding Areas (after Sinnock 1982) 
4 storage-transportation tests) and 575 were underground tests (including 9 crater, 61 tunnel, and 505 shaft tests). Four major areas were used for detonation of nuclear devices: Yucca Flat, Rainier Mesa, Pahute Mesa, and Frenchman Flat (Fig. 3).

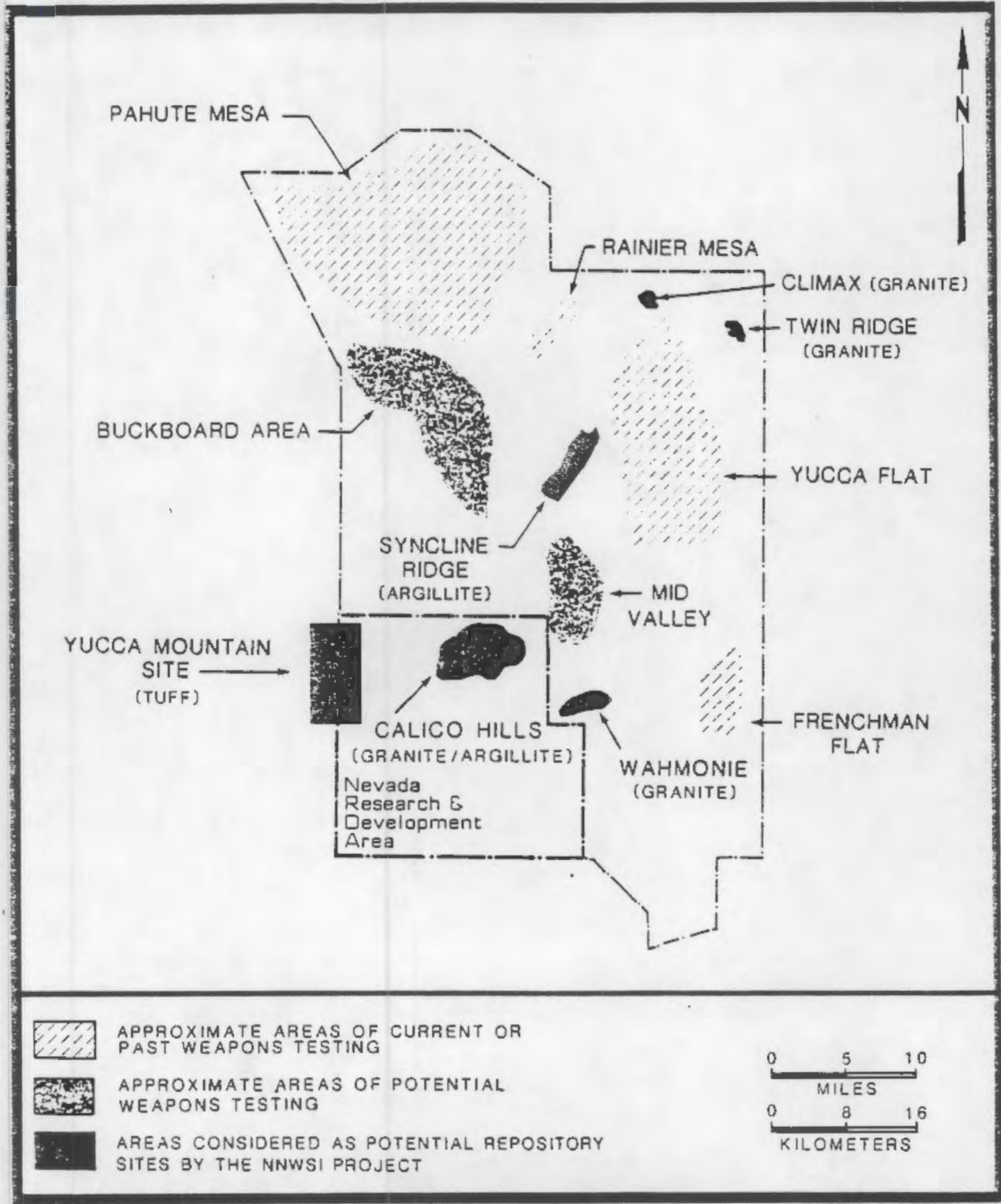

FIGURE 3. Index Map of the NTS and Vicinity (after Winograd and Thordarson 1975a) 



\section{GEOLOGY OF THE NEVADA TEST SITE AND VICINITY}

Numerous investigations conducted at or in the vicinity of the NTS have contributed to the current understanding of the site's geology. The purpose of the following discussion is to provide summaries of past studies and descriptions of recent investigations as they relate to three distinct geologic areas. The first group of studies concerns the regional geologic setting of NTS. The second group of studies is focused on specific geologic investigations at the NTS related to the construction of boreholes and tunnels used in testing of nuclear devices, and the third group includes special geologic studies associated with vertical shaft testing of nuclear devices, the shallow storage of radioactive waste at the NTS, and the siting of a geologic repository for high-level radioactive waste at nearby Yucca Mountain.

\section{REGIONAL GEOLOGIC STUDIES}

The NTS lies in the southern portion of the Great Basin and Range Physiographic Province within the miogeosynclinal belt of the Cordilleran geosyncline (Fig. 4). Rocks present in this area can be divided into four groups. The oldest rocks are gneiss and granite, which make up part of the crystalline shield of the North American continent. Above the shield rocks are more than $40,000 \mathrm{ft}(12,200 \mathrm{~m})$ of marine carbonate and clastic rocks consisting of carbonates, quartzite, shale, and argillite, deposited during the late Precambrian and Paleozoic eras. For about 100 to 250 million years, these rocks were subjected to deformations and faulting that formed the early mountains. The third group of rocks includes granitic masses intruded into the sediments during the Mesozoic Era (Stewart and Carlson 1978). Granitic outcrops can be found in the northern part of the NTS. The last group includes extensive amounts of rhyolitic and quartz-latitic ash-flow tuffs and ash-fall tuffs and rhyolites deposited by Tertiary volcanism (Borg et al. 1976). These volcanic rocks range from several hundred feet to more than $13,000 \mathrm{ft}(4,000 \mathrm{~m})$ thick. 

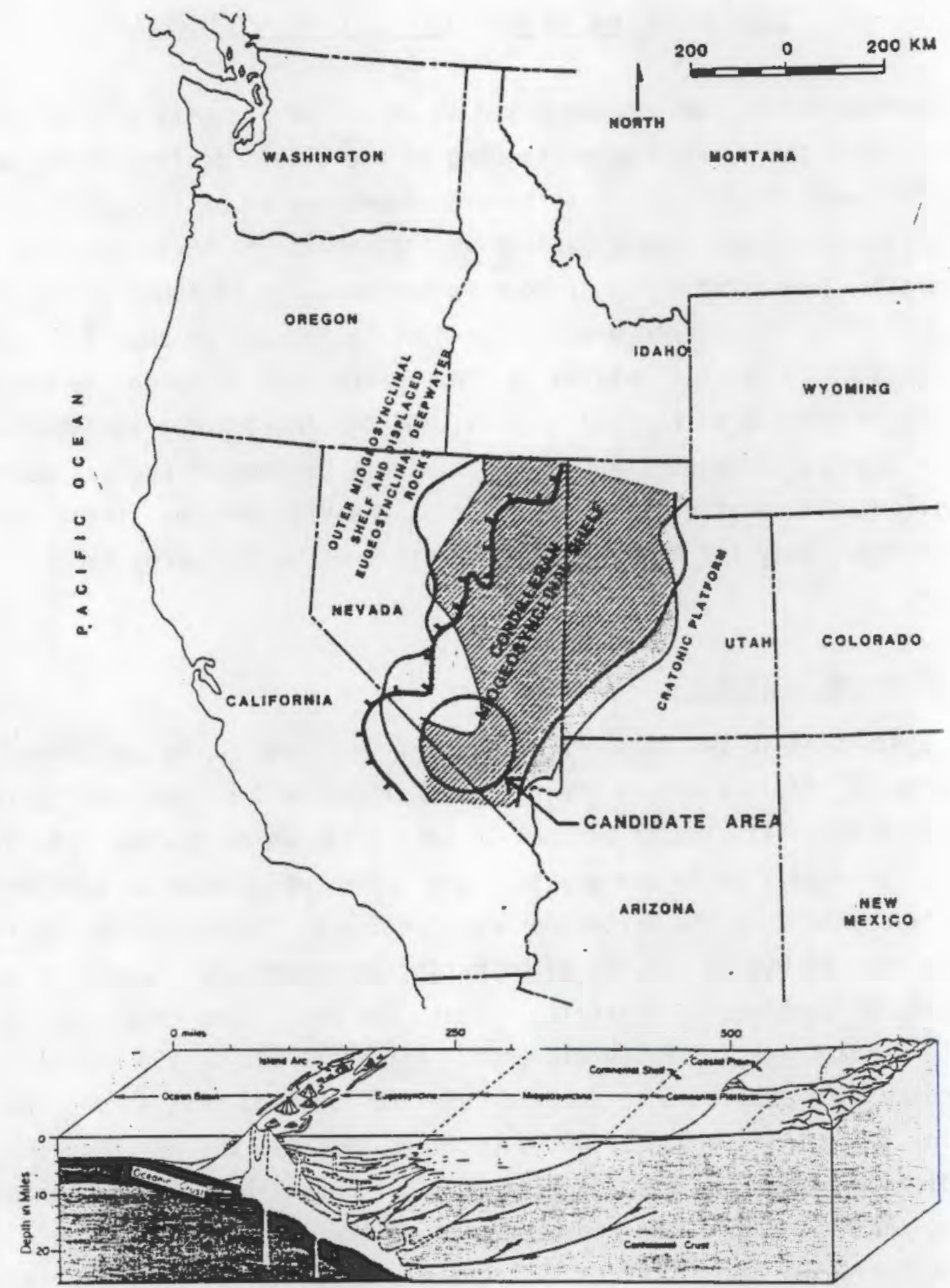

FIGURE 4. Location of Paleozoic Cordilleran Miogeosyncline in the Western United States (from USGS 1983b) and Idealized Features along Continental Margin (after Sinnock 1982) 
During the Mesozoic era, the region was subjected to two periods of crustal deformation. During the late Mesozoic era, the Sevier Orogeny caused folding and thrust faulting to occur in the Precambrian and Paleozoic rocks (Sinnock 1982) (Fig. 5). The displacement along major thrust faults ranged from a few meters to thousands of meters. During the late and middle Cenozoic era, normal faulting occurred along a north-south trend that was superimposed on the earlier structures (Borg et al. 1976). The normal type faults, which are on the flanks of basins, have movement in excess of hundreds of meters. A major structure associated with this faulting is the Walker Lane - Las Vegas shear zone (Longwell 1960). This shear zone extends from the Las Vegas Valley northwestward to the vicinity of Mercury, Nevada. The Las Vegas shear zone has right-lateral movement in excess of $130,000 \mathrm{ft}$ $(40,000 \mathrm{~m})$ (Ekren et al. 1968).

During the upper Tertiary and Quaternary periods, alluvial and lacustrine deposits filled most of the valleys and depressions at the NTS. The thickness of these deposits varies from a few hundred feet to over $3,000 \mathrm{ft}$ $(1,000 \mathrm{~m})$. As a result of sedimentation and subsequent folding, faulting, and erosion, about $30 \%$ of the site contains alluvial filled valleys. The remainder of the site consists of Paleozoic and upper Precambrian rock outcrops and volcanic rocks (USGS 1983a).

The rock types found at the NTS are highly diverse (Barnes, Christiansen, and Byers 1965). As described by Borg et al. (1976), the rock types vary from unconsolidated playa sediments to quartzite, grandiorite, marbles, tuff, and basalt. Table 1 describes the chemical and mineralogical makeup of the various rock types found at the NTS. According to Ramspott and Howard (1975), there is considerable variability, not only in the physical properties (density, porosity, etc.) of rock types from place to place, but in their chemical and mineralogical components as well.

Since 1976, two other documents have described the regional geology of the NTS. Work by the Sandia National Laboratory (Sinnock 1982) presents an overall description of the geology of consolidated and unconsolidated materials, structural features, and tectonics at the NTS. The document contains 

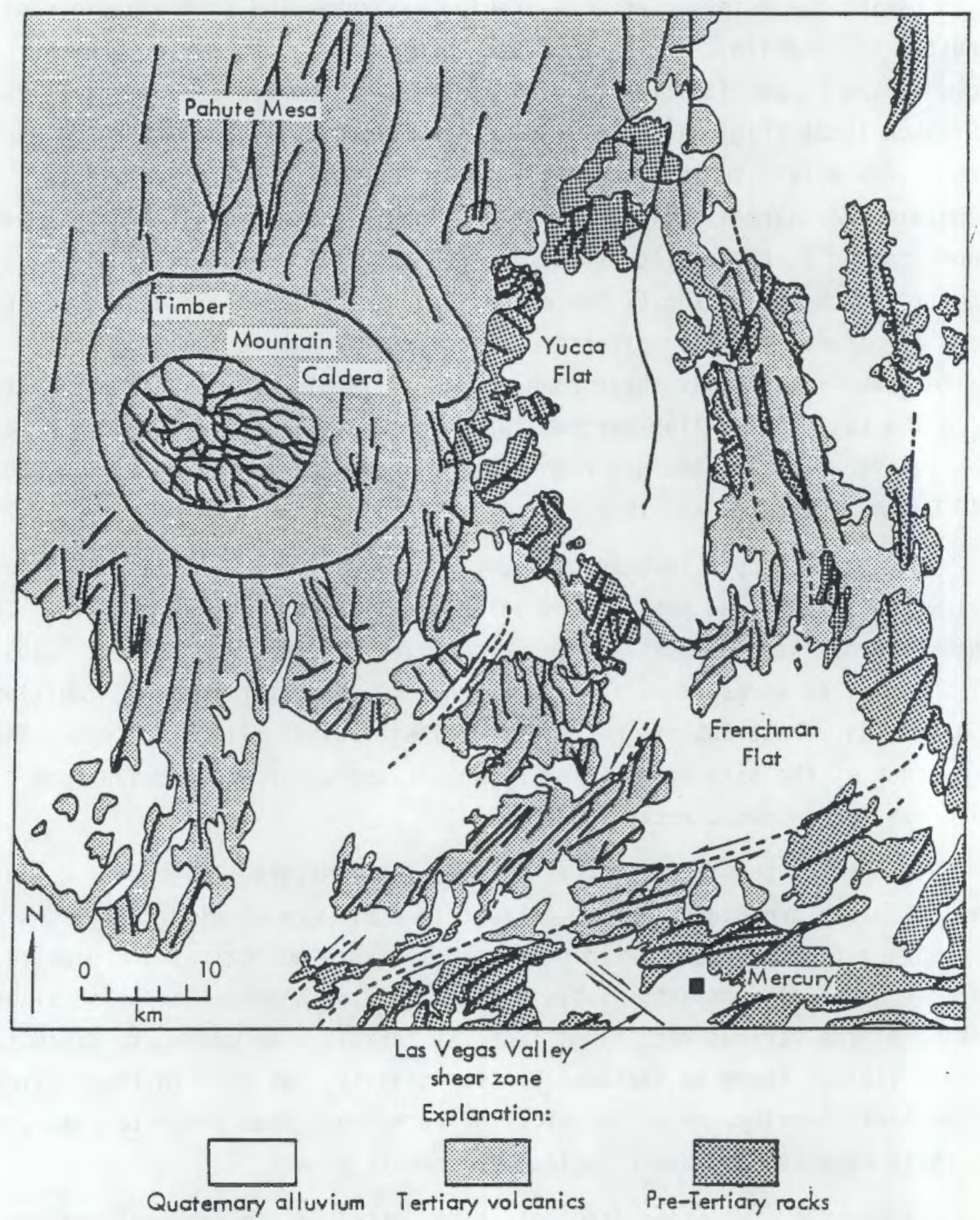

FIGURE 5. Map Showing Pattern of Basin and Range Faults in the NTS and Vicinity (after Ekren et a1. 1968) 
TABLE 1. Chemical Composition of Rocks at the NTS (after Borg et al. 1976)

\begin{tabular}{|c|c|c|c|c|c|c|c|}
\hline & $\begin{array}{l}\text { Alluvium, } \\
\text { U3ah, } \\
1,197-1,204 \mathrm{ft} \\
(365-367 \mathrm{~m}) \\
\end{array}$ & $\begin{array}{l}\text { Welded Tuff, } \\
\text { Oak Springs } \\
\text { Tuff } \\
\text { Unit Tos } \\
\text { (Rainier) } \\
\end{array}$ & $\begin{array}{l}\text { Zeol itized } \\
\text { Tuff, Ue15d, } \\
1,069 \mathrm{ft}(326 \mathrm{~m}) \\
\end{array}$ & $\begin{array}{c}\text { Dolomite } \\
\text { (Handcar) } \\
\text { u10b, } 1,342 \mathrm{ft} \\
(\sim 409 \mathrm{~m}) \\
\end{array}$ & $\begin{array}{l}\text { Climax } \\
\text { grano- } \\
\text { diorite, } \\
\text { U15a } \\
\end{array}$ & $\begin{array}{c}\text { Altered } \\
\text { Andesite } \\
\text { (Cannikin), } \\
\text { UA-1,5,874 ft } \\
\left(1,791^{\mathrm{m})}\right. \\
\end{array}$ & $\begin{array}{c}\text { Basalt, } \\
\text { Chukar Mesa } \\
\text { (Buggy), } \\
66-2 \\
\end{array}$ \\
\hline $\mathrm{SiO}_{2}$ & 65.8 & 75.5 & 66.6 & 0.89 & 67.5 & 48.9 & 56.66 \\
\hline $\mathrm{Al}_{2} \mathrm{O}_{3}$ & 14.1 & 13.9 & 13.2 & 0.40 & 16.2 & 14.5 & 10.75 \\
\hline $\mathrm{TiO}_{2}$ & 0.39 & 0.20 & 0.18 & nd & 0.46 & 1.1 & 1.25 \\
\hline $\mathrm{Fe}_{2} \mathrm{O}_{3}$ & 2.1 & 1.43 & 1.5 & 0.13 & 1.9 & 3.6 & $1.71^{a}$ \\
\hline Feo & 0.49 & 0.13 & 0.05 & 0.04 & 1.7 & 7.5 & 4.26 \\
\hline Mgo & 1.5 & 1.0 & 0.47 & 21.21 & 0.7 & 5.7 & 0.27 \\
\hline Mno & 0.07 & nd & 0.05 & nd & 0.07 & 0.15 & 0.18 \\
\hline ఐ $\mathrm{CaO}$ & 2.4 & 2.0 & 1.8 & 30.96 & 3.9 & 8.3 & 4.72 \\
\hline $\mathrm{Na}_{2} \mathrm{O}$ & 2.1 & 1.9 & 1.5 & nd & 3.2 & 4.3 & 10.51 \\
\hline $\mathrm{K}_{2} \mathrm{O}$ & 3.6 & 2.8 & 5.0 & nd & 3.4 & 0.95 & 6.37 \\
\hline $\left.\mathrm{H}_{2} \mathrm{O}+230^{\circ} \mathrm{F}\left(110^{\circ} \mathrm{C}\right)\right\}$ & 6.3 & nd & 9.8 & nd & 0.83 & 2.2 & 2.00 \\
\hline $\left.\mathrm{H}_{2} \mathrm{O}-230^{\circ} \mathrm{F}\left(110^{\circ} \mathrm{C}\right)\right]$ & & 0 & & 0.08 & 0 & 0.64 & \\
\hline $\mathrm{CO}_{2}$ & 0.73 & nd & 0.06 & 46.18 & 0.18 & 0.82 & nd \\
\hline $\mathrm{P}_{2} \mathrm{O}_{5}$ & 0.12 & 0.08 & 0.02 & nd & 0.18 & nd & 0.64 \\
\hline$F+C l$ & nd & nd & nd & nd & nd & nd & 0.09 \\
\hline$S r+s$ & nd & nd & nd & nd & nd & nd & 0.33 \\
\hline Reference & $\begin{array}{l}\text { Emerick } \\
\text { (1961) }\end{array}$ & $\begin{array}{l}\text { Sorg } \\
(1975)\end{array}$ & $\begin{array}{l}\text { Williams } \\
\text { et al. (1963) }\end{array}$ & $\begin{array}{l}\text { Smith } \\
(1970)\end{array}$ & $\begin{array}{l}\text { Gibbons } \\
\text { al. (1959) }\end{array}$ & $\begin{array}{l}\text { Gard } \\
(1972)\end{array}$ & $\begin{array}{l}\text { J. Hill, } \\
\text { analyst (LLNL) }\end{array}$ \\
\hline
\end{tabular}

${ }^{a} \mathrm{FeO}_{\mathrm{Fe}} \mathrm{O}_{3}$ ratio arbitrarily set at 2.50 for partitioning of Fe reported in analysis. 
an idealized cross section of portions of the NTS (Fig. 6) and illustrates the distribution of various types of rock outcrops (Figs. 7 through 9). A report by Orkild (1981), the result of a paper given at a containment symposium in Monterey, California, August 26-28, 1981, contains similar information. Although this document was not published by the U.S. Geological Survey (USGS), it was included in a symposium volume published by Los Alamos National Laboratory (LANL).

\section{GEOLOGIC STUDIES OF BOREHOLES AND TUNNELS}

A significant amount of geologic data has been collected at the NTS as part of nuclear testing programs that have made use of tunnels and horizontal shafts. A total of 61 nuclear detonations have been conducted in these programs. The data were collected before each test as a means of understanding the pre-test geologic and hydrologic conditions. The following discussion presents summaries of reports done since 1976.

A variety of geologic information obtained about the tunnels, drifts, and horizontal and vertical holes related to additional tunnel construction has been published. The geology and hydrology of tunnels and drifts at Rainier Mesa have been addressed in documents by Fairer et al. (1979); USGS (1978); Ege, Danilchik, and Feazel (1980); Ege et al. (1980); Townsend et al. (1982); Carroll and Kibler (1983); and Langkopf and Eshom (1982). These documents provide numerous details of tunnel geology and show contacts of geologic units, faults, and rock zones that produce water (Fig. 10). Additional information on stress-relief/borehole-deformation, hydraulic fracturing, geophysics, post-test observations (rock slabbing, support problems, ravelly ground, and water inflow along fractures), and geophysical properties of various rock types has been collected by Langkopf and Eshom (1982).

These documents also contain geologic and hydrologic data about vertical holes that were drilled in conjunction with the tunnel construction. The data were used to determine the various lithologic units that overlie the tunnel complexes. Maldonado, Steele, and Townsend (1979) documented the lithologic logs of vertical drill holes constructed on the Rainier and 


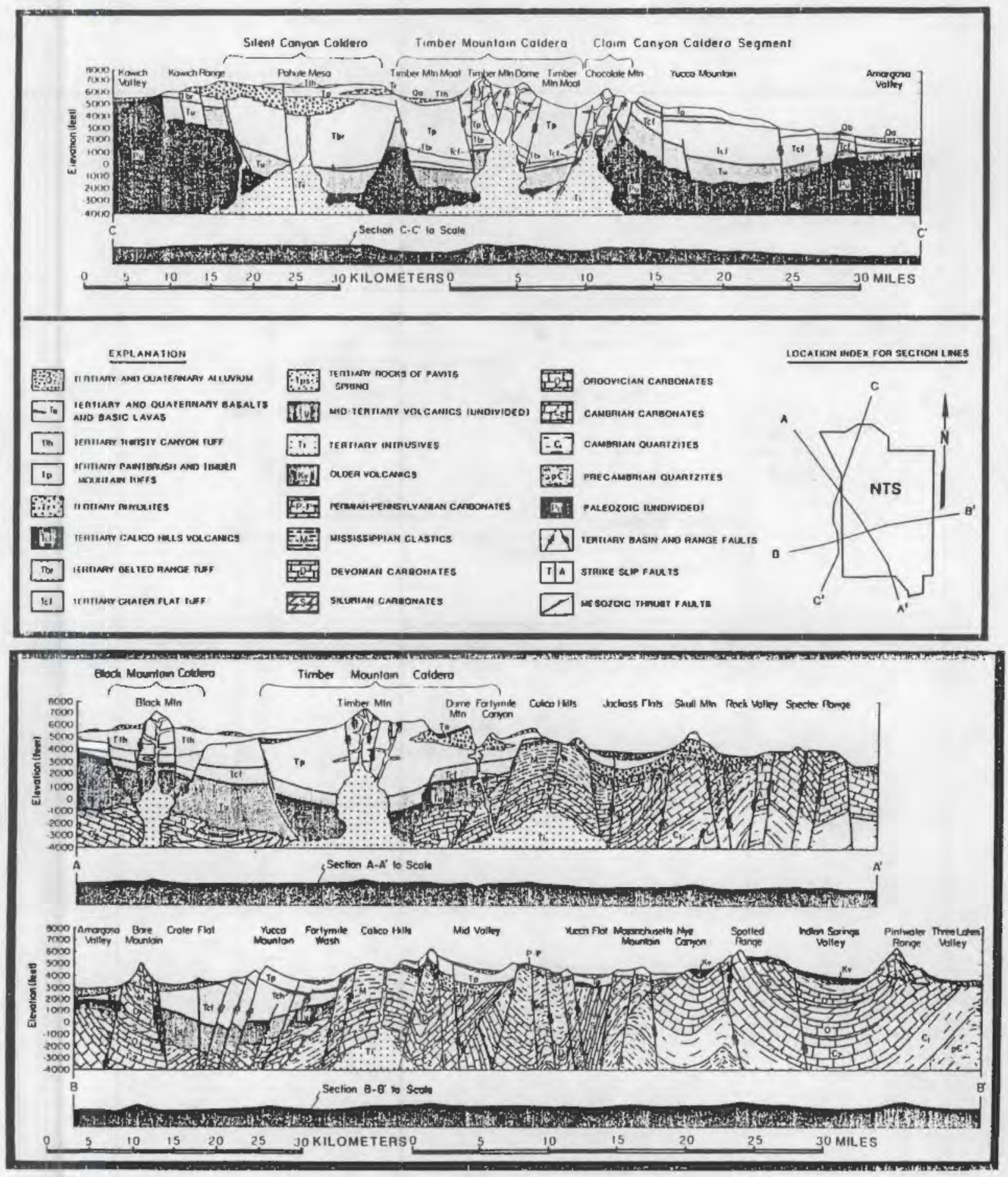

FIGURE 6. Schematic Cross Sections Portraying the Geologic Complexity Surrounding Yucca Mountain in Southwestern Nevada and Showing the Style of Faulting and Caldera Complexes (modified from Sinnock 1982) 


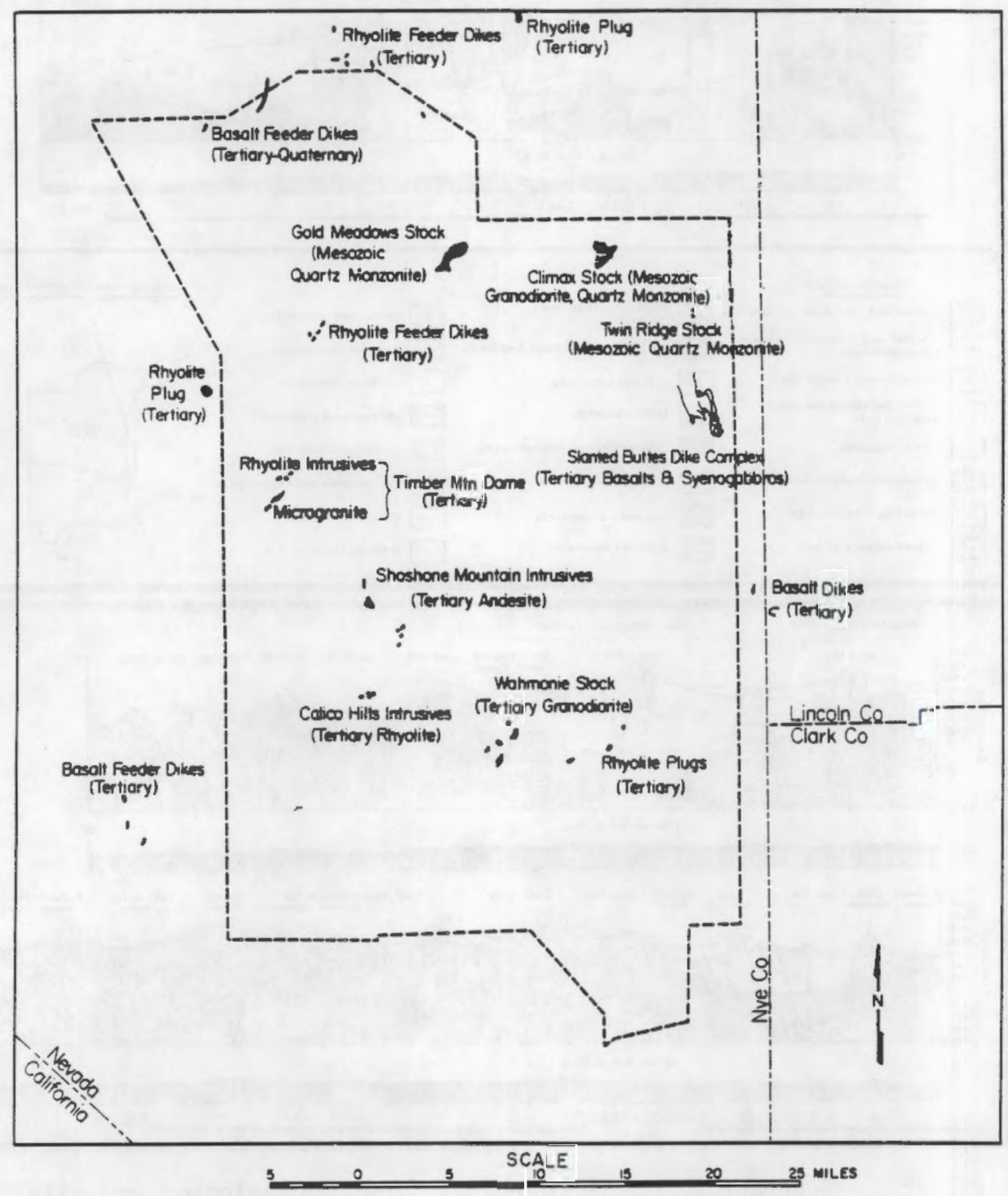

FIGURE 7. Distribution of Intrusive Outcrops in the NTS Area (after Cornwall 1972; Tschanz and Pampeyan 1970; Longwell, Pampeyan, and Bowyer 1965; and USGS Geologic Quadrangle (GQ) Map Series of the NTS Region) 


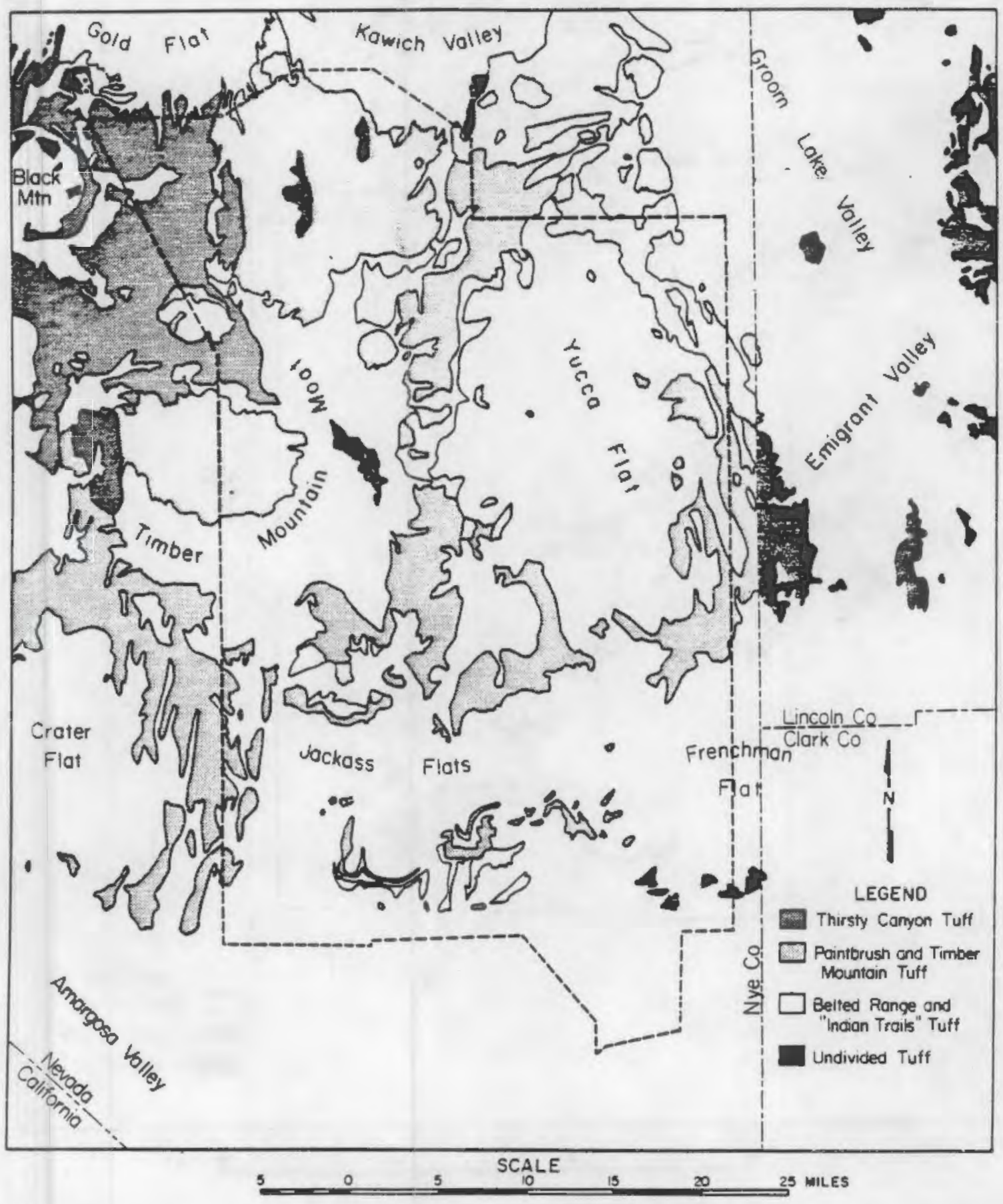

FIGURE 8. Distribution of Silicic Tuff and Related Rock Outcrops in the NTS Area (after Cornwall 1972; Tschanz and Pampeyan 1970, Longwel1, Pampeyan, and Bowyer 1965; and USGS Geologic Quadrangie (GQ) Map Series of the NTS Region) 


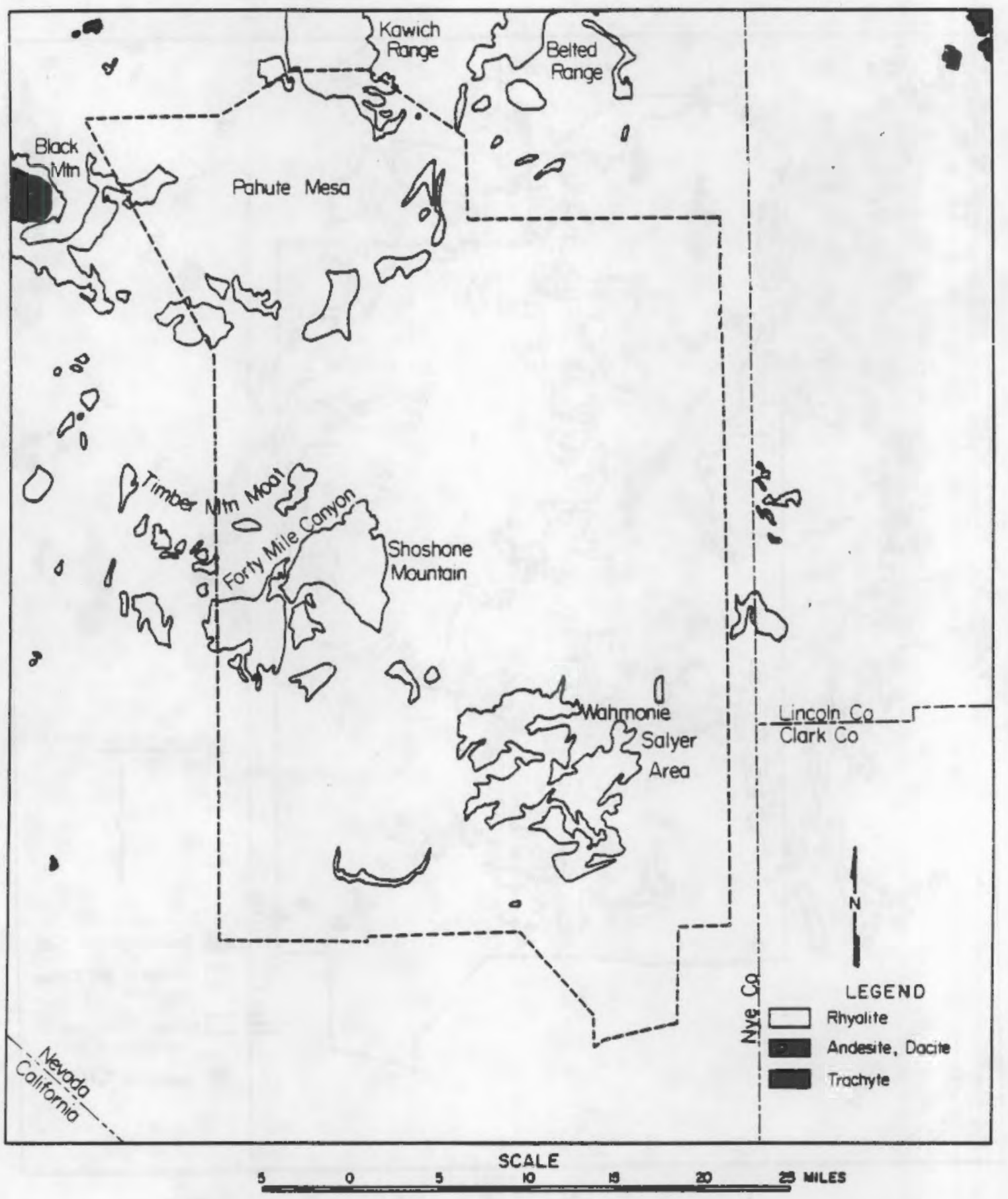

FIGURE 9. Distribution of Silicic and Intermediate Composition Lava Flows in the NTS Area (after Cornwall 1972; Tschanz and Pampeyan 1970; Longwe11, Pampeyan, and Bowyer 1965; and USGS Geologic Quadrangle (GQ) Map Series of the NTS Region) 


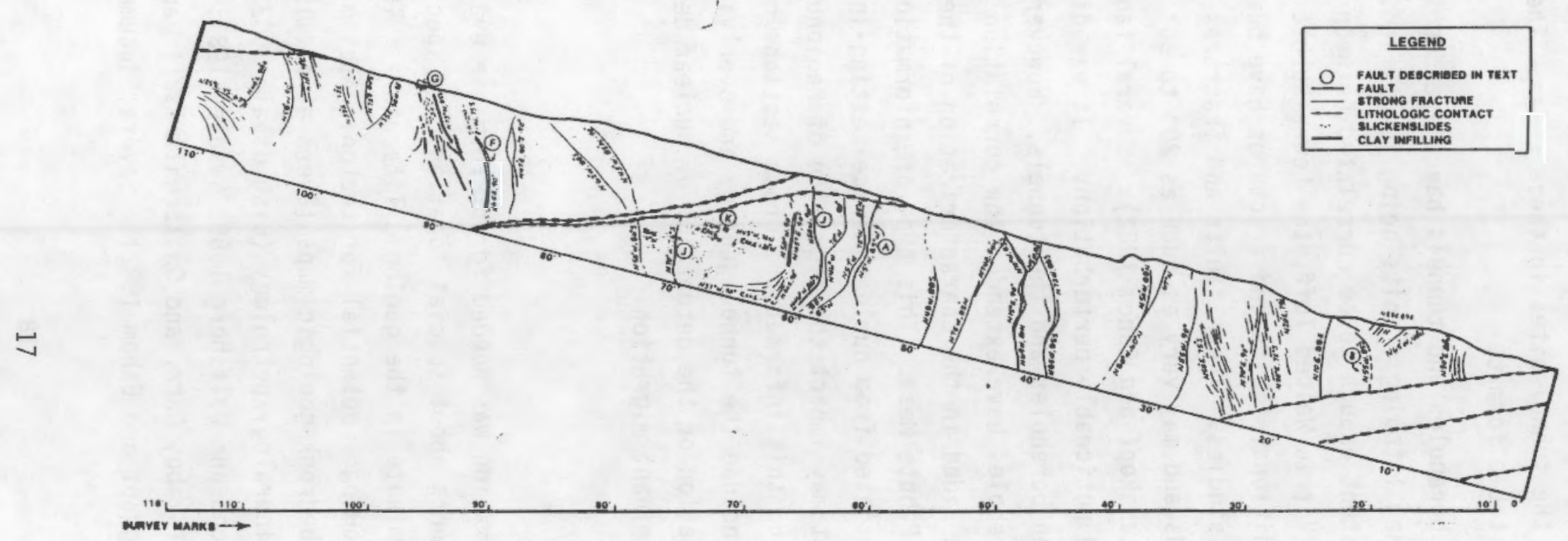

FIGURE 10. Map of the Dominant Features (Fractures and Faults) from the Right Rib of the Rock Mechanics Drift. Drift orientation is $\mathrm{N} 35^{\circ} \mathrm{W}$ (after Langkopf and Eshom 1982). 
Aqueduct Mesas. These wells were apparently drilled to determine the lithology in and around the tunnel sites in these areas. The lithologic data are presented in a table format.

Geologic data from boreholes and tunnels have expanded the knowledge of the tuff, with several new lithologic units being identified. Three of these units are areally consistent enough to be correlated between boreholes at the NTS. These include the Vitric Welded Tuff, the Lower Rubble Zone, and the Upper Transitions. Additional faults and fractures have been identified by the borehole and tunnel studies. These faults and fractures show little consistency in the trends and may vary as much as $20^{\circ}$ to $30^{\circ}$ in strike and as much as $20^{\circ}$ in dip (Langkopf and Eshom 1982). Several faults were mapped, of which only two showed noticeable perturbations. It was difficult to correlate any faults between boreholes and the tunnels. However, data obtained from the tunnels and boreholes have extended the correlation of stratigraphic units southward and have aided in the characterization of the Yucca Mountain area, Rainier Mesa, and Pahute Mesa. This type of information allows natural phenomena to be differentiated from nuclear-device-testing-induced changes in rock characteristics that may impact the migration of radionuclides from the detonation site. By using this information, cross sections can be constructed that not only include the tunnel geology and overlying rock units, but also present the location of the detonation of nuclear devices and possible pathways for contaminant migration.

\section{SPECIAL GEOLOGIC STUDIES}

As additional information was needed for performance evaluation of the underground tests, documents about special locations and specific geologic situations came to predominate in the geologic literature. The topics covered include the following: potential for tectonic, seismic, and volcanic events (Metcalf 1983a); bedrock geologic maps (Byers et al. 1976a; Swadley 1983; Maldonado 1984); mineralogy-petrology (Bish et al. 1982); geochemical characterization (Johnstone and Wolfsberg 1980; Swadley 1983; Quinlivan and Byers 1977); age dating (Szabo, Carr, and Gottschall 1981); and faults, both natural and manmade (Langkopf and Eshom 1982). Several documents address the 
various surface geophysical tools and methods used to investigate geology (Healey, Clutsom, and Glover 1984; Spengler, Muller, and Livermore 1979; Maldonado, Muller, and Morrison 1979). The methods involve such things as magnetometric resistivity, gravity, and magnetic measurements. In addition, several downhole methods of studying geophysics have been used, including sonic velocity logs, density logs, caliper logs, electrical logs, conductivity logs, spontaneous potential logs, gamma logs, and neutron logs (Daniels, Scott, and Hagstrum 1981; Muller and Kibler 1983).

Many documents containing surface and downhole geophysical information are not directly related to the NTS nuclear testing program and consequently were not written specifically to meet its needs. For instance, a number of documents have been written to characterize Yucca Mountain, a candidate site for the disposal of high-level radioactive waste. Although not written for this purpose, these documents do contain information that can be interpolated to the testing area and they therefore are of value and have been included in this review.

Metcalf (1983a) reviewed and summarized the potential for tectonic, seismic, and volcanic activity at Frenchman Flat, which contains a radioactive-waste disposal site. Metcalf's report includes a comprehensive list of references and an annotated bibliography. The report states that Frenchman Flat appears to be in an area of low to moderate seismic hazard (Fig. 11), and that the potential for a large-magnitude earthquake and large peak ground accelerations is low. The Metcalf report also states that fault zones adjacent to the NTS should be considered potentially active and therefore should be considered in any characterization of Frenchman Flat. Metcalf concluded that a site-specific seismic hazard assessment should be conducted for the Frenchman $\mathrm{Flat}$ radioactive-waste disposal site. A second item addressed in the Metcalf report is the hazard from volcanic eruptions. Metcalf concluded that the probability for a volcanic disruption hazard of $1 \times 10^{-8}$ to $1 \times 10^{-9}$ per year that was calculated for the Yucca Mountain area is probably also representative of the hazard at Frenchman Flat. This probability is extremely low, but because of its tectonic setting, Frenchman Flat may be subject to future basaltic volcanism. The document concludes by 


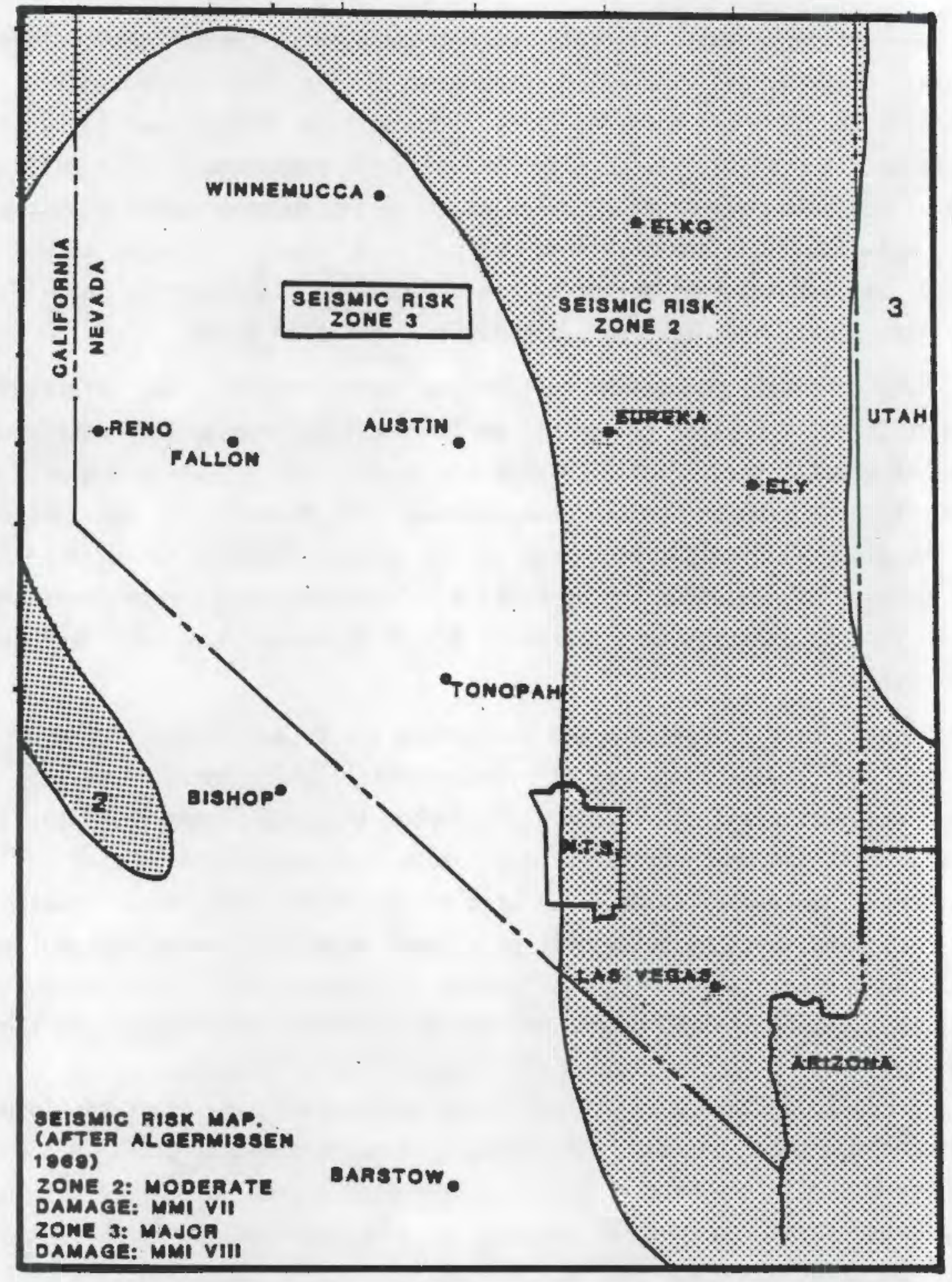

FIGURE 11. Seismic Risk Map in the NTS Region (after Metcalf 1983a) 
recommending that results from ongoing volcanism studies by the USGS and LANL pertinent to Frenchman $\mathrm{Flat}$ be used for assessing volcanic risk for the Frenchman Flat waste-disposal site.

Spengler and Rosenbaum (1980) presented a fence diagram showing the thicknesses of the alluvium and tuff members in the Jackass Flats area (Fig. 12). The stratigraphic correlations were based on interpretations of geologic results obtained from boreholes UE25a-4, $-5,-6$, and -7 . The wells were drilled in 1979, primarily to verify surface electrical surveys that indicated a broad zone of faulting, fracturing, and/or brecciation. The surface features (i.e., washes and ridges) tended to support the hypothesis. If such a zone existed, it would impact the use of Yucca Mountain as a highlevel nuclear waste repository. As a result of this work, it was determined that there were faults in the Jackass Flats area; however, vertical or horizontal displacement was 1 imited or absent, and only limited rotation was found. This small-scale rotation may represent an adjustment to a regional structure that could impact the entire NTS (Spengler and Rosenbaum 1980).

Other documents address the areas of the NTS where testing has taken place or where testing is planned. A document by Byers and Hawkins (1981) includes drill hole information, stratigraphic cross sections, and a watertable map superimposed on a geologic map of the Tertiary units where further testing is planned in the Timber Mountain Caldera Moat (Fig. 13). The geologic information gained from the drill holes allowed for the prediction of the depths of the various geologic units at Timber Mountain Caldera Moat.

Two documents from Lawrence Livermore National Laboratory (LLNL), one by Pawloski (1981) and the other by Wagoner and Ramspott (1981), illustrate cross sections showing stratigraphy and the static water levels in the Yucca Flat area. Additional wells, east and south of the new wells, although not penetrating to the water table, aid in demonstrating that the water table is at some depth greater than the well depths. The stratigraphic cross sections show faults that have substantial vertical offset (Fig. 14a and 14b).

A report by the USGS (1983) is an in-depth discussion of investigations in the Yucca Mountain area at three spatial scales. The first scale is that 


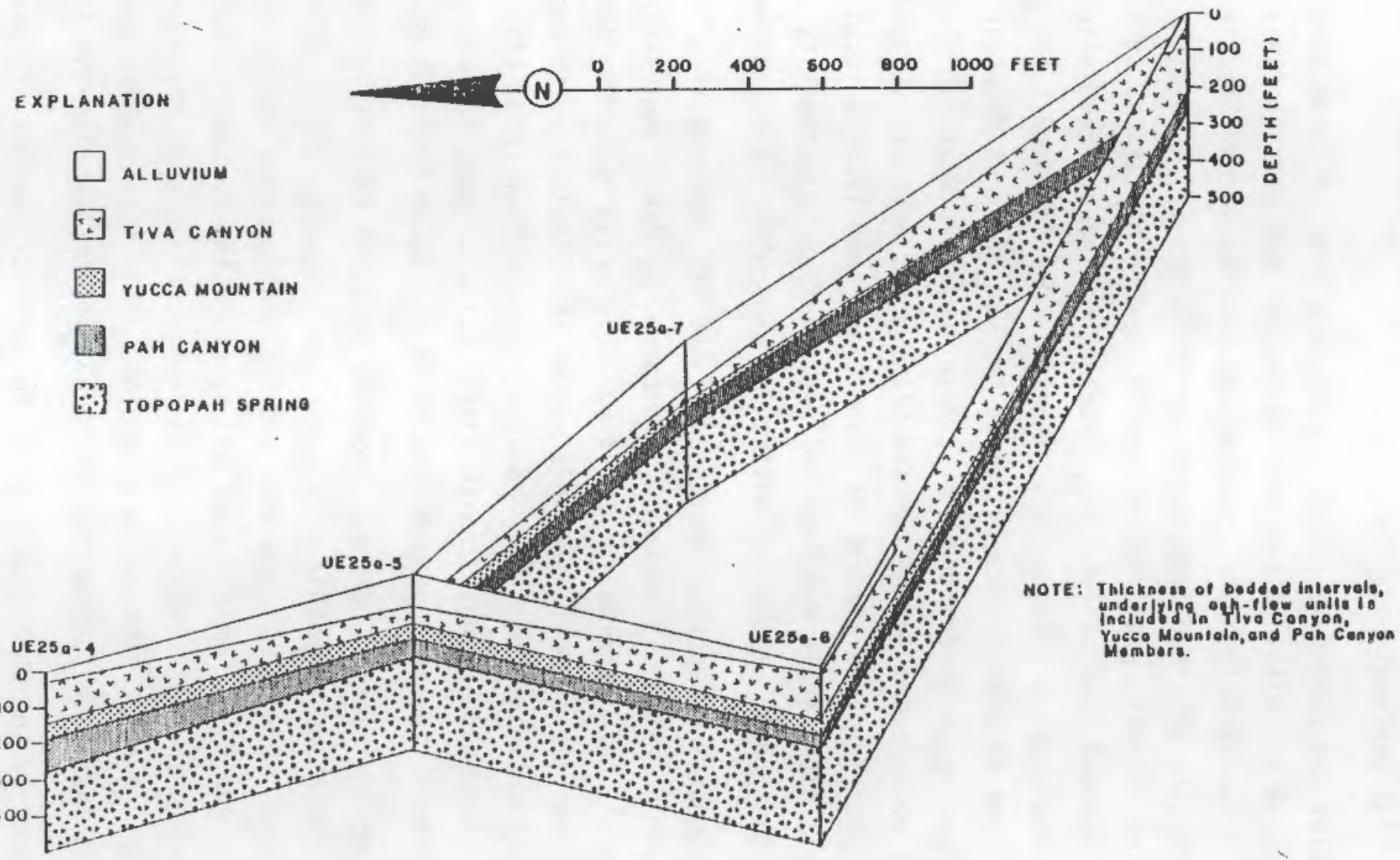

FIGURE 12. Fence Diagram Showing Thicknesses of Alluvium and Tuff Members of Paintbrush Tuff in Drill Holes at Yucca Mountain (after Spengler and Rosenbaum 1980) 


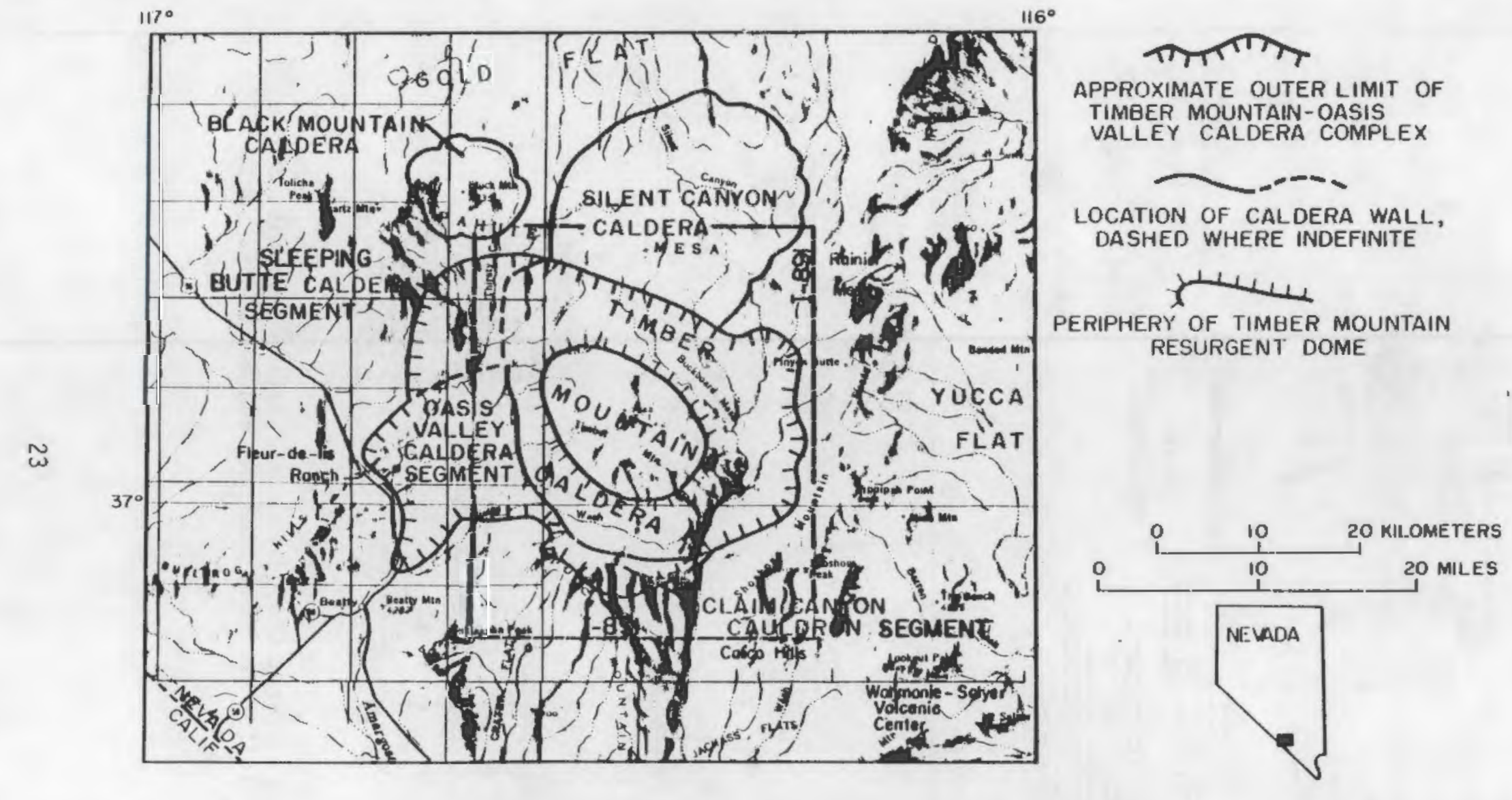

FIGURE 13. Timber Mountain-0as is Valley Caldera Complex. Heavy dashed rectangle encloses area of U.S. Geological Survey map I-89] (Byers et al. 1976a) 

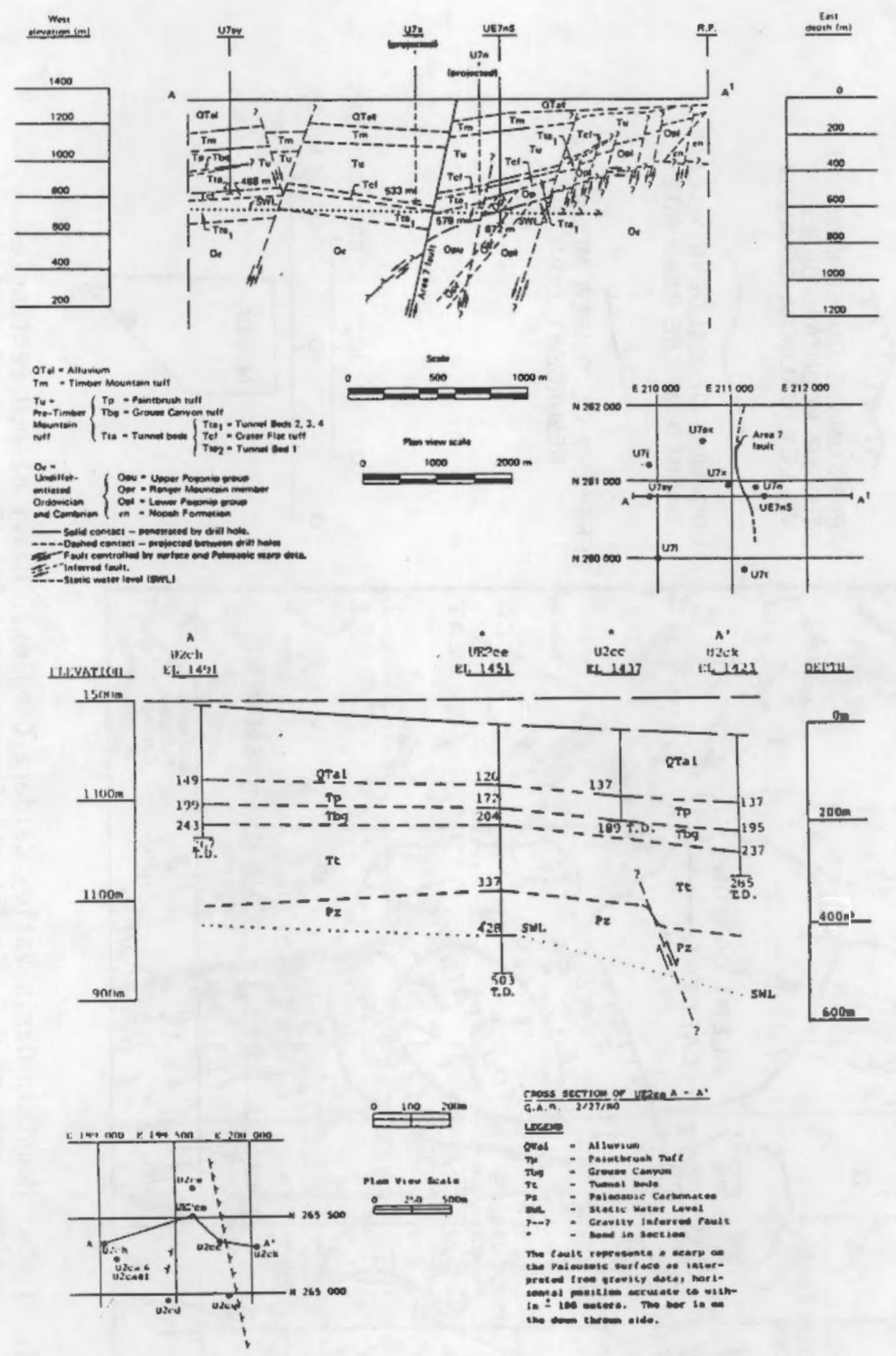

FIGURE 14. East-West Geologic Cross Section for UE7NS and UE2CE (after Pawloski 1982 and Wagoner and Ramspott 1981) 
of the candidate area, which includes everything within a $62-\mathrm{mi}(100-\mathrm{km})$ radius of Yucca Mountain. The second area covers just the repository site and includes approximately the southwest third of the NTS. The final area is site-specific and covers only the central portion of Yucca Mountain. A brief discussion of each of the areas follows.

Investigations at the scale of the entire candidate area (Fig. 15) have been extensive and include geologic mapping of Nevada (Stewart and Carison 1978) and California (Jennings 1977), a large-scale index of geologic mapping (Fouty 1984), aeromagnetic maps of Nevada (Zietz, Gilbert, and Kirby 1978), and isostatic residual gravity mapping (Bracken and Kane 1983). In addition to the investigations of the Cordilleran miogeocline published before 1976 , new information has been obtained on the gneiss and schist intrusives in the Death Valley area and similar outcroppings in the Bullfrog and Trappman Hills (Stewart and Carlson 1978). Stewart and Carlson (1978) also indicated that the only shallow marine and nonmarine rocks of Mesozoic age outcrop in the Spring Mountains. Elsewhere the rock has been removed by erosion. Stewart, Moore, and Zietz (1977) supported earlier findings that there are no deposits of early Tertiary age rock in the candidate area. When volcanism began in northeastern Nevada, large volumes of rhyolitic ash flows and lavas erupted intermittently from coalesced calderas in and near the northern part of the candidate area (Byers et a1. 1976b; Christiansen et a1. 1977). Scattered basaltic scoria cones and lava flows of Quaternary age were found in the central part of the candidate area (Crowe and Carr 1980). The candidate area's PIiocene and Quaternary history has been interpreted by Hoover, Swadley, and Gordon (1981).

Several additional reports that have been published since 1976 contain information relevant to the NTS. New gravity data suggest that pre-Cenozoic rocks are at least $2 \mathrm{mi}(3 \mathrm{~km})$ below the surface under much of the site (Snyder and Carr 1982). Aeromagnetic data reported by Bath and Jahren (1984) suggest that the subvolcanic basement may contain granitic rocks and provide heat for metamorphism. Work by Byers et a1. (1976b); Spengler, Muller, and Livermore (1979); Spengler, Byers, and Warner (1981); Spengler and Rosenbaum (1980); Maldonado and Koether (1983); Scott and Castellanos (1984); Spengler et al. (1981); and Rush, Thordarson, and Bruckheimer (1983) has defined the 


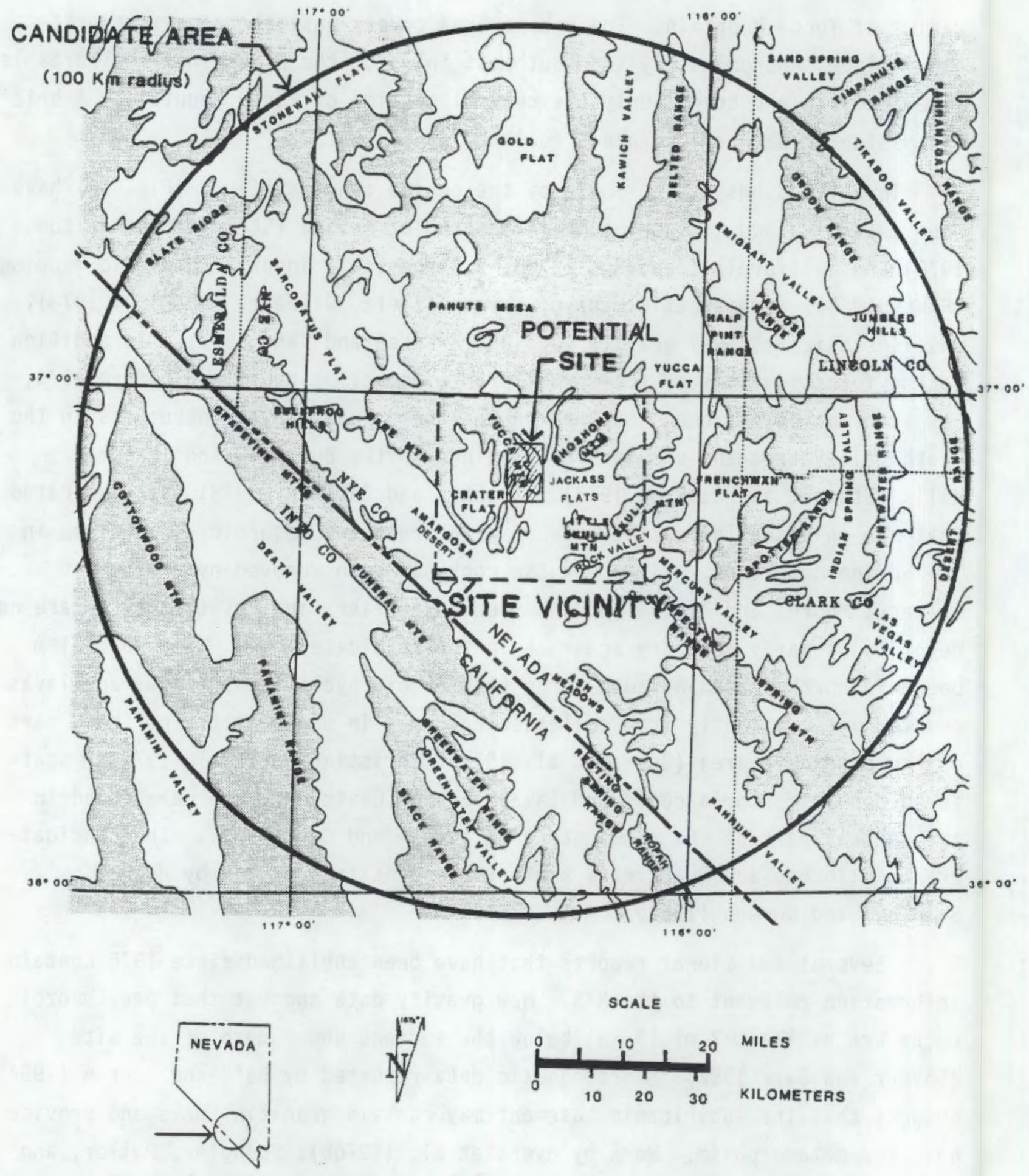

FIGURE 15. Location of Candidate Area and Potential Site (after USGS 1984) 
principal characteristics of rock types obtained from test well USW H-1. Detailed geologic fault studies have been conducted at Yucca Mountain by Scott et a1. (1982, 1984) and by Scott and Bonk (1984) (Fig. 16). Stress fields have been discussed by Zoback and Thompson (1978), Zoback and Zoback (1980), and Zoback, Anderson, and Thompson (1981). Seismicity has been investigated by Rogers, Perkins, and McKeown (1976); Rogers, Wuollet, and Covington (1977); Rogers, Harmsen, and Carr (1981, 1983); Ekren et al. (1977); and Vetter and Ryall (1983). 


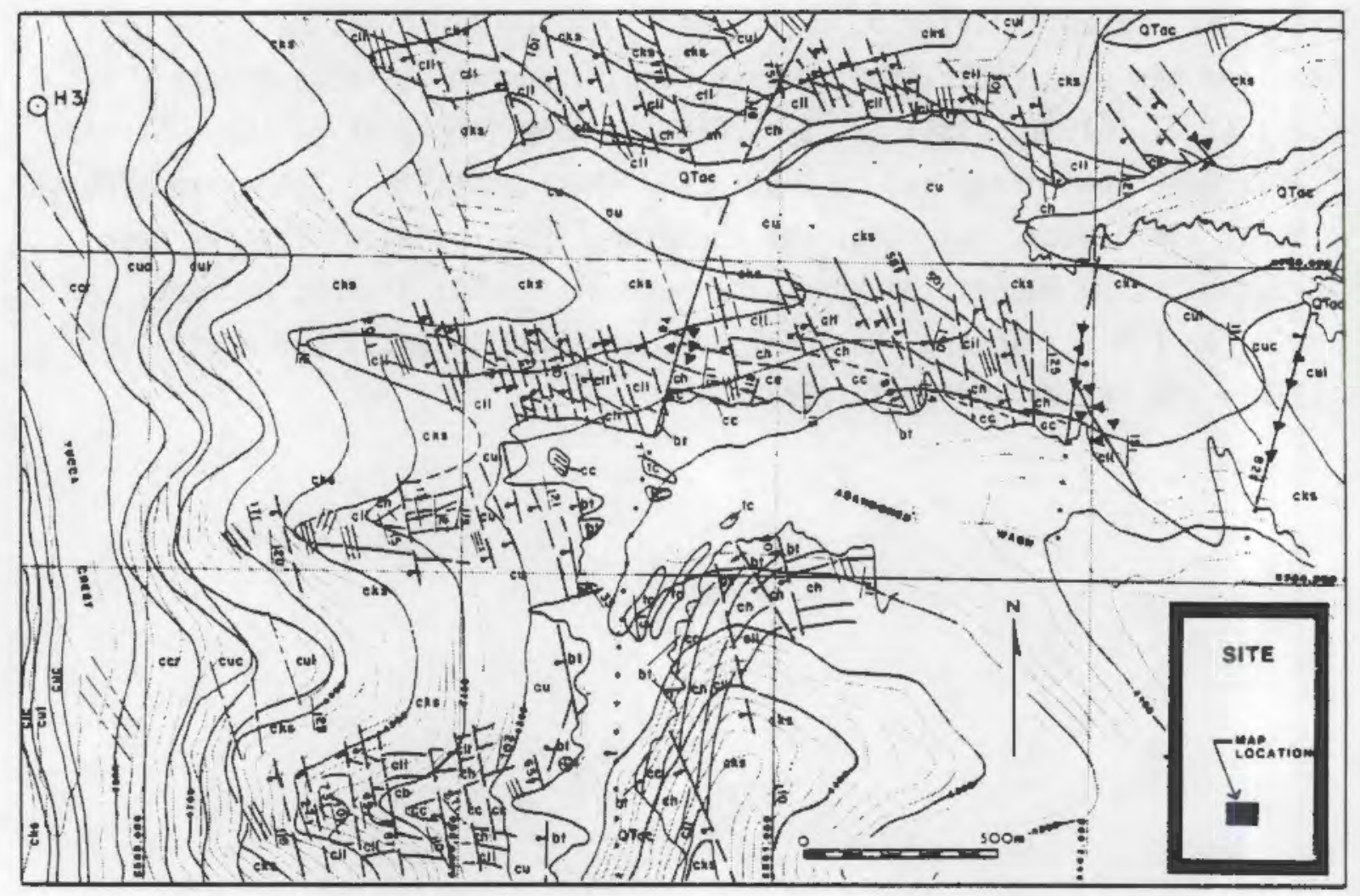

\section{EXPLANATION}

cc-columnar zone

bt-bedded tuffs

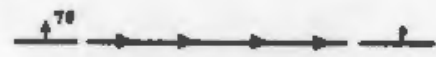

tc caprock zone

QTac-alluvium and colluvium

cu-Tiva Canyon Member of Paintbrush Tuff

faults showing dip, bar and ball on downthrown side, triangle shaped arrow shows trend and plunge of slickensides.

Ccr-caprock zone

Cuc-upper cliff zone

Cul-upper lithophysal zone

cks-clinkstone zone

cll-lower lithophysal

ch-hackly zone

FIGURE 16. Geologic Map of the Abandoned Wash Block at Yucca Mountain (from Scott et al. 1982) 


\section{SURFACE-WATER HYDROLOGY}

With the exception of Fortymile Wash and drainage areas near Pahute Mesa, there are no important perennial or intermittent streams at the NTS or in the surrounding area (Borg et a1. 1976). Watershed areas for the NTS and its vicinity are shown in Fig. 17.

Surface water as a source exists reliably only at springs in Oasis Valley, the Amargosa Desert, and Death Valley. Because of the extreme aridity of the region, where annual precipitation averages about $20 \%$ of the potential evapotranspiration, most of the spring discharge travels only a short distance before evaporating or infiltrating into the ground (DOE 1986).

Rapid runoff during heavy precipitation fills the normally dry washes for brief periods. Local flooding can occur where the water exceeds the capacity of the channels. In contrast to the washes, the playas in which many of the washes terminate may contain standing water for days to weeks after severe storms (DOE 1986). A considerable part of this water may evaporate and part may infiltrate and introduce moisture into the vadose zone; whether or not this becomes a source of recharge to the saturated zone has not been demonstrated, but the general opinion is that it does not (Borg et al. 1976).

Since 1976, flooding potential has been investigated at two places on the NTS. Squires and Young (1984) estimated the 100-year, 500-year, and regional maximum floods along a $9-\mathrm{mi}(14.5-\mathrm{km})$ section of Fortymile Wash and its three principal tributaries. Along the study section of Fortymile Wash and at Yucca Wash, all three estimated maximum floods would remain within the stream channels. For the Busted Butte and Drill Hole Wash drainages, the report indicated that the 500-year flood would exceed stream-channel capacities at several places and that the regional maximum flood would inundate sizable areas in the central parts of the watershed. Erosion and deposition would probably be significant during the 100-year flood, and they could be severe during the 500-year and regional maximum floods. 


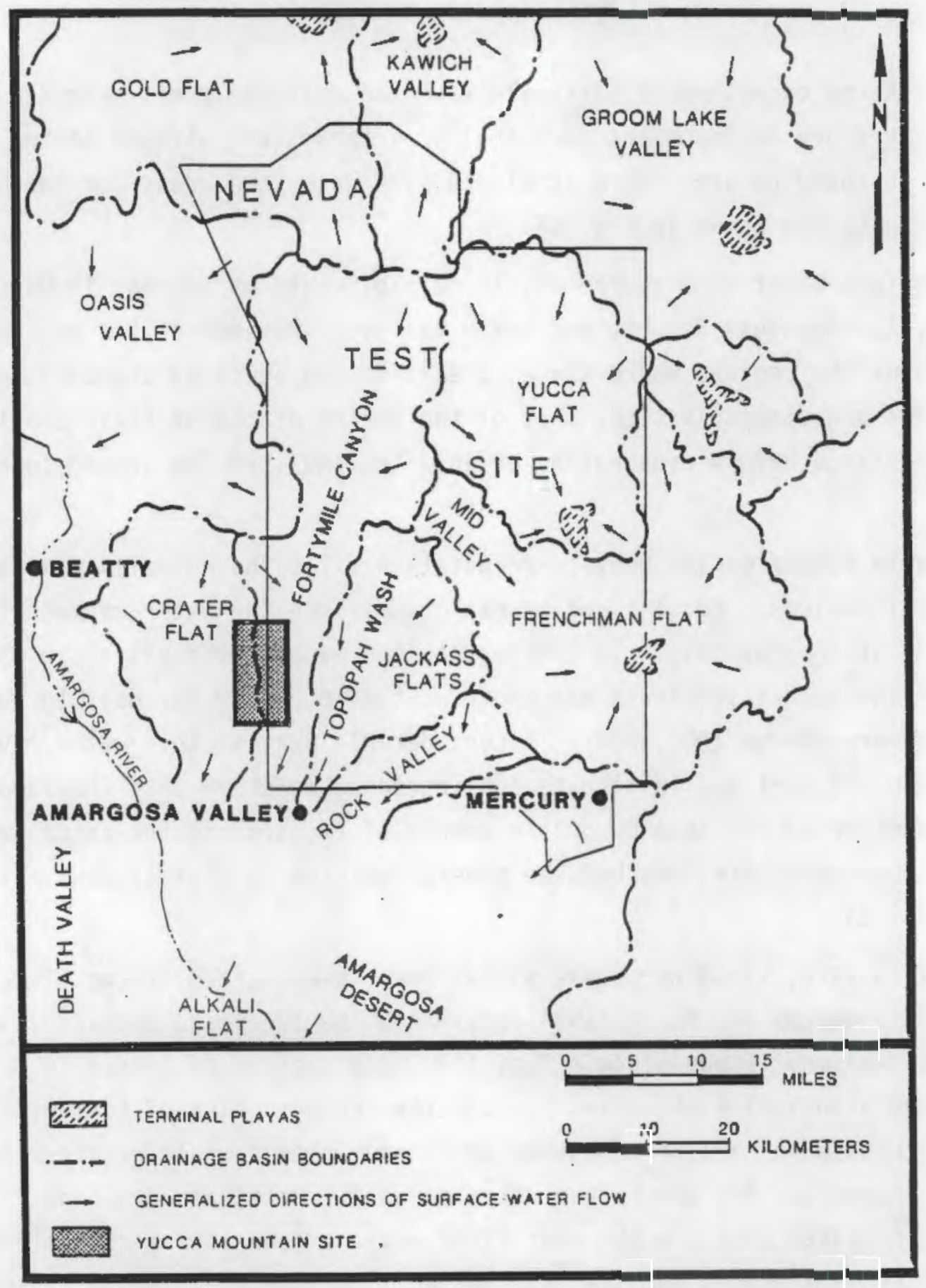

FIGURE 17. Drainage Basins in the Yucca Mountain Area Showing Direction of Flow of Surface Water (modified from ERDA 1977) 
Case et al. (1984) reported an investigation of the flood hazard con- . ducted as part of the site characterization for the Defense Low-Level Waste Management Site at the NTS. The Radioactive Waste Management Site (RWMS) is situated at the junction of major alluvial fans to the east and west, with several smaller fans merging from the north. Because flooding on alluvial fans has such distinctive characteristics, methods of hydraulic engineering cannot be used to assess the extent and seriousness of flooding (Case et al . 1984). Geometric data for the alluvial fans surrounding the RWMS were used to calculate conditional probabilities of a flood event in a specific return period reaching the RWMS. This study concluded that the probability is high that the RWMS site will be hit at least once during its design life (assumed to be 100 years) by a flood of significant size, and that the potential for the site to be hit several times during its design life is also high. The RWMS site, however, is situated at the junction of major alluvial fans, and the calculated flood hazard reflects the fact that the processes that formed the fans on which the site is located are likely to continue. Given that the Case et al. (1984) study dealt with the probability of flash flooding on alluvial fans in an arid environment, a situation for which data are scarce or lacking, its conclusions should not be extrapolated to a regional or areal interpretation. 


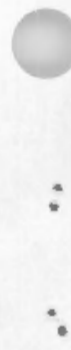

$\because$

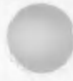

"

:

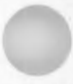




\section{MOISTURE TRANSPORT IN THE UNSATURATED ZONE}

Many nuclear devices have been detonated above the water table in the unsaturated (vadose) zone at the NTS (Borg et a1. 1976). However, Borg et al. concluded that potentially mobile radionuclides deposited by nuclear explosions in the vadose zone were, at least temporarily, isolated from the saturated ground-water flow system and that first priority in investigating subsurface radionuclide transport at the NTS should be given to studying transport from the sites of those tests carried out in the saturated zone.

Most of the tests conducted above the water table have occurred beneath Yucca Flat. Potential movement of any mobile radionuclides deposited by the detonations would depend on the processes of moisture transport operating in the explosion-modified environment of the vadose zone. If moisture is transported through the vadose zone from the land surface to the water table, any mobile radionuclides produced by the tests in the vadose zone could be transported downward. Depending on the speed and efficiency of the downward transport, some radionuclide contamination of the saturated ground-water system could result.

Borg et a1. (1976) reported that moisture transport in the unsaturated zones of Yucca and Frenchman Flats had not been described at that time, but that some information bearing on the question was available. Such information included climatological data, stratigraphic descriptions of material in the vadose zone, and general knowledge of the depth to the zone of saturation.

Some of the important relations influencing moisture movement in the vadose zone, the driving forces that affect movement, and a review of some experimental work in unsaturated flow have been discussed by Borg et a1. (1976). Pressure potential, matrix potential, gravitational potential, osmotic potential, suction, tension, hydraulic conductivity, and water content were considered. The differences between saturated and unsaturated materials with respect to moisture movement were pointed out, and it was stated that no fundamentally based equation of general validity was available to relate conductivity, water content, and pressure potential; nor did 
existing knowledge permit reliable prediction of unsaturated hydraulic conductivity from basic rock properties. Borg et al. (1976) also mentioned that, although isothermal conditions are often assumed for moisture movement in the vadose zone, movement over any finite distance does not really occur under isothermal conditions and a temperature gradient in the vadose zone will cause water to move toward a cooler area in both liquid and vapor phases.

Borg et al. (1976) reviewed some of the literature dealing with thermally driven water flux in the vadose zone and concluded that general agreement on the mechanisms responsible for flow was lacking and that the mathematical models developed up to that time, which were generally onedimensional and considered only the hydraulic gradient, were oversimplifications and of limited usefulness.

Several field studies described by Borg et al. (1976), including some that traced tritium from atmospheric testing, attempted to chart the pattern of moisture transport in the vadose zone. Results of these studies seem to indicate that moisture transport data are generally specific to the area studied and are affected by differing conditions relative to such factors as soil type and thickness, depth to the saturated zone, vegetation, evapotranspiration, antecedent soil moisture, rate and duration of precipitation events, time of year precipitation occurs, and temperature regime. It has been well documented that vapor transport and upward movement of soil moisture occur in the unsaturated zone.

Kearl (1982) instrumented an alluvial soil site in Area 5 to examine and quantitatively describe the physical processes controlling moisture movement in the upper $20 \mathrm{ft}(6.1 \mathrm{~m})$ of the desert soil of the NTS. The study included monitoring baseline conditions of soil moisture and temperature using thermocouple psychrometers and neutron moisture probes, simulating a major precipitation event with a sprinkler system and monitoring its effects, and making laboratory measurements of soil moisture characteristics beginning with hydrautic conductivity.

Baseline information revealed a zone of higher moisture content at approximately $5 \mathrm{ft}(1.5 \mathrm{~m})$ below the dry surface layer that was caused by 
evaporation, moisture transport to depth, and transpiration. Results of a simulated 500-year precipitation event indicated that water penetrated to a depth of $2.9 \mathrm{ft}(0.9 \mathrm{~m})$. Vapor transport was primarily responsible for water movement at this depth, because of the low moisture content. Temperature gradients are believed to be substantially responsible for vapor transport by preferentially sorting water vapor molecules from the surrounding air, using the soil as a molecular sieve. The depth to which solar radiation and precipitation directly affected the soil appeared to be about $17 \mathrm{ft}(5.2 \mathrm{~m})$ (Kearl 1982).

Two studies since the Borg et al. report (1976) have dealt with the unsaturated zone at Yucca Mountain in connection with work for the underground waste repository. Wang and Narasimhan (1985) developed a general statistical theory to describe flow along and across fractures that separate partially saturated matrix blocks. Model simulations indicated that transient change from fully to partially saturated conditions depends strongly on fracture properties, and that changes in fluid flow under nearly steady-state conditions in a partially saturated, fractured, porous system could be simulated approximately without taking the fractures into account.

Montazer and Wilson (1984) proposed a conceptual model for flow in the unsaturated zone at Yucca Mountain. They divided the unsaturated zone at Yucca Mountain into five informal hydrologic units and developed a hypothetical model for flow through porous layers intercalated with double-porosity layers. The proposed model included such features as fracture and matrix flow, retardation of flow by capillary barriers, infiltration into fractured material, lateral flow, perched water zones, and vapor movement. Montazer and Wilson (1984) also listed a number of items to be considered in further investigations of the unsaturated zone at Yucca Mountain. Even though the materials considered are not completely analogous to those in Frenchman and Yucca Flats, the approach and components used in the conceptual model could be useful, possibly for examining the collapse craters where explosioninduced fractures exist in the vadose zone.

Tyler (1987) reviewed soil moisture studies on the NTS; Tyler et al. (1986) discussed the impacts of subsidence craters on ground-water recharge. 
Russell et al. (1987) discussed the effects of unsaturated conditions at Rainier Mesa and concluded that the recharge at Rainier Mesa may transmit. radionuclides from tests to the saturated zone, especially if the recharge water bypasses the low-permeability zeolitic tuff directly below the level of tunnel testing. 


\section{HYDROGEOLOGY OF THE NEVADA TEST SITE AND VICINITY}

The hydrogeology of the NTS and its vicinity was detailed by Borg et al. (1976) in an expanded summary that reviewed what was known concerning the subject up to 1976. The work by Winograd, Thordarson, and Young (1971), superseded by USGS Professional Paper 712-C (Winograd and Thordarson 1975a), served as the principal basis for the summary. The following condensed summary of the NTS hydrogeology is abstracted from these sources and work by Hansen (1978). Additional information published on NTS hydrogeology from 1976 to 1988 is then discussed.

The general hydrogeology of the NTS has been studied since at least the early 1960s, and the hydrologic systems are fairly well defined (Eakin, Schoff, and Cohen 1963; Winograd, Thordarson, and Young 1971; Blankennage1 and Weir 1973; Winograd and Thordarson 1975a). Site hydrogeology is complex, as a result of two major periods of crustal deformation that occurred in the area. It appears that two ground-water systems are present at the NTS. The western part of the NTS is within the Ash Meadows Ground-Water Basin; the eastern part of the NTS is within the Pahute Mesa Ground-Water System. Fig. 18 (Borg et al. 1976) shows the approximate location of the boundary between the two systems. The two systems have been studied by different investigators (Winograd and Thordarsen 1975a; Blankennagel and Weir 1973), and it seems that there is not a direct correlation of the hydrogeologic units between the two systems. Ground-water investigations on the NTS and in other places in southern and eastern Nevada indicate that each topographic basin drainage area does not usually have a discrete ground-water system, but that there is usually considerable interbasin flow of ground water (Borg et a). 1976). The hydrogeologic units at the NTS were developed on the basis of stratigraphic units (or combinations thereof) that have similar hydrologic characteristics, rather than by the more conventional practice of designating discrete formations as aquifers or aquitards (Winograd and Thordarson 1975a). 


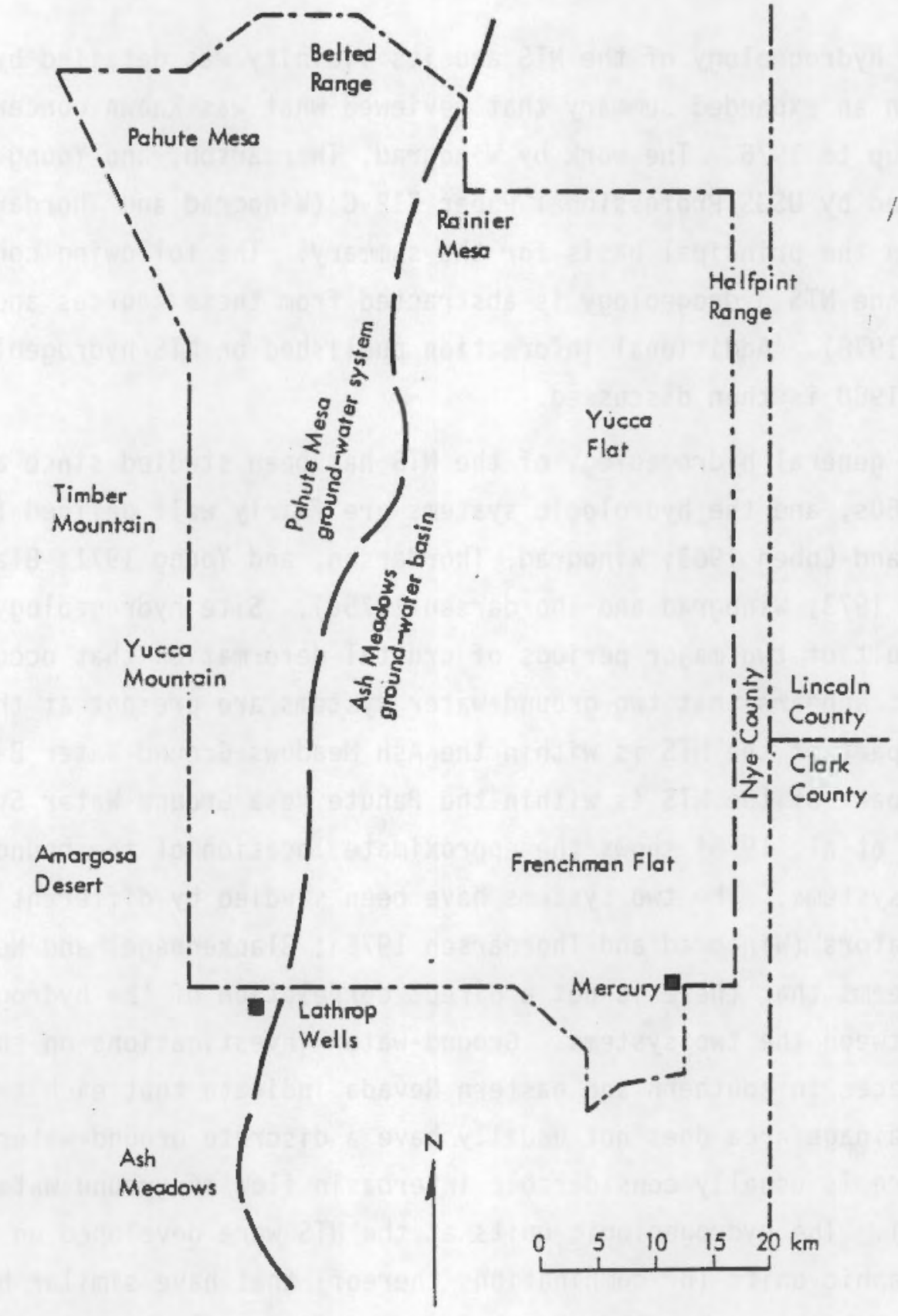

FIGURE 18. Approximate Location of Boundary Between Ash Meadows Ground-Water Basin and Pahute Mesa Ground-Water System, NTS (after Borg et al. 1976) 


\section{ASH MEADOWS GROUND-WATER BASIN}

Table 2 (condensed from Winograd and Thordarson 1975a) shows the hydrogeologic units for the Ash Meadows ground-water basin at the NTS and indi-

cates some of the unit characteristics. In order of increasing geologic age (and generally increasing depth beneath ground surface at the NTS), the hydrogeologic units within the Ash Meadows Ground-Water Basin are

1) VALLEY FILL AQUIFER - This unit consists of tuffaceous silts, sands, and gravels of Quaternary and Tertiary ages. The sediments are generally unconsolidated, but they may be cemented by caliche in places. The Valley Fill Aquifer is used for water supply in the Frenchman Flat area, but elsewhere, in Yucca Flat, western Jackass Flats, and Mercury Valley, it is mostly above the zone of saturation because the water table is so deep in these areas. The Valley Fill Aquifer is more than $3,353 \mathrm{ft}(1,100 \mathrm{~m})$ thick in the southern part of Yucca Flat, 1,570 ft $(515 \mathrm{~m})$ thick in the central part of Frenchman Flat, and $963 \mathrm{ft}(316 \mathrm{~m})$ thick in Jackass Flats. Evaluation of pumping tests of three wells completed in the valley Fi11 Aquifer indicates that transmissivity of this unit ranges from 278 to $1,524 \mathrm{ft}^{2}$ (30 to $164 \mathrm{~m}^{2}$ ) per day (Winograd and Thordarson 1975a).

2) LAVA FLOW AQUIFER - The Lava Flow Aquifer underlies the Valley Fill Aquifer in a limited area within the NTS. The geologic formations that make up the Lava Flow Aquifer (Skull Mountain Basalt, Shoshone Mountain Rhyolite, and Kiwi Mesa Basalt) are as much as 2,134 ft $(700 \mathrm{~m})$ thick, but they are present only in Jackass Flats, and they are probably within the zone of saturation only in the east-central part of the Flats. No information on hydraulic characteristics of the Lava Flow Aquifer was found in the published data reviewed.

3) WELDED TUFF AQUIFER - This unit is 1 imited to the structurally deepest parts of Yucca Flat, Frenchman Flat, and Jackass Flats, although the stratigraphic members that compose the aquifer are 
TABLE 2. Geohydrologic Units at the NTS (Exclusive of Pahute Mesa Area) (condensed from Winograd and Thordarson 1975a)

\begin{tabular}{|c|c|c|c|}
\hline $\begin{array}{l}\text { Hydrogeologic } \\
\text { Unit }\end{array}$ & $\begin{array}{c}\text { Stratigraphic } \\
\text { Unit }\end{array}$ & Lithology & Transmissivit \\
\hline $\begin{array}{l}\text { Valley-Fill } \\
\text { Aquifer }\end{array}$ & $\begin{array}{l}\text { Holocene to Pliocene } \\
\text { Valley fill }\end{array}$ & $\begin{array}{l}\text { Alluvial fan, fluvial } \\
\text { fanglomerate, lacus- } \\
\text { trine, and mudflow } \\
\text { deposits }\end{array}$ & $\begin{array}{l}324 \text { to } 1,771 \\
\mathrm{ft}^{2} / \mathrm{d}(30 \\
\left.\text { to } 164 \mathrm{~m}^{2} / \mathrm{d}\right)\end{array}$ \\
\hline Lava-Flow Aquifer & $\begin{array}{l}\text { P1iocene Kiwi Mesa, } \\
\text { Shoshone Mt. \& } \\
\text { Skull Mt. Forma- } \\
\text { tions }\end{array}$ & $\begin{array}{l}\text { Basalt \& rhyolite } \\
\text { Flows }\end{array}$ & Not defined \\
\hline $\begin{array}{l}\text { Welded-Tuff } \\
\text { Aquifer }\end{array}$ & $\begin{array}{l}\text { Pliocene Timber Mt. } \\
\text { Tuff \& Miocene } \\
\text { Paintbrush Tuff }\end{array}$ & $\begin{array}{l}\text { Unwelded to welded } \\
\text { ash-flow tuff }\end{array}$ & Not defined \\
\hline $\begin{array}{l}\text { Bedded-Tuff } \\
\text { Aquifer }\end{array}$ & Miocene Bedded Tuff & Ash-fall tuff & $\begin{array}{l}173 \mathrm{ft}^{2} / \mathrm{d} \\
\left(16 \mathrm{~m}^{2} / \mathrm{d}\right) \\
\text { (one wel1) }\end{array}$ \\
\hline $\begin{array}{l}\text { Lava-Flow } \\
\text { Aquiclude }\end{array}$ & $\begin{array}{l}\text { Miocene Wahmonie } \\
\text { Formation }\end{array}$ & $\begin{array}{l}\text { Lava-flow \& inter- } \\
\text { flow \& breccia }\end{array}$ & Not defined \\
\hline Tuff Aquitard & $\begin{array}{l}\text { Miocene Salyer, } \\
\text { Indian Trail, } \\
\text { Calico Hills For- } \\
\text { mations; Miocene/ } \\
\text { 0ligocene Crater } \\
\text { Flat Tuff, Pavits } \\
\text { Springs Formation; } \\
\text { 01igocene Horse } \\
\text { Spring Formation }\end{array}$ & $\begin{array}{l}\text { Ash-fall \& ash-flow } \\
\text { tuff, rhyolite, } \\
\text { interflow sediments }\end{array}$ & Low \\
\hline $\begin{array}{l}\text { Upper Carbonate } \\
\text { Aquifer }\end{array}$ & $\begin{array}{l}\text { Permo-Pennsylvanian } \\
\text { Tippipah Formation }\end{array}$ & Limestone & Not defined \\
\hline $\begin{array}{l}\text { Upper Clastic } \\
\text { Aquitard }\end{array}$ & $\begin{array}{l}\text { Mississippian/ } \\
\text { Devonian Eleana } \\
\text { Formation }\end{array}$ & $\begin{array}{l}\text { Argillite, quartzite, } \\
\text { conglomerate }\end{array}$ & $\begin{array}{l}<80 \mathrm{ft}^{2} / \mathrm{d} \\
\left(<7.4 \mathrm{~m}^{2} / \mathrm{d}\right)\end{array}$ \\
\hline $\begin{array}{l}\text { Lower Carbonate } \\
\text { Aquifer }\end{array}$ & $\begin{array}{l}\text { Section from the } \\
\text { Devonian Devils } \\
\text { Gate Formation to } \\
\text { the Cambrian } \\
\text { Carrara Formation }\end{array}$ & Limestone, dolomite & $\begin{array}{l}173 \text { to } 5,238 \\
\mathrm{ft} t^{2} / \mathrm{d}(16 \\
\left.\text { to } 485 \mathrm{~m}^{2} / \mathrm{d}\right)\end{array}$ \\
\hline
\end{tabular}


TABLE 2. (contd)

\begin{tabular}{|c|c|c|c|}
\hline $\begin{array}{c}\text { Hydrogeologic } \\
\text { Unit }\end{array}$ & $\begin{array}{c}\text { Stratigraphic } \\
\text { Unit }\end{array}$ & Lithology & Transmissivity \\
\hline $\begin{array}{l}\text { Lower Clastic } \\
\text { Aquitard }\end{array}$ & $\begin{array}{l}\text { Cambrian Carrara (in } \\
\text { part), Zasbriskie } \\
\text { Formation, Wood } \\
\text { Canyon Formation; } \\
\text { Precambrian Stir- } \\
\text { ling \& Johnnie } \\
\text { Formations }\end{array}$ & $\begin{array}{l}\text { Quartzite, siltstone, } \\
\text { shale }\end{array}$ & $\begin{array}{l}<81 \mathrm{ft}^{2} / \mathrm{d} \\
\left(<7.5 \mathrm{~m}^{2} / \mathrm{d}\right)\end{array}$ \\
\hline
\end{tabular}

present (above the zone of saturation) over much of the NTS.

Aquifer transmissivity, as estimated from very 1 imited well tests, ranges from about 23 to $7,850 \mathrm{ft}^{2}\left(2.5\right.$ to $\left.845 \mathrm{~m}^{2}\right)$ per day.

4) BEDDED TUFF AQUIFER - This unit is also limited to the structurally deepest parts of Yucca Flat, Frenchman Flat, and Jackass Flats. Evaluation of one well-pumping test indicated an aquifer transmissivity of $149 \mathrm{ft}^{2}\left(16 \mathrm{~m}^{2}\right)$ per day for this unit.

5) LAVA FLOW AQUITARD - This unit occurs primarily in the northwest part of Frenchman Flat. Little is known about the characteristics of the Lava Flow Aquitard, because few boreholes have intercepted the unit.

6) TUFF AQUITARD - This unit occurs in Yucca Flat, western Jackass Flats, and Frenchman Flat as a thick $(1,829$ to $4,267 \mathrm{ft}$ or 600 to $1,400 \mathrm{~m}$ ) series of nonwelded to welded ash-fall and ash-flow tuffs and intercalated volcanic and sedimentary rocks. The Tuff Aquitard separates the Welded and Bedded Tuff Aquifers from the underlying Upper Carbonate Aquifer. The low interstitial permeability and the lack of connected fractures in this unit limit the interconnection of the overlying and underlying aquifers.

7) UPPER CARBONATE AQUIFER - The occurrence of this unit at the NTS is limited to the western part of Yucca Flat. El sewhere on the NTS, the associated stratigraphic unit (Tippipah Limestone) either has been eroded or occurs above the zone of saturation. Aquifer 
characteristics have not been measured quantitatively on the NTS, but the unit is expected to be similar in character to the Lower Carbonate Aquifer.

8) UPPER CLASTIC AQUITARD - This unit occurs totally in the Mississippian and Devonian Eleana Formation, which consists of up to $7,315 \mathrm{ft}(2,400 \mathrm{~m})$ of argillite, quartzite, and conglomerate. The Upper Clastic Aquitard is important in separating the Upper Carbonate Aquifer from the Lower Carbonate Aquifer in western Yucca Flat. The unit also occurs in the northern part of Jackass Flats. El sewhere at the NTS, the Eleana Formation either has been eroded away or occurs above the zone of saturation.

9) LOWER CARBONATE AQUIFER - This unit occurs in a thick series of Devonian, Silurian, Ordovician, and Cambrian limestones and dolomites (with minor amounts of other sedimentary rocks). The Lower Carbonate Aquifer has wide areal distribution at the NTS, and, along with the Valley Fill Aquifer, it is an important water supply source in the region. The Lower Carbonate Aquifer typically is several hundred meters thick, and aquifer transmissivity ranges from 149 to $4,505 \mathrm{ft}^{2}$ (16 to $485 \mathrm{~m}^{2}$ ) per day, based on results from limited well-pumping tests (Winograd and Thordarson 1975a). Fracture porosity (rather than interstitial porosity) controls groundwater occurrence and flow in the Lower Carbonate Aquifer.

10) LOWER CLASTIC AQUITARD - This unit has wide distribution throughout the NTS, and it provides an effective lower boundary for the Lower Carbonate Aquifer. The Aquitard is made up of Cambrian and Precambrian siltstones, quartzites, shales, and sandstones. The unit has low fracture and interstitial hydraulic conductivity (Winograd and Thordarson 1975a).

\section{PAHUTE MESA GROUND-WATER SYSTEM}

The eastern part of Pahute Mesa is the only part of this area that has been studied in any detail (Blankennagel and Weir 1973). Miocene-age fractured rhyolitic lava flows and welded tuffs make up the aquifers in this 


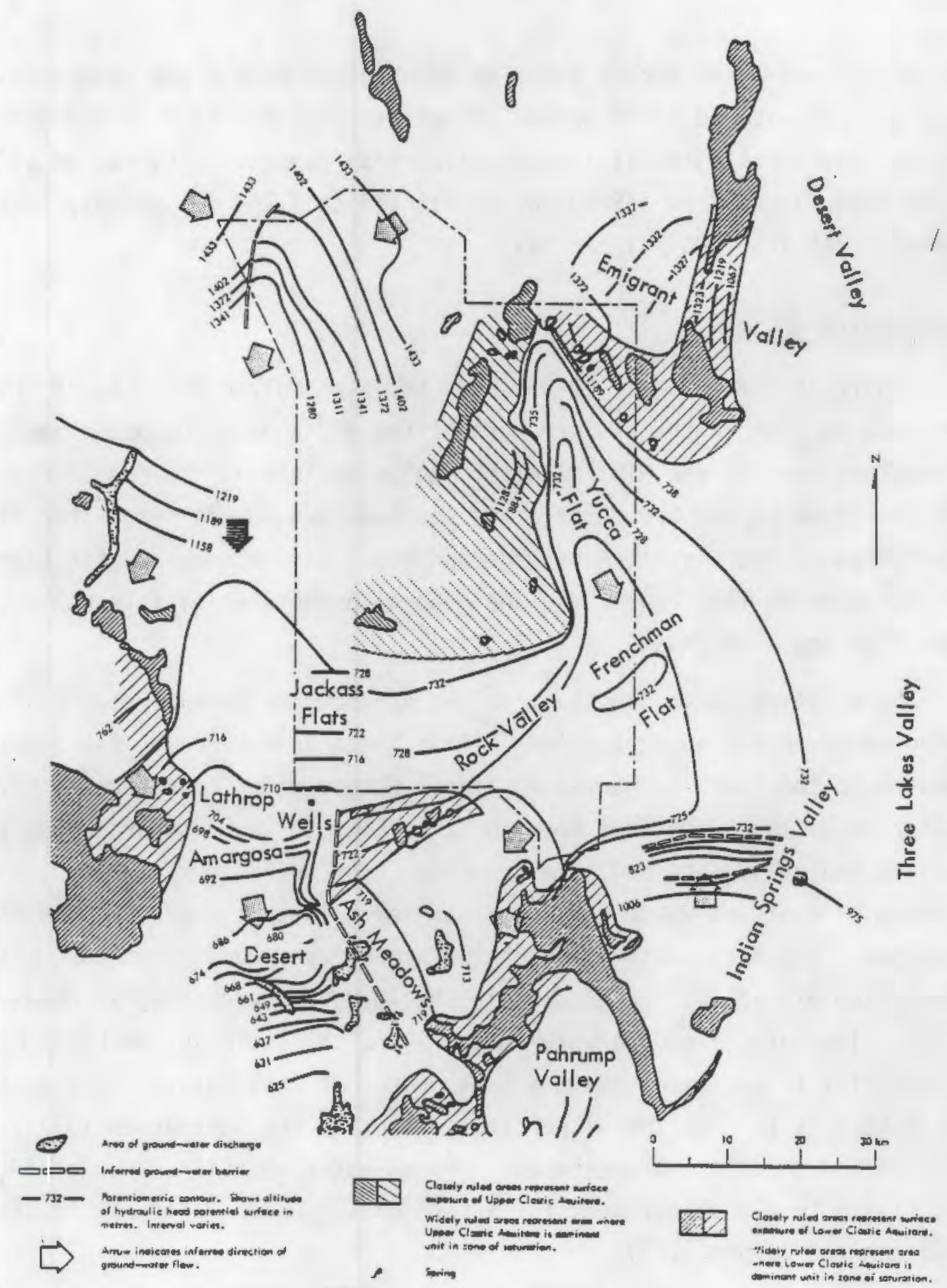

FIGURE 19. Hydrogeologic Map of the NTS and Vicinity (after Winograd and Thordarson 1975a) 
system. Ground water occurs and flow takes place within the fractures. Nonwelded and altered tuffs appear to act as aquitards in this hydrogeologic system. Aquifer transmissivities derived from pumping tests run on 14 wells in the Mesa ranged from 158 to $16,165 \mathrm{ft}^{2}$ (17 to $1,740 \mathrm{~m}^{2}$ ) per day, with a mean of $3,716 \mathrm{ft}^{2}\left(400 \mathrm{~m}^{2}\right)$ per day.

\section{GROUND-WATER MOVEMENT}

Figure 19 (Borg et a1. 1976) shows the piezometric surfaces of the Lower Carbonate Aquifer in the eastern part of the NTS and the Cenozoic aquifers in the western part of the NTS. Aquifer equipotentials in the Cenozoic strata are also shown beyond the western and southwestern boundaries of the NTS. Occurrences of the Clastic Aquitards and hypothesized ground-water barriers are indicated on the figure, and the general directions of inferred groundwater flow are also shown.

The existing data show that, in the Ash Meadows Ground-Water Basin, ground water in the upper aquifers within Yucca and Frenchman Flats moves downward to the Lower Carbonate Aquifer. Ground water in the Lower Carbonate Aquifer moves southward from beneath Yucca Flat to the discharge area at Ash Meadows, and perhaps beyond, via Frenchman Flat and Mercury Valley. There is evidence of a ground-water divide or barrier between the NTS and the city of Las Vegas. The first natural discharge areas for ground water that passes beneath the NTS are at Ash Meadows in the Amargosa Desert and at 0asis Valley. The rate of ground-water movement to the south in the Lower Carbonate Aquifer is estimated (with a high degree of uncertainty) to range from 5.5 to $54.9 \mathrm{ft}(1.8$ to $180 \mathrm{~m}$ ) per year (Winograd and Thordarson 1975a). A more refined calculation indicated a ground-water velocity range of 54.9 to $1250 \mathrm{ft}(18$ to $410 \mathrm{~m})$ per year for a part of the Lower Carbonate Aquifer (Claassen and Cordes 1975).

Ground water in the eastern part of Pahute Mesa is inferred to move toward the south-southwest and southward through Oasis Valley, Crater Flat, and western Jackass Flats toward the Amargosa Desert. Ground water from the Pahute Mesa system apparently discharges in the Oasis Valley and Amargosa Desert, west of the Ash Meadows springs. Rates of ground-water flow have 
been estimated to range from 6.1 to $232 \mathrm{ft}$ (2 to $76 \mathrm{~m}$ ) per year beneath eastern Pahute Mesa (B1ankennagel and Weir 1973).

\section{INVESTIGATIONS OF SITE HYOROLOGY SINCE 1976}

Numerous hydrogeologic investigations have been made since publication of the document by Borg et al. (1976), when essentially all existing information on NTS hydrogeology up to 1976 was compiled, summarized, and evaluated. Since that date, there seems to have been little refinement of the general hydrogeology on the NTS. Most of the investigations reported and documented since 1976 deal with specific site characteristics or discrete geohydrologic phenomena.

Geohydrologic data and test results from well $\mathrm{J}-13$ were reported by Thordarson (1983). The report is an analysis of the original data from well J-13, drilled in 1962, and additional data collected through 1983. The well was originally intended to be used to examine characteristics of the Paleozoic carbonate rocks at this site, but the well bottomed in Tertiary tuff. The only data presented by Thordarson (1983) were hydrogeologic, geophysical, and hydrochemical information previously collected from well J-13. Although the document also presented the results of the 1983 analyses, no comparison was made with other data.

The paleohydrology of the southern Great Basin has been described, with special reference made to water-tabie fluctuations beneath the NTS during the late (?) Pleistocene (Winograd and Doty 1980). In that study, a reconnaissance of modern and fossit spring deposits was made. Applying hydrologic considerations to the spring deposits, it was suggested that a possible rise of 18 to $274 \mathrm{ft}(6$ to $90 \mathrm{~m})$ in the potentiometric level beneath central Frenchman flat could have occurred in Pleistocene time. However, this rise probably did not exceed $91 \mathrm{ft}(30 \mathrm{~m})$ during Wisconsin time. Therefore, it can be concluded that water-level increases beneath Frenchman Flat during potential future pluvial periods are unlikely to exceed $91 \mathrm{ft}(30 \mathrm{~m})$, and in fact the water levels then may be lower than the current levels.

A major carbon-14 anomaly in a regional carbonate aquifer was discussed and documented by Winograd and Pearson (1976), who indicated possibie 
evidence of large-scale channeling in the south-central Great Basin. A major trough in the potentiometric surface in the regional carbonate aquifer was hypothesized as extending from eastern Frenchman Flat to Ash Meadows. The existence of this trough is supported by the presence of a major carbon-14 anomaly, suggestive of major flow channeling, at the center of a 10-mi(16-km-)long fault-controlled spring line at Ash Meadows. The conclusion drawn was that the dense fractured $\mathrm{Paleozoic}$ carbonate rock making up the Nevada aquifer may not be as homogeneous in its heterogeneity as has generally been assumed for modeling.

A 1980 water-table map of the Yucca Flat area was published by Doty and Thordarson (1983). This is an informative map; however, it lacks text descriptions, and there are no references to past work in defining aquifer potentiometric surfaces.

A geochemical interpretation of sources and mechanisms for recharge of ground water in the west-central Amargosa Desert has been discussed and reported by $\mathrm{Cl}$ aassen $(1983,1985)$. These reports indicate that ground water was recharged to the valley fill Aquifer primarily by overiand flow in or near present-day stream channels. The overflow water was probably derived from snowmelt. Isotope data indicate that the major recharge occurred near the end of the Pleistocene and through the early Holocene. No ground water has so far been dated as older than 17,000 years. Therefore, it was assumed that only minor recharge occurred before that time, and that ground-water velocities are lower than $21 \mathrm{ft}(7 \mathrm{~m})$ per year and probably lower than $12 \mathrm{ft}$ $(4 \mathrm{~m})$ per year.

A two-well recirculating tracer test was run in the Lower Carbonate Aquifer at the NTS (Claassen and Cordes 1975). The test yielded values of $2.9 \mathrm{ft}(1 \mathrm{~m})$ for the product of porosity and thickness and $50 \mathrm{ft}(16 \mathrm{~m})$ for aquifer dispersivity. The velocity of ground-water flow in the aquifer was estimated to range from 0.47 to $11 \mathrm{ft}(0.1$ to $3.5 \mathrm{~m})$ per day. A method for analys is of non-dispersed flow to observation wells in the flow net was also reported in this document.

Interaquifer leakage through uncased boreholes in Yucca Valley was reported by fenske (1978). The leakage rate through one uncased borehole 
from upper aquifers into the Lower Carbonate Aquifer was estimated to be on the same order as the total natural leakage through the Tuff Aquitard. If an uncased, unplugged borehole is near the site of an expended nuclear test that was conducted in the Alluvial Aquifer or the Tuff Aquitard, the effect of enhanced borehole ieakage will be to increase the transport of tritium in the Carbonate Aquifer. A method of calculating ground-water leakage was reported that uses straight-line solutions to the radial flow equations.

Water-table maps, a water-table gradient map, and depth-to-water maps were constructed for the NTS and the Central Nevada Test Area (Fenske and Carnahan 1975). The maps were constructed using a digital empirical mapping technique. Although this technique was developed for and applied to the specific areas mapped, it is directly applicable to any hydrologic province where ground-water recharge areas occur between the discharge sites.

Other reports were published on the application of transient barometric pressure tests for determining permeability of geologic formations and permeabifity of "chimneys" developed during nuclear tests (Hanson 1984, 1985).

Information on the geohydrology of the Climax Stock Granite and surrounding rock formations at the NTS was reported by Murray (1981). The location of the water table and the degree of saturation of the granitic rocks in the $\mathrm{Cl}$ imax Stock are currently unknown. Based on existing knowledge and extrapolation from available geohydrologic data, it appears the water tab7e may lie at about 3,353 to $3,658 \mathrm{ft}(1,100$ to $1,200 \mathrm{~m})$ above mean sea level in the northeastern part of the Climax Stock and at about 2,438 to $2,743 \mathrm{ft}(800$ to $900 \mathrm{~m})$ in the southwestern part of the Climax Stock. A drilling program would be required to establish these levels precisely. The degree of saturation at a given subsurface elevation may be approximated from a detailed inventory of seeps at that level. A more precise determination of saturation wilT require development of a water budget.

Structural control of ground-water movement in miogeosynclinal rocks of south-central Nevada was discussed and documented by Winograd and Thordarson (1975b). In south-central Nevada, major wrench, thrust, and normal faults and folds exert marked control on ground-water movement. Deformation of the 
carbonate rocks results in regions of high transmissibility, but juxtaposition of thick clastic strata against carbonate aquifers by fautting or folding results in prominent ground-water barriers, some of which are more than 10 miles $(16 \mathrm{~km})$ long. The apparent hydraulic gradients across the thick clastic aquitards vary from 150 to $1,300 \mathrm{ft} / \mathrm{mi}(28.4$ to $246 \mathrm{~m} / \mathrm{km})$. By contrast, gradients in the adjacent carbonate aquifers vary from 0.5 to $10 \mathrm{ft} /$ mile $(0.09$ to $1.89 \mathrm{~m} / \mathrm{km})$. Barriers may also result from gouges that have developed along the major fault zones. In upland areas, the clastic aquitards may exert control on the distribution of recharge. Where they are present in central parts of the flow system, the aquitards act as prominent ground-water dams and localize minor spring discharge. In discharge areas, they localize major spring 1 ines.

A number of investigations have dealt specificaliy with the Yucca Mountain site that has been proposed for geologic storage of defense-related high-level nuclear waste. Some of these investigations have some transfer value to the NTS as a whole, but others are useful only for evaluation of the specific site at Yucca Mountain. Many documents have reported the results of well tests made in support of site investigation and characterization of the Yucca Mountain site (Barr 1985; Bentley 1984; Bentley et a1. 1983; Craig, Reed, and Spengler 1983; Craig and Johnson 1984; Lahoud, Lobmeyer, and Whitfield 1984; Lobmeyer et a1. 1983; Rush, Thordarson, and Bruckheimer 1983; Thordarson, Rush, and Waddell 1985; Weeks and Wilson 1984; Whitfield, Thordarson, and Eshom 1984). These reports generally contain data on drilling operations and information on lithology, borehole geophysics, hydrologic monitoring, and testing (swabbing, injection tests, etc.) for test wells drilled for characterization of the Yucca Mountain site. Although specific to that site, the data give insight to probable hydrogeologic characteristics of similar geologic media elsewhere on the NTS.

A number of more comprehensive reports were published on the hydrogeology of the Yucca Mountain site. For instance, data were published on the hydrology of Yucca Mountain and its vicinity as part of site characterization (Wadde11, Robison, and Blankennagel 1984). This document contained data current through mid-1983 on surface-water hydrology, flood potential, regional ground-water hydrology, potentiometric levels, recharge and 
discharge areas, and isotopic and regional hydrochemistry. It also contained a preliminary description of the Yucca Mountain hydrogeologic system. Although this document addressed the Yucca Mountain site directly, the information also seems to be pertinent to the remainder of the NTS.

The chemical composition of ground water and locations of permeable zones were reported for the Yucca Mountain area by Benson et al. (1983). Ten wells in the Yucca Mountain area were sampled for chemical analysis. Sodium was shown to be the most abundant cation and bicarbonate the most abundant anion in all of the water samples. Although the general chemical compositions of individual samples were similar, there were significant differences in uncorrected ${ }^{14} \mathrm{C}$ age and in inorganic and stable-isotope compositions. Flow surveys of seven wells performed using $131_{\text {I }}$ as a tracer indicated that ground-water production is usualiy from one or more discrete zones of permeability.

\section{MODELING AND SIMULATION STUDIES SINCE 1976}

Since 1976, considerable effort has been made to develop numerical models for simulation. of various parts of the NTS hydrologic systems. Development of these models is probabiy the most significant work that has been done since that time to refine knowledge of site hydrogeology. The models may be of value in setting local hydrologic boundary conditions and can aid in defining the far-field ground-water flow system.

A quasi-three-dimensional ground-water model was developed for a portion of the NTS (Oberlander 1979). Ground-water systems have often been numerically modeled in two dimensions (height and length) by application of a finite-difference method. Such models do not account for water movement in the lateral extent perpendicular to the model. An empirical correction matrix was devised that partially adjusts a two-dimensional model for flow in the third dimension. The correction matrix was applied to the ground-water system from Pahute Mesa to Yucca Flat on the NTS. The geology of the area is complex and contains folded and thrust-faulted Paleozoic through Tertiary rocks. The modeling suggested that ground water is recharged at Pahute Mesa and flows to Yucca Flat at a rate of 64.8 acre-feet/year $\left(2.8 \times 10^{6} \mathrm{ft}^{3} / \mathrm{yr}\right.$; 
$\left.8.4 \times 10^{4} \mathrm{~m}^{3} / \mathrm{yr}\right)$. The maximum water flow under all of Yucca Flat and into the Ash Meadows ground-water system was estimated to be about 124 acre$\mathrm{ft} /$ year $\left(5.4 \times 10^{6} \mathrm{ft}^{3} / \mathrm{yr} ; 1.6 \times 10^{5} \mathrm{~m}^{3} / \mathrm{yr}\right)$.

A two-dimensional, steady-state numerical ground-water flow model has been developed for the NTS and vicinity by Waddel1 (1982). This model consists of a regional, two-dimensional, steady-state, horizontal-flow, finiteelement model of the ground-water flow system. The model was developed through the use of parameter estimation techniques. The purpose was to estimate ground-water fluxes and to study the effects of uncertainty in model parameters on these estimates. Sensitivities of fluxes derived from simulated heads and the head sensitivities were used to determine the parameters that would most affect predictions of radionuclide transport from a hypothetical repository in the southwest quadrant of the NTS. The model was meant to be regional in scope and not to be used for estimation of rates of transport, but rather for determining boundary conditions for more detailed transport modeling.

A finite-element ground-water flow model was developed by Czarnecki and Waddell (1984) to simulate ground-water flow in the vicinity of Yucca Mountain. The model is subregional and steady-state. The moder was developed through parameter estimation techniques for Yucca Mountain and its environs, assuming only horizontal flow. The primary objective of the model was to be of use in understanding the ground-water flow system beneath the Yucca Mountain area and for simulating the change in position of the water table caused by future climatic changes. Model results provide a preliminary basis for estimating the direction and time of ground-water travel. The documentation of the model also includes analyses of the sensitivity of estimated transmissivity parameters to variations in flux boundary conditions. This model should be useful for setting boundary conditions in the western part of the NTS in applications of other models to the NTS.

Increased recharge of the ground-water flow system of the Yucca Mountain site and its vicinity has been simulated by Czarnecki (1985). The study simulated the ground-water system using the model described by Czarnecki and Waddeil (1984). Although this investigation was specific to the Yucca 
Mountain area, many of the assumptions aiso apply to other areas of the NTS. Simulation of a $100 \%$ increase in precipitation over the present annual amount indicated that the maximum hydraulic head would rise $396 \mathrm{ft}$ (130 $\mathrm{m}$ ) [compared to the $610-\mathrm{ft}(200-\mathrm{m})$ rise that would be required to flood the proposed repository] and that water trave] times near the primary repository area at Yucca Mountain would decrease. The model assumes an empirical relationship between increased precipitation and consequent recharge, with little basis for this assumption. Of the increased recharge rates examined, an increase in flux into Fortymile wash had the greatest effect on the altitude of the water table in the primary repository area. Although the assumptions in this document apply primarily to Fortymile Wash, the assumptions can be applied elsewhere at and around the NTS to determine whether shot holes would be flooded.

Hydrologic mechanisms governing fluid flow in partially saturated, fractured, porous tuff at Yucca Mountain were described and reported by Wang and Narasimhan (1985). A general statistical theory was developed to describe flow along and across fractures that separate partially saturated matrix blocks. Model simulations indicate that transient change from fully to partialiy saturated conditions depends strongly on the fracture properties, and that changes in flujd flow under nearly steady-state conditions in a partially saturated, fractured, porous system could be simulated approximately without taking the fractures into account. Although this was applied expressiy to the Yucca Mountain site, the statistical theory can be applied to other areas of the NTS where tuff exists.

An additional preliminary two-dimensional regional hydrologic model of the NTS and its vicinity was developed and documented by Rice (1984). This regional model is two-dimensional, finite-difference, and steady-state, and it simulates horizontal ground-water flow. The model considers a multilayered flow system consisting of alluvial, volcanic, and carbonate aquifers as one unit and simulates the most transmissive hydrostratigraphic unit(s) at any given location. Detailed calculations for estimating recharge were documented. Model-predicted distribution of hydraulic heads was reported, and a water balance for the region was calcuiated. 
A ground-water flow model was developed for the western part of the NTS and its vicinity by Feeney, Campana, and Jacobson (1987). This is a discrete-state compartment model, calibrated with the stable isotope deuterium. The model consists of nine aquifer subregions. The model simulations yield ground-water flow paths and flow volumes that are in relative agreement with earlier studies. Major recharge and discharge areas were identified, and recharge was estimated as a percentage of precipitation. Minimum ground-water residence times within the flow system were also determined. 


\section{RADIONUCLIDE MIGRATION IN THE UNDERGROUND ENVIRONMENT}

The total amount of radionuclides introduced into the underground environment must be known for estimating the temporal and spatial disposition of those nuclides, particularly those that were deposited in or came into contact with the ground water. Borg et a1. (1976) reported that, for 78 test events that either were detonated below the water table or had a cavity edge below the water table, the fission products deposited could only be approximated and that the amount of tritium deposited below or near the water table could be estimated within a factor of 2 or 3 .

The radionuclides are generally divided into refractory and volatile species; the refractory species (those with high boiling points) concentrated in the puddle glass near the cavity bottom, and the volatiles were distributed through the chimney. Relative solubility and leaching data for these materials were reported as scarce, but it was believed that 1) less than $1 \%$ of the radionuclides in the melt giass near the cavity bottom would be dis. solved; 2) much of the soluble long-lived radionuclide material in the chimney water would be adsorbed on the chimney rubble; and 3) most of the tritium would be mixed with chimney water over a year's time (Borg et al. 1976). A systematic approach to better quantify the distribution and possible migration of radionuclides from the underground tests was begun with the investigations and studies of the Radionuclide Migration (RNM) Project.

The Radionuclide Migration Project was initiated at the NTS in January 1974, under the sponsorship of the Nevada Operations Office of the U.S. Energy Research and Deve opment Administration (ERDA; now DOE). Organizations participating with the Nevada Operations Office were LLNL, LANL, Desert Research Institute, USGS, and selected support organizations. The purpose of the RNM Project was to provide and interpret data that would quantify the radionuclides that migrate away from underground nuclear explosion cavities and chimneys and to determine the time-distance relationships of such migrations under the conditions of the test. The information would then be applicable to hydrologic program studies relating to long-term safety with regard to contamination of water supplies both on the NTS and off. Such 
studies might provide a base for further studies relating to underground disposal of high-level radioactive waste.

One analysis of the ultimate disposition of ${ }^{90} \mathrm{Sr}$ and tritium produced by a hypothetical nuclear explosion was reported by Borg et al. (1976), who concluded that, under the assumptions used in the analysis, there was a need for additional investigation of the distribution of radionuclides near the underground explosions and of the radioisotopic content of the chimney water.

At the time of the report by Borg et a1. (1976), several field projects and studies related to past nuclear tests events were in progress at the NTS and had not yet reached a stage where published reports were available. These projects were identified by the name of the associated test events (e.g., Cambric, Starwort, and Almendro), and brief summaries were given by Borg et al. (1976). Since then, previously unpublished data have been compiled and published by LLNL (Buddemeier and Isherwood 1985) and by LANL (Hoffman, Stone, and Dudley 1977; Daniels and Thompson 1984). These reports include further data on some of the projects mentioned by Borg et a1. (1976), as well as data from several other radionuclide migration studies. Brief descriptions of the studies mentioned by Borg et al. (1976) and the results of the six studies published through 1984 that are listed by Buddemeier and Isherwood (1985) are given below. The studies described represent differing locations at the NTS, different materials at the shot-point depth, and different locations of the detonations with respect to the water table. Locations of the event sites at the NTS (except for Starwort and Faultless) are shown in Fig. 20.

Bilby (U3Cn): The Bilby event was fired on September 9, 1963. It was the first event detonated below the water table at the NTS (Buddemeier and Isherwood 1985). The event had a yield of approximately 200 kilotons and produced a cavity with a radius of about $265 \mathrm{ft}(B 7 \mathrm{~m})$. The working point (the depth at which the detonation occurred) was $2,173 \mathrm{ft}(712.9 \mathrm{~m}$ ) and located in the Indian Trail tuff, about $451 \mathrm{ft}(148 \mathrm{~m})$ above the top of the underlying Paleozoic carbonate rocks (Fig. 21). After the event, the 


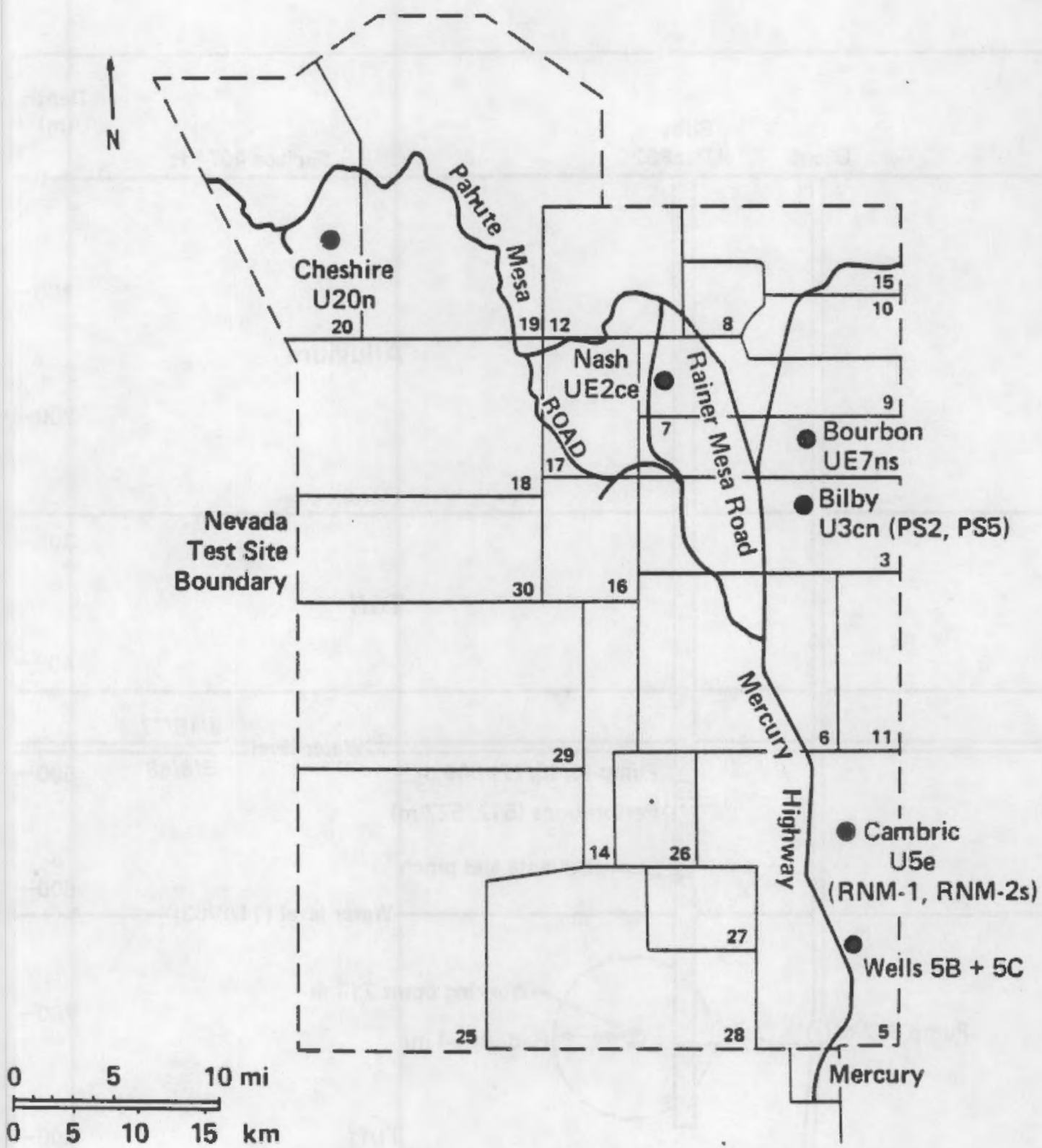

FIGURE 20. Locations of Experimental Sites Described in This Report. Small numbers indicate NTS Areas (after Buddemeier and Isherwood 1985). 


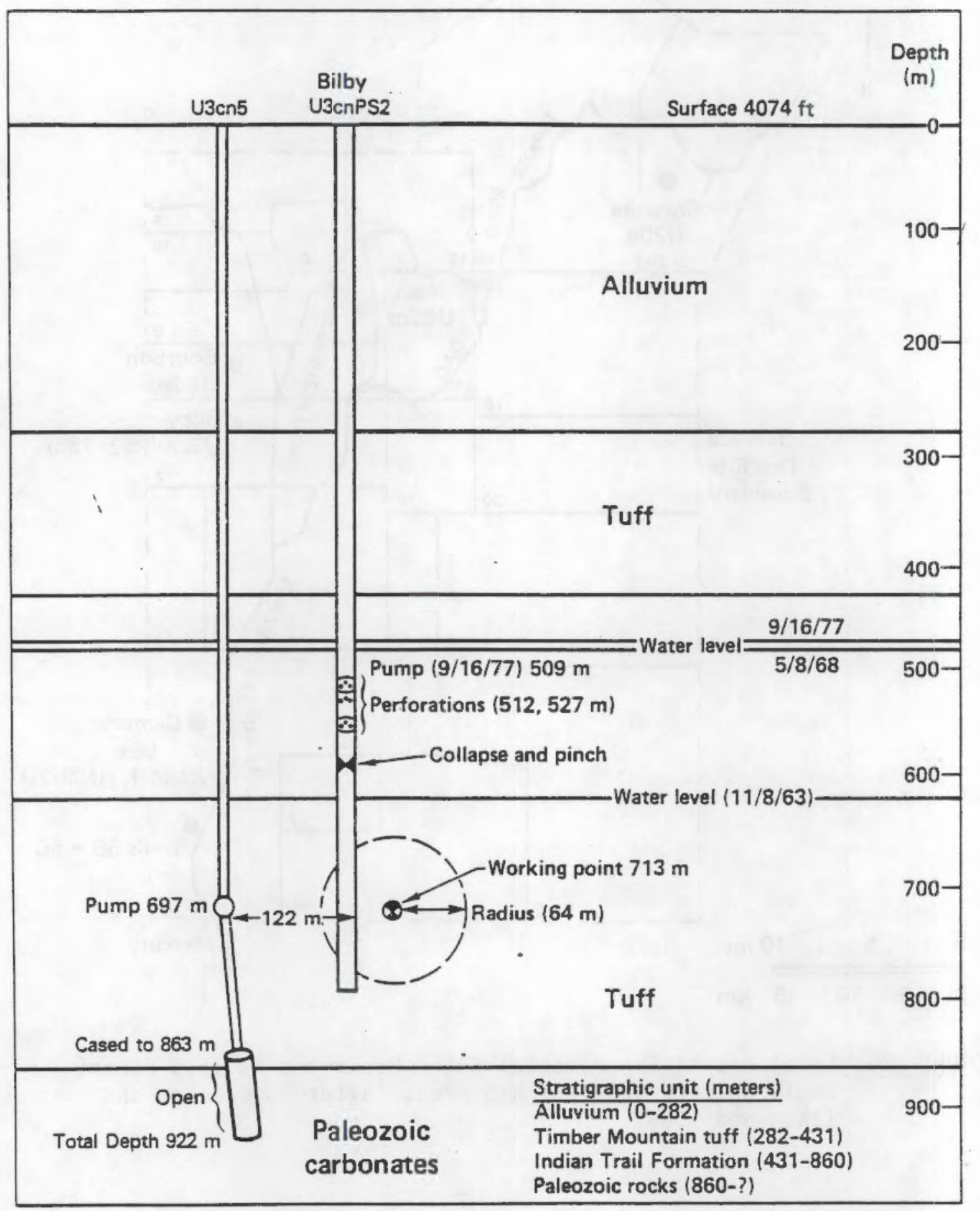

FIGURE 21. Bilby Site Cross Section (after Buddemeier and Isherwood 1985) 
chimney and cavity created by the blast began filling with ground water as the chimney collapsed and the water table returned to the pre-test elevation by the end of 1968 .

A reentry bore hole (U3cnPS2) was drilled September 23, 1963, to a depth of $2,418 \mathrm{ft}(793.4 \mathrm{~m})$ at a horizontal distance of $31 \mathrm{ft}(10 \mathrm{~m})$ from the working point. Less than two weeks later, the casing collapsed below the water table at $1,789 \mathrm{ft}(587 \mathrm{~m})$, and sampling could be done only from the chimney. Another well, a satellite well (U3cn5) lying $372 \mathrm{ft}$ (122 m) southeast of U3cnPS2, was begun in September 1965 and finished in February 1966. The satellite well was drilled into, and cased and cemented to produce water from, the Paleozoic carbonate aquifer. It is estimated that $1.07 \times 10^{9} \mathrm{ft}^{3}$ $\left(3.03 \times 10^{6} \mathrm{~m}^{3}\right)$ were pumped to induce flow toward U3cnPS2 and for water samples before the pump failed in 1981 (Buddemeier and Isherwood 1985).

The satellite well was monitored for more than 10 years without any radioactivity being detected, which suggests that the Paleozoic carbonate aquifer was not contaminated by the Bilby Event. However, the possibility of such contamination cannot be ruled out because of hydrologic uncertainties about fracture flow systems and the actual ground-water flow direction between the wells.

Cambric (U5e): The Cambric event was detonated with a yield of 0.75 kilotons on May 14, 1965. It is one of the most extensively documented events to occur at the NTS (Hoffman, Stone, and Dudley 1977). The working point was at a depth of $896 \mathrm{ft}(294 \mathrm{~m})$ in alluvium, and the water table was $223 \mathrm{ft}(73 \mathrm{~m})$ above the working point before the test (Fig. 22). A slanting reentry hole (RNM-1) was drilled through the cavity on June 20, 1974, with core, water, and gas-bearing samples taken at intervals. A satellite well (RNM-2S) was drilled in April 1974 with a horizontal distance of $277 \mathrm{ft}$ (91 $\mathrm{m})$ from the Cambric cavity. To induce flow from the cavity to the satellite well, a pump was installed in October 1975, being replaced by a larger pump in October 1977, and pumping that continues to the present was begun. Tritium breakthrough occurred in RNM-2S in December 1977, reached a maximum in July 1980, and has been decreasing since then. 


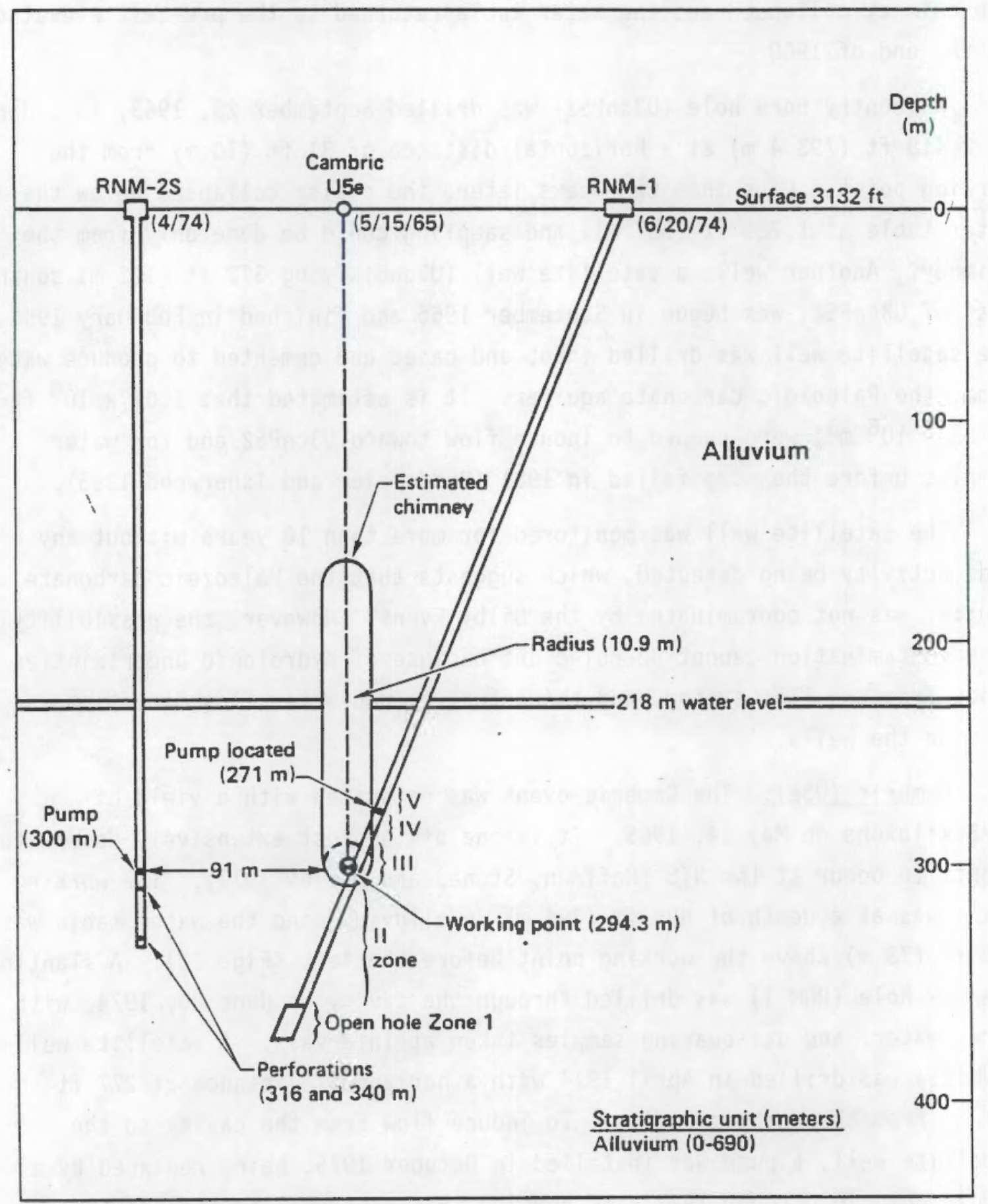

FIGURE 22. Cambric Site Cross Section (after Buddemeier and Isherwood 1985) 
In addition to tritium, ${ }^{85} \mathrm{Kr},{ }^{36} \mathrm{Cl}$, and ${ }^{129} \mathrm{I}$ have been detected, along with lesser amounts of ${ }^{106} \mathrm{Ru}$ and insignificant amounts of ${ }^{137} \mathrm{Cs}$. Data suggested that the ${ }^{106} \mathrm{Ru}$ activity correlated with tritium activity, which is at odds with observations at the Bilby chimney, where ${ }^{106}$ Ru activity decreased much more rapidly than tritium activity between 1977 and 1981 (Buddemeier and Isherwood 1985).

There is a question of whether the water pumped from RNM-2S and from RNM-1, which is discharged to an unlined ditch near the wellhead, may have recharged the water table over the course of the experiment. If this has occurred, RNM-2S may be pumping water that was partly recycled. Another study, the Cambric plume study, was initiated to investigate this question, but final results have not yet been published.

Starwort (U2bs): The Starwort event was an 85-kiloton nuclear explosion detonated in April 1973 in tuff at a depth of $1,719 \mathrm{ft}(564 \mathrm{~m}), 122 \mathrm{ft}(40 \mathrm{~m})$ below the water table, in Yucca Flat (Fig. 23). The project plan was to leave a strong casing in the post-test drill hole (U2bs PS\#1db) to sample water and record the chimney in-fill rate and temperature of the cavity. However, when the temperature had cooled to below the boiling point and in-fill was expected to begin, a nearby test in December 1975 sheared the casing. No further published information was found for this event.

Almendro (U19v): The Almendro event was detonated in ash-flow tuff at Pahute Mesa in June 1973, with the shot point at a depth of $3,243 \mathrm{ft}$ $(1064 \mathrm{~m})$, some $1,161 \mathrm{ft}(381 \mathrm{~m})$ below the water table. At the time of the Borg et al. (1976) report, the temperature had not cooled to a point low enough for the instruments to function. No further or more recent information has been published about this event.

Nash (UE2ce): The Nash event was detonated on January 19, 1967, with an announced yield in the 20- to 200-kiloton range. The working point was at a depth of $1,120 \mathrm{ft}(367.5 \mathrm{~m})$, about $204 \mathrm{ft}(67 \mathrm{~m})$ above the water table, and located in Paleozoic carbonate rocks (Fig. 24). The chimney collapsed shortly after detonation. A satellite well (UE2cd) was drilled approximately $558 \mathrm{ft}(183 \mathrm{~m})$ due south of UE2ce on January 25,1977 , to a depth of $1,533 \mathrm{ft}$ $(503 \mathrm{~m})$. 


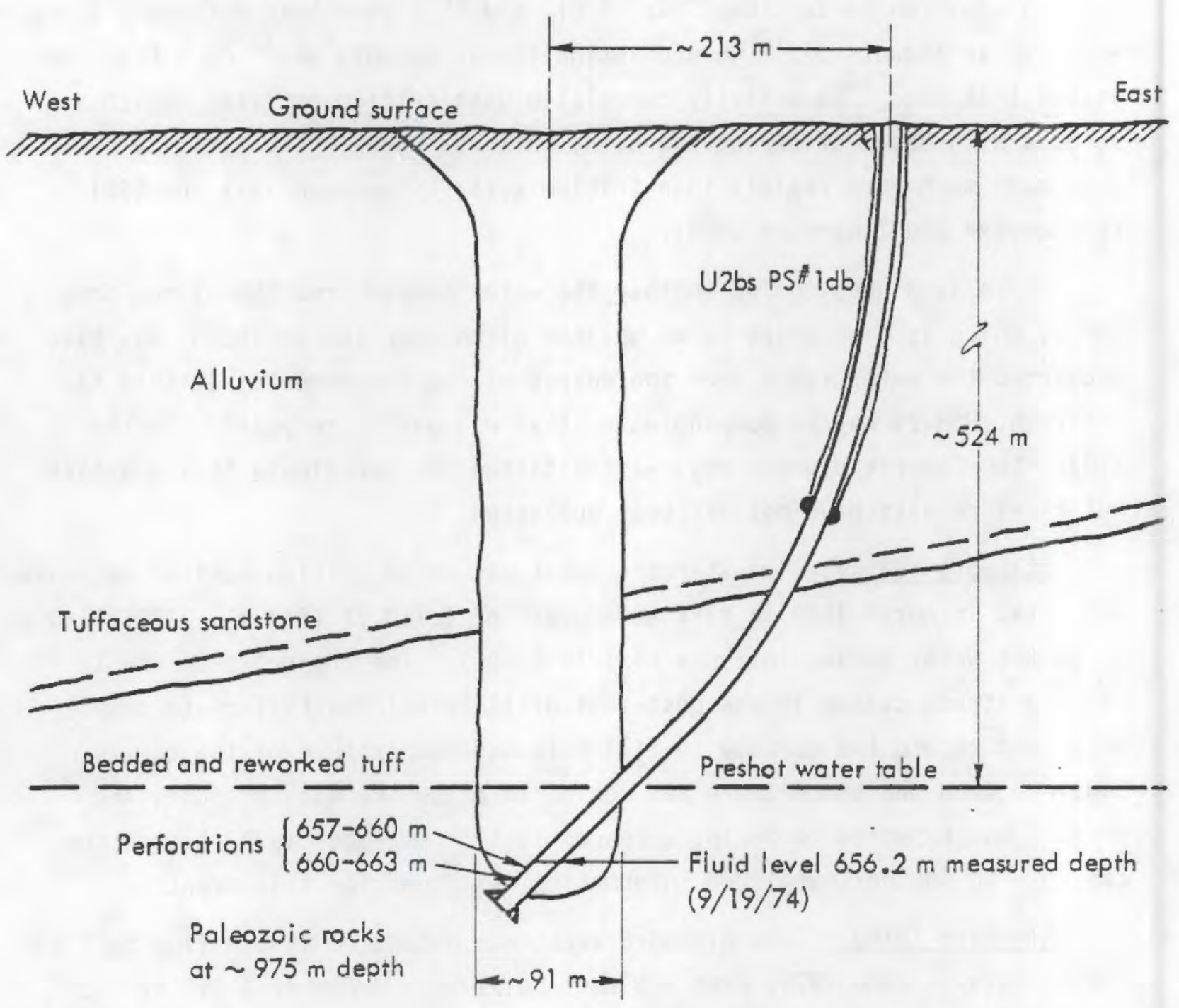

FIGURE 23. Starwort Site Cross Section (after Buddemeier and Isherwood 1985)

The general vicinity of UE2ce is a part of the NTS that has been heavily used for testing. Several detonations have been made within a 0.6 -mile (1-km) radius of the Nash Event and a substantial number within a slightly larger radius (Buddemeier and Isherwood 1985). It is not known whether this testing activity resulted in water-table fluctuations and temporary changes in rate and direction of ground-water flow at UE2ce.

Although there are uncertainties about the interaction between the test cavity and the ground-water system, this site is the only one for which contamination of the regionally important carbonate aquifer system had been 


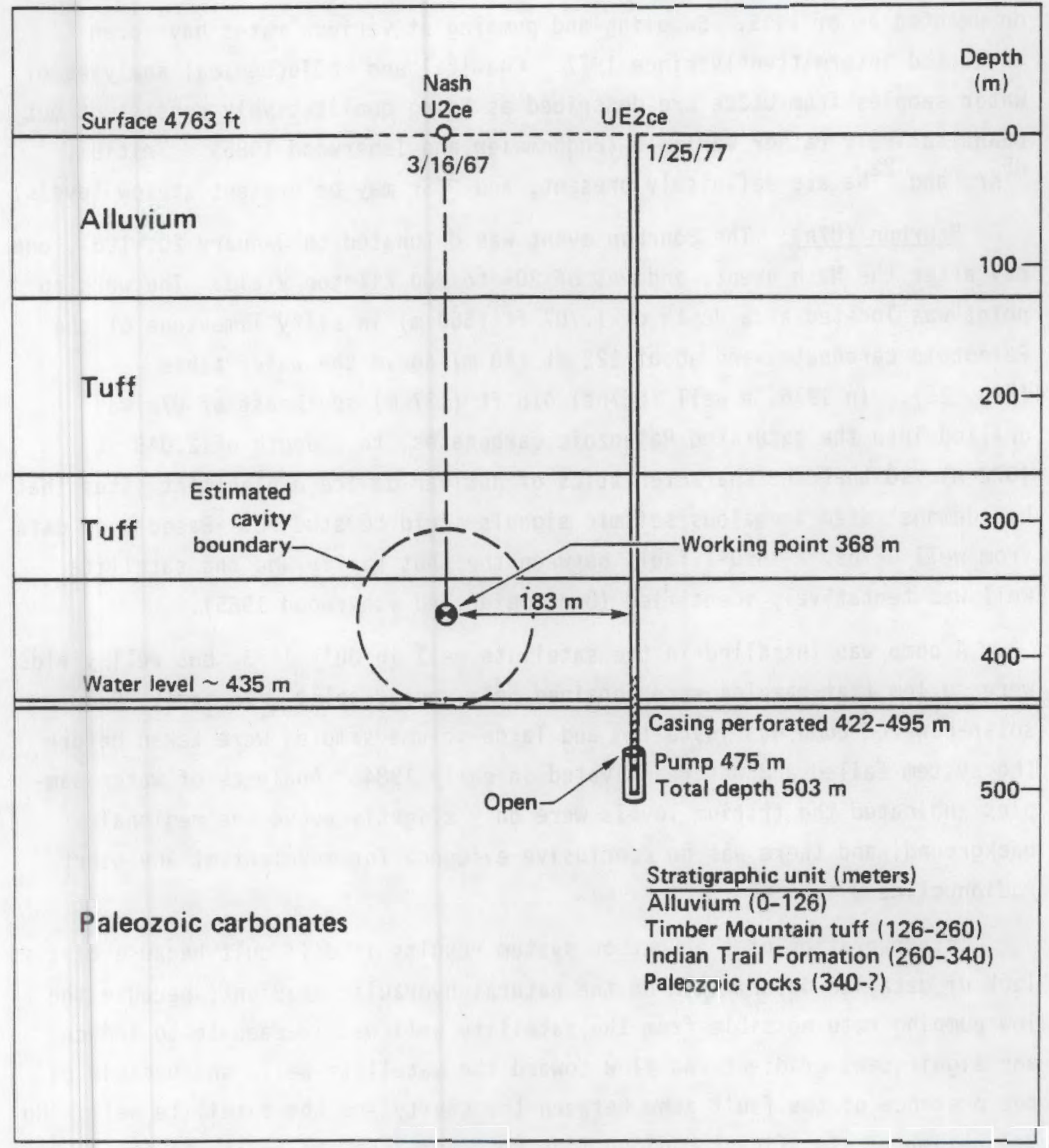

FIGURE 24. Nash Site Cross Section (after Buddemeier and Isherwood 1985) 
documented as of 1985. Sampling and pumping at various rates have been conducted intermittently since 1977. Chemical and radiochemical analyses of water samples from UE2ce are described as being qualitatively consistent but quantitatively rather variable (Buddemeier and Isherwood 1985). Tritium, ${ }^{85} \mathrm{Kr}$, and ${ }^{22} \mathrm{Na}$ are definitely present, and ${ }^{90} \mathrm{Sr}$ may be present at low levels.

Bourbon (U7n): The Bourbon event was detonated on January 20, 1967, one day after the Nash event, and was of 20- to 200-kiloton yield. The working point was located at a depth of $1,707 \mathrm{ft}(560 \mathrm{~m})$ in silty limestone of the Paleozoic carbonates and about $122 \mathrm{ft}(40 \mathrm{~m})$ above the water table (Fig. 25). In 1976, a well (UE7ns) $418 \mathrm{ft}(137 \mathrm{~m})$ southeast of U7n was drilled into the saturated Paleozoic carbonates, to a depth of 2,048 ft $(672 \mathrm{~m})$, so that the characteristics of nuclear-device emplacement sites that had demonstrated anomalous seismic signals could be studied. Based upon data from well UE7ns, a thrust fault between the shot cavity and the satellite well was tentatively identified (Buddemeier and Isherwood 1985).

A pump was installed in the satellite well in July 1973, but well yields were so low that samples were obtained only sporadically. In early 1983, a solar-powered pump was installed and large-volume samples were taken before the system failed and was reactivated in early 1984. Analyses of water samples indicated the tritium levels were only slightly above the regional background, and there was no conclusive evidence for movement of any other radionuclides.

Interpretation of the Bourbon system results is difficult because of the lack of detailed information on the natural hydraulic gradient, because the low pumping rate possible from the satellite well was inadequate to induce any significant gradient and flow toward the satellite well, and because of the presence of the fault zone between the cavity and the satellite well. No indication of significant radionuclide movement from the cavity to the satellite well was detected, and given the low pumping rates at the satellite well, it is unlikely that any further pumping and sampling will be done, unless routine monitoring shows a breakthrough of higher-activity water (Buddemeier and Isherwood 1985). 


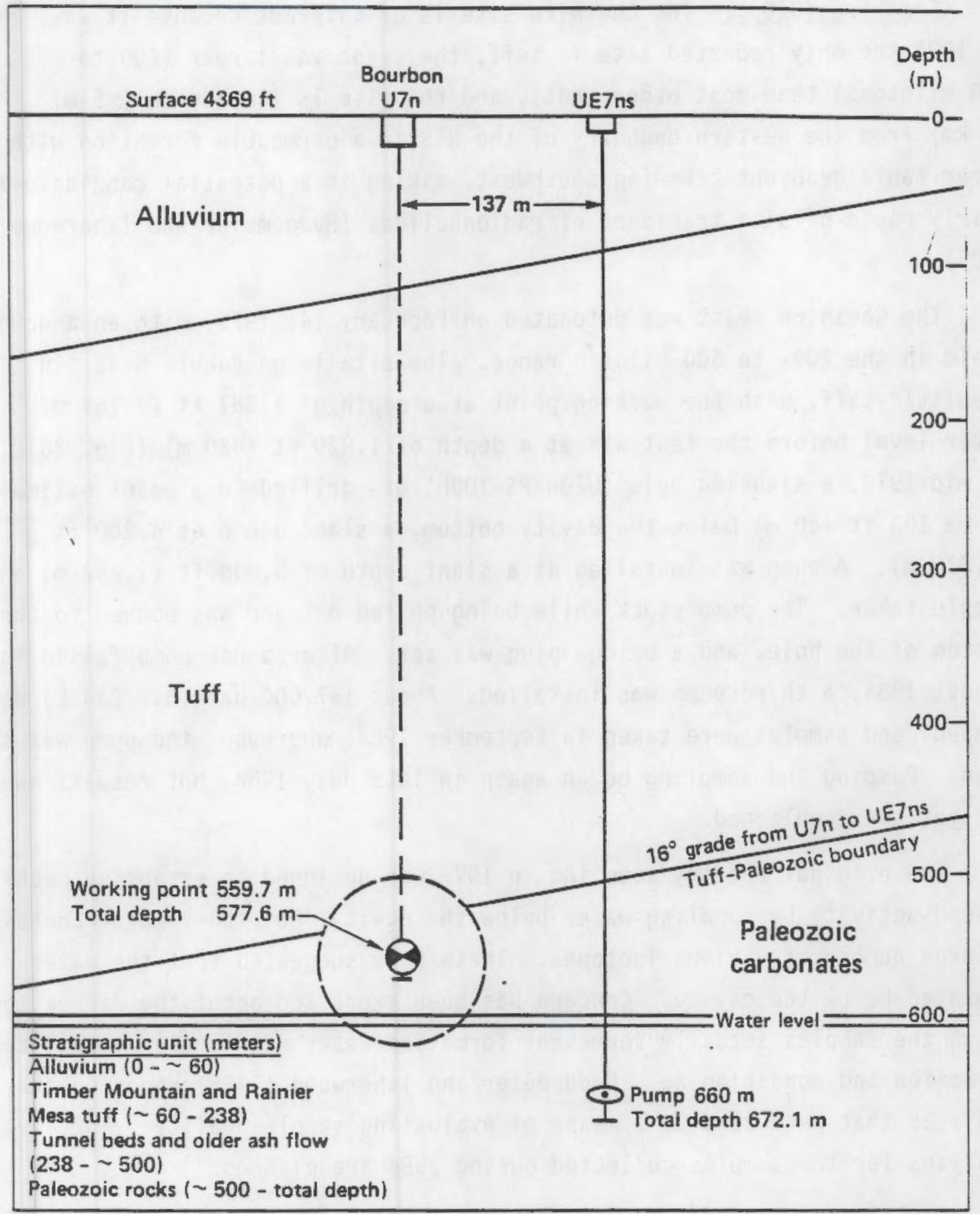

FIGURE 25. Bourbon Site Cross Section (after Buddemeier and Isherwood 1985) 
Cheshire (U2On): The Cheshire site is of interest because it was in 1984 the only reported site in tuff, the event was larger (200 to 500 kilotons) than most other shots, and the site is located only $5 \mathrm{mi}$ $(8 \mathrm{~km})$ from the western boundary of the NTS in a permeable formation with a water-table gradient trending southwest, making it a potential candidate for fairly rapid offsite transport of radionuclides (Buddemeier and Isherwood 1985).

The Cheshire event was detonated on February 14, 1976, with an announced yield in the 200- to 500-kiloton range. The site is on Pahute Mesa, in rhyolitic tuff, with the working point at a depth of $3,557 \mathrm{ft}(1,167 \mathrm{~m})$. The water level before the test was at a depth of $1,920 \mathrm{ft}(630 \mathrm{~m})$ (Fig. 26). In mid-1976, a slanting hole (U20n-PS-10Dh) was drilled to a point estimated to be $183 \mathrm{ft}(60 \mathrm{~m})$ below the cavity bottom, a slant depth of 4,200 ft $(1,378 \mathrm{~m})$. A pump was installed at a slant depth of $3,938 \mathrm{ft}(1,292 \mathrm{~m})$ and a sample taken. The pump stuck while being pulled out and was pushed to the bottom of the hole, and a bridge plug was set. After a new pump failed in August 1983, a third pump was installed. About $137,000 \mathrm{gal}(519,230 \mathrm{~L})$ were pumped, and samples were taken in September 1983, whereupon the pump was shut down. Pumping and sampling began again in late July 1984, but results have not yet been published.

The original reentry sampling in 1976 was designed to establish background activity by sampling water below the cavity, but the samples contained a large number of various isotopes. These data suggested that the water had migrated below the cavity. Concern has been expressed about the degree to which the samples actually represent formation water unaffected by well construction and conditioning. Buddemeier and Isherwood (1985) reported the analyses that were used as a means of evaluating sample quality. Further analyses for the samples collected during 1984 are planned.

Faultless (UC1P2SR): The Faultless event was detonated on January 19, 1968 , with a yield of $200-1,000$ kilotons. The working point was at a depth of $2,973 \mathrm{ft}(975.4 \mathrm{~m})$ in unwelded tuff, with the preshot water level at $520 \mathrm{ft}(170.7 \mathrm{~m})$. This is the only event reported in the RNM Program that took place off the NTS, in Hot Creek Valley, Central Nevada. A drillback 


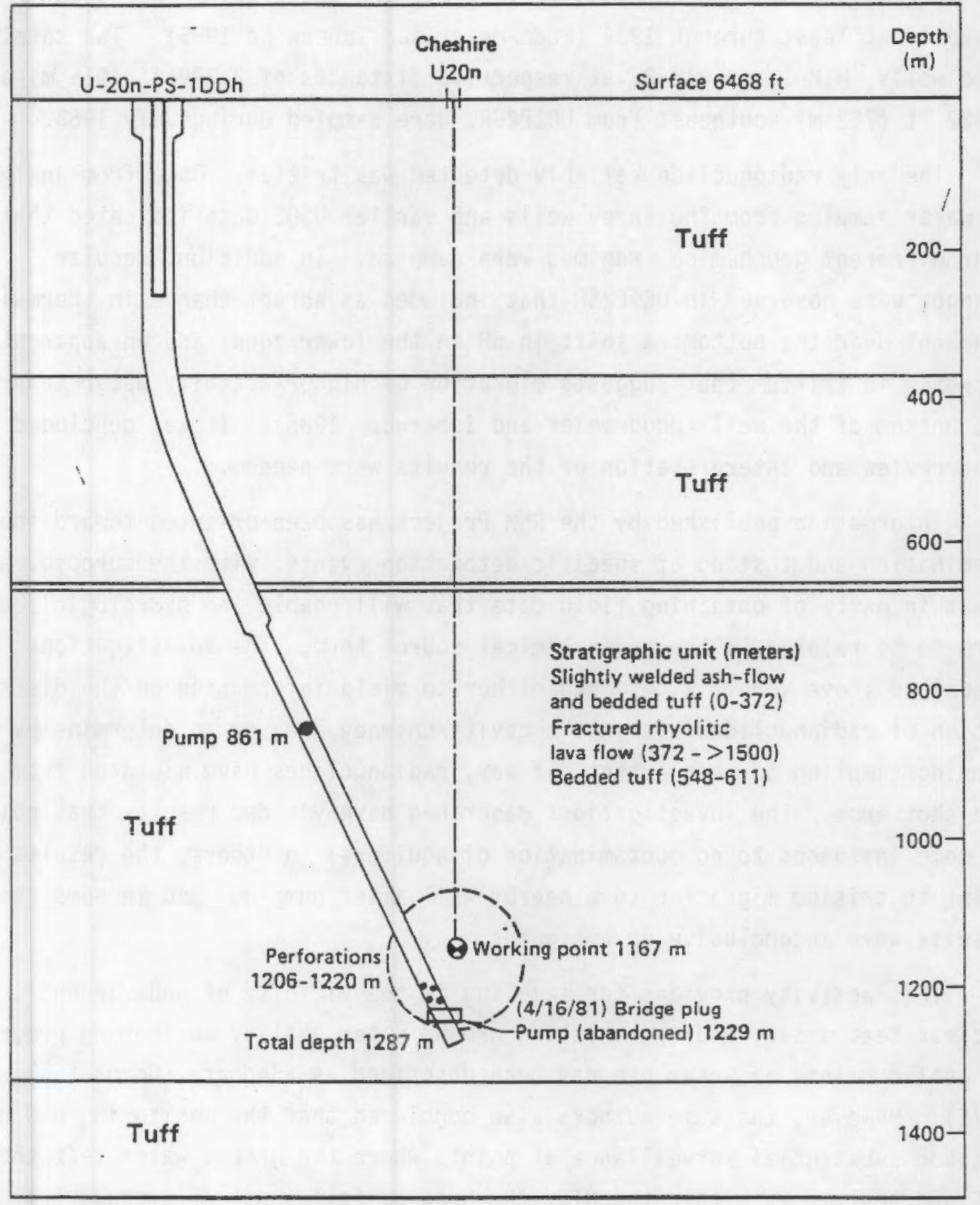

FIGURE 26. Cheshire Site Cross Section (after Buddemeier and Isherwood 1985) 
hole (P2SR) was drilled to 2,444 ft $(802 \mathrm{~m})$, and water level increased steadily at least through 1984 (Buddemeier and Isherwood 1985). Two satellite we11s, HTH-1 and HTH-2, at respective distances of 2,789 ft (915 m) and 2,322 ft $(762 \mathrm{~m})$ southeast from UC1P2SR, were sampled during July 1983.

The only radionuclide reliably detected was tritium. Data from analyses of water samples from the three wells and eariier USGS data indicated that four different geochemical regimes were sampled. In addition, secular changes were observed in UC1P2SR that included an abrupt change in thermal gradient near the bottom; a shift in $\mathrm{pH}$ in the lower zone; and an apparent increase in tritium that suggests migration of higher-activity water toward the bottom of the well (Buddemeier and Isherwood 1985). It was concluded that review and interpretation of the results were needed.

Information published by the RNM Project has been oriented toward the examination and testing of specific detonation events, with the purpose, at least in part, of obtaining field data that will enable the hydrologic source term to be related to the radiochemical source term. The investigations described above were all designed either to yield information on the distribution of radionuclides within the cavity/chimney area or to determine by pumping/sampling to what extent, if any, radionuclides have migrated from the shot area. The investigations described have yielded results that point in some instances to no contamination of aquifers; in others, the results point to tritium migration to a nearby well after pumping, and in some the results were inconclusive or ambiguous.

This activity provides for sampling in the vicinity of underground nuclear test areas, and the existing ground-water quality monitoring program at public points of water use has been described as adequate (Borg et al. 1976). However, the same authors also concluded that the monitoring did not include substantial surveillance at points where the ground water left the NTS and that, even within the NTS, the program fell short of a concerted effort to chart the movement of radioactive water from sources of contamination. Information published since 1976 indicates that these conclusions are still essentially valid. 


\section{GROUND-WATER QUALITY MONITORING AT AND NEAR THE NTS}

The ground-water monitoring program for the NTS has been described by Borg et a1. (1976). The program is operated by the U.S. Environmental Protection Agency (EPA) under direction of the Physical Sciences Division, Nevada Operations Office, originally under ERDA. In 1976, there were 31 ground-water sampling points in the program, with a density of about 1 per $78 \mathrm{mi}^{2}\left(200 \mathrm{~km}^{2}\right)$. Most of the sampling points were existing water-supply wells and springs, with 17 located within the NTS. The locations of the ground-water sampling points with respect to the NTS are shown in Fig. 27. At present, it is not known if this sampling network has been modified.

Nine of the points in the network are sampled monthly; the remainder are sampled semiannually (Borg et al. 1976). Each sample is analyzed for tritium and receives a gamma spectral examination. If fission products are detected, analyses are performed for ${ }^{89,90} \mathrm{Sr},{ }^{15 l_{\mathrm{Sm}}, 238,239,240} \mathrm{Pu}$, and ${ }^{234,235,238} \mathrm{U}$ by chemical separation and beta counting or alpha spectroscopic analysis.

No radioactive contamination of ground water had been recognized at sampling points of the monitoring network at the time of the report by Borg et a1. (1976). Tritium had been detected in concentrations above that of uncontaminated water in samples from two locations in Area 2 of Yucca Flat in 1974 and 1975. Water from one of these locations contained tritium in concentrations more than three times greater than the maximum permissibie concentration (MPC), and water from the second location contained tritium at levels that were below the MPC but higher than the baseline for ground water in the area. The well locations were not clearly specified by Borg et al. (1976) but were described as being separated laterally by 1,372 ft (450 m) and $1,006 \mathrm{ft}(330 \mathrm{~m})$, respectively, from the nearest sites where nuclear explosions had been conducted below the water table.

The Desert Research Institute (DRI) investigated certain parameters of drinking water quality for DOE at 11 locations in the Amargosa Desert, Nevada and California (E1liott 1982). The area of interest is located west and 


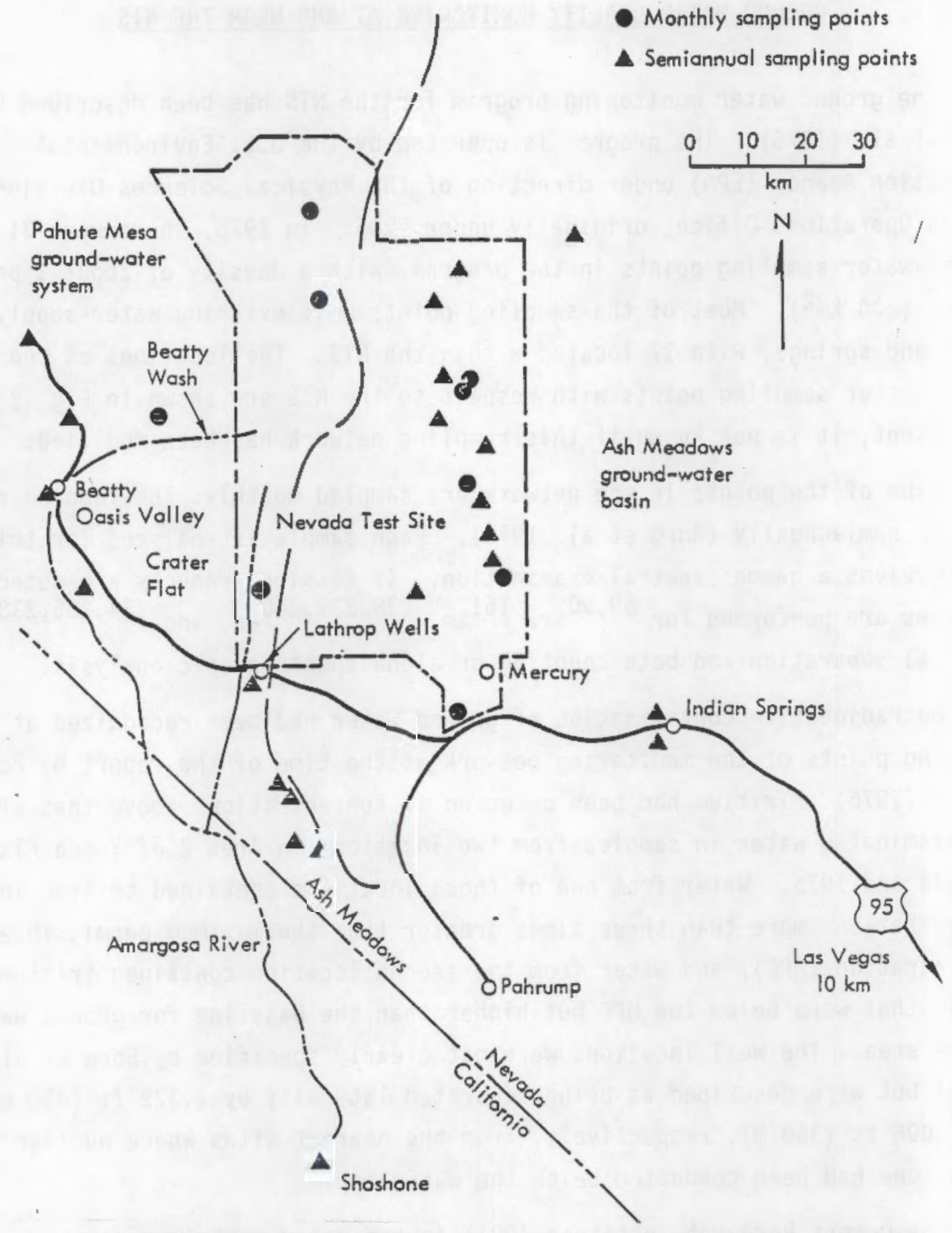

FIGURE 27. Map of the NTS and Vicinity Showing the Monthly and Semiannual Ground-Water Quality Monitoring Network (after Borg et a1. 1976) 
south of the NTS and contains flow paths and discharge locations for ground water draining from the NTS. Locations of the sample sites are shown in Fig. 28. Samples were analyzed for inorganic chemical constituents and radioactivity. Results of the analyses of drinking water samples collected indicated no excess concentrations of radioactivity, and no contamination from the NTS was observed in any of the samples collected (Elliott 1982).

Borg et al. (1976) described the monitoring program as adequate at points of public use and as providing for sampling in the vicinity of underground nuclear test areas, but not including substantial surveillance at points where the ground water leaves the confines of NTS; within NTS, they found that the program fell short of a concerted effort to chart the movement of radioactive ground water from sources of contamination. More recent published literature does not indicate that these statements are not still essentially valid. 


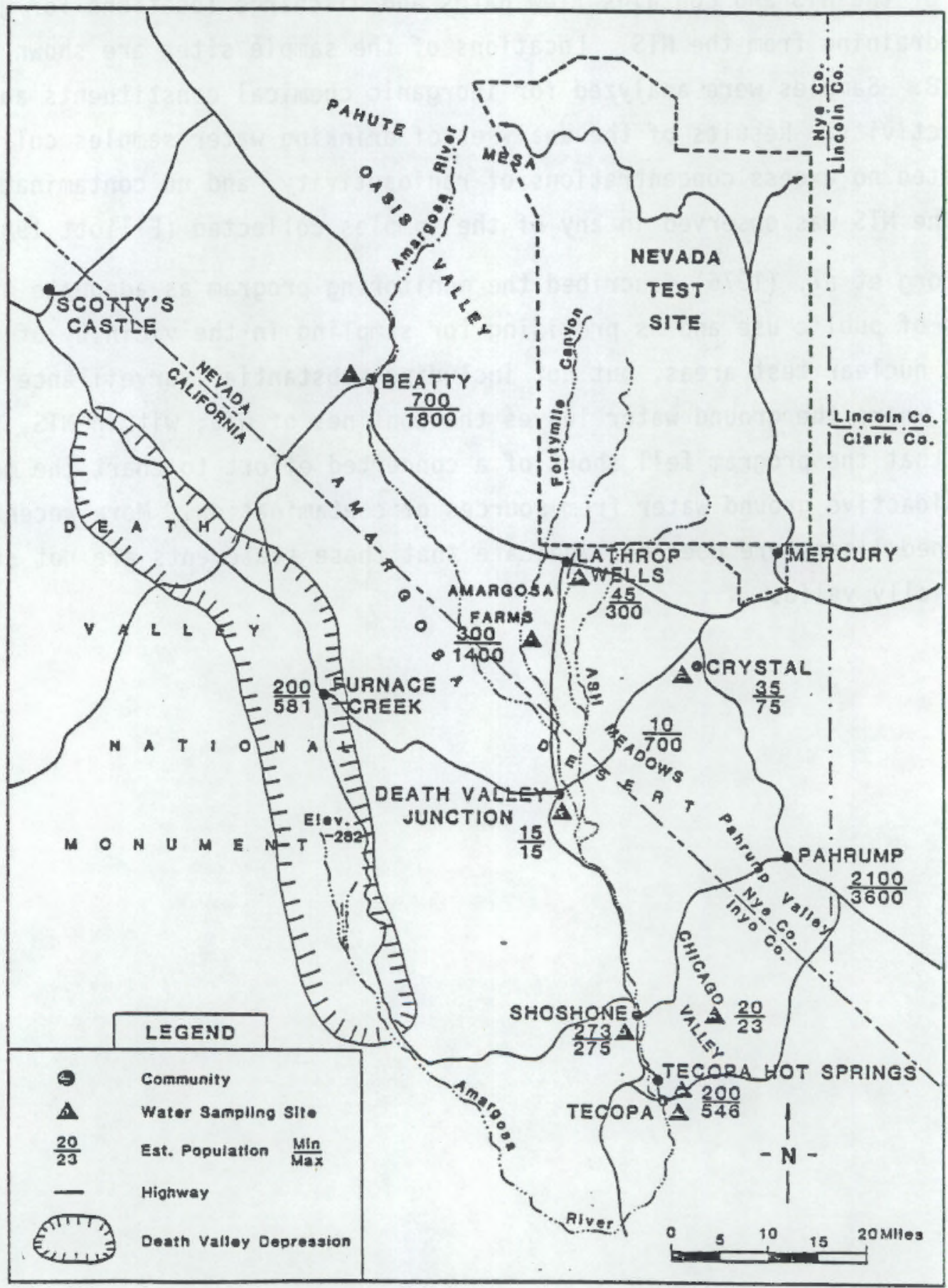

FIGURE 28. Location of Water Sampling Sites - Desert Research Institute, 1982 (after Elliott 1982) 


\section{REFERENCES}

Barnes, H., R.L. Christiansen, and F.M. Byers, Jr. 1965. Geologic Map of the Jangle Ridge Ouadrangle, Nye and Lincoln Counties, Nevada. U.S. Geological Survey Geologic Quadrangle Map GQ-363, Scale 1:24,000, U.S. Geological Survey, Denver, Colorado.

Barr, G.E. 1985. Reduction of the Well Test Data for Test Well] USW H-1, Adjacent to NTS, Nye County, Nevada. SAND84-0637, Sandia National Laboratories, Albuquerque, New Mexico.

Bath, G.D., and C.E. Jahren. 1984. Interpretations of Magnetic Anomalies at Repository Site Proposed for Yucca Mountain Area, Nevada Test Site. USGSOFR-84-120, U.S. Geological Survey, Denver, Colorado.

Benson, L.V., J.H. Robison, R.K. Blankennagel, and A. E. Ogard. 1983. Chemical Composition of Ground Water and the Locations of Permeable Zones in the Yucca Mountain Area, Nevada. USGS-0FR-83-854, U.S. Geological Survey, Denver, Colorado.

Bentley, C.B. 1984. Geohydrologic Data for Test Wel1 USW G-4, Yucca Mounta in Area, Nye County, Nevada. USGS-0FR-84-063, U.S. Geological Survey, Denver, Colorado.

Bentiey, C.B., J.H. Robison, and R.W. Spengler. 1983. Geohydrologic Data for Test Well USW H-5, Yucca Mounta in Area, Nye County, Nevada. USGS-OFR83-853, U.S. Geological Survey, Denver, Colorado.

Bish, D.L., D.T. Vaniman, F.M. Byers, Jr., and D.E. Broxton. 1982. Summary of the Mineralogy-Petrology of Tuffs of Yucca Mountain and the SecondaryPhase Thermal Stability in Tuffs. LA-9321-MS, Los ATamos National Laboratory, Los Alamos, New Mexico.

Blankennage1, R.K., and J.E. Weir. 1973. Geohydrology of the Eastern Part of Pahute Mesa, Nevada Test Site, Nye County, Nevada. Professional Paper $712-B$, U.S. Geological Survey, Washington, D.C.

Borg, I.Y. 1975. "Radioactivity Trapped in Melt Produced by a Nuciear Explosion." Nuclear Technology 26:88-100.

Borg, I.Y., R. Stone, H.B. Levy, and L.D. Ramspott. 1976. Information Pertinent to the Migration of Radionuclides in Ground Water at the Nevada Iest Site, Part 1: Review and Analys is of Existing Information. UCRL-52078, Lawrence Livermore National Laboratory, Livermore, California.

Bracken, R.E., and M.F. Kane. 1983. Complete Bouguer Gravity Map of Nevada, Kingman Sheet. Scale 1:250,000, Nevada Bureau of Mines and Technology, Carson City, Nevada. 
Buddemeier, R.W., and D. Isherwood. 1985. Radionuclide Migration Project 1984 Progress Report. UCRL -53628 , Lawrence Livermore National Laboratory, Livermore, Ca]ifornia.

Byers, F.M., Jr., and W.L. Hawkins. 1981. Geology of Drill Hole Uel8t and Area 18, Timber Mountain Caldera Moat, NTS. USGS-474-312, U.S. Geological Survey, Denver, Colorado.

Byers, F.M., Jr., W.J. Carr, R.L. Christiansen, P.W. Lipman, P.P. Orkild, and W.D. Quintivan. 1976a. Geologic Map of the Timber Mountain, Caldera Area. Nye County, Nevada. MAP I-891, U.S. Geological Survey, Reston, Virginia.

Byers, F.M., Jr., W.J. Carr, P.P. Orkild, W.D. Quinlivan, and K.A. Sargent. 1976b. Volcanic Suites and Related Cauldrons of Timber Mountain-0asis Valley Caldera Complex, Southern Nevada. Professional Paper 919, U.S. Geological Survey, Denver, Colorado.

Carroil, R.D., and J.E. Kibler. 1983. Sourcebook of Locations of Geophysical Surveys in Tunnels and Horizontal Holes, Including Results of Seismic Refraction Surveys, Rainier Mesa, Aqueduct Mesa, and Area 16, Nevada Test Site. USGS-OFR 83-399, U.S. Geological Survey, Denver, Colorado.

Case, C., J. Davis, R. French, and S. Raker. 1984. Site Characterization in Connection with the Low Level Defense Waste Manaqement Site in Area 5 of the Nevada Test Site, Nye County, Nevada--Final Report. DOE/NV/10162-13, Water Resources Center, Desert Research Institute, University of Nevada System, Las Vegas, Nevada.

Christiansen, R.L., P.W. Lipman, W.J. Carr, F.M. Byers, Jr., P.P. Orkild, and K.A. Sargent. 1977. "Timber Mountain-Oasis Valley Caldera Complex of Southern Nevada." Geologica? Society of America Bulletin 88:943-959.

Claassen, H.C. 1983. Sources and Mechanisms of Recharge for Ground-Water in the West-Central Amargosa Desert, Nevada--A Geochemical Interpretation. USGS-0FR-83-542, U.S. Geological Survey, Denver, Colorado.

Claassen, H.C. 1985. Sources and Mechanisms of Recharge for Ground Water in the West-Central Amargosa Desert, Nevada - A Geochemical Interpretation. Professional Paper 712-F, U.S. Geological Survey, Denver, Colorado.

Claassen, H.C., and E.H. Cordes. 1975. "Two-Wel] Recirculating Tracer Test in Fractured Carbonate Rock, Nevada." Hydrological Sciences Bulletin 20(3).

Cornwa11, J.R. 1972. Geology and Mineral Deposits of Southern Nye County. Nevada. Bulletin 77, Mackay School of Mines, University of Nevada, Reno, Nevada.

Craig, R.W., and K.A. Johnson. 1984. Geohydrologic Data for Test Well UE-25p.1. Yucca Mountain Area, Nve County, Nevada. USGS-OFR-84-450, U.S. Geological Survey, Denver, CoTorado. 
Craig, R.W., R.L. Reed, and R.W. Spengier, 1983. Geohydrologic Data for Test Well USW H-6 Yucca Mounta in Area, Nye County, Nevada. USGS-0FR-83-856, U.S. Geological Survey, Denver, Colorado.

Crowe, B.M., and W.J. Carr. 1980. Preliminary Assessment of the Risk of Volcanism at a Proposed Nuclear Waste Repository in the Southern Great Basin. USGS-0FR-80-357, U.S. Geological Survey, Denver, Colorado.

Czarnecki, J.B. 1985. Simulated Effects on Increased Recharge on the Ground-Water Flow System of Yucca Mountain and Vicinity Nevada-Cal ifornia. Water Resources Investigations Report 84-4344, U.S. Geologicai Survey, Denver, Colorado.

Czarnecki, J.B., and R.K. Wadde 31. 1984. Finite-Element Simulation of Ground-Water Flow in the Vicinity of Yucca Mountain, Nevada-California. Water Resources Investigations Report 84-4349, U.S. Geologica? Survey, Denver, Colorado.

Daniels, W.R., and J.L. Thompson. 1984. Laboratory and Fieid Studies Related to the Radionuclide Migration Project; October 1, 1982 - September 30, 1983. LA-1012l-PR, Los Al amos National Laboratory, Los Alamos, New Mexico.

Daniels, J.J., J.H. Scott, and J.T. Hagstrum. 1981. Interpretation of Geophysical We]1-Log Measurements in Drill Holes UE25a-4,-5, -6 , and -7 , Yucca Mountain. Nevada Test Site. USGS-0FR-81-615, U.S. Geological Survey, Denver, Colorado.

Doty, G.C., and W. Thordarson. 1983. Water Table in Rocks of Cenozoic and Paleozoic Age, 1980, Yucca Flat, Nevada Test Site, Nevada. Water Resources Investigations Report 83-4067, U.5. Geological Survey, Lakewood, Colorado.

Eakin, T.E., S.L. Schoff, and P. Cohen. 1963. Regional Hydrology of a Part of Southern Nevada: A.Reconnaissance. TEI-B33, U.S. Geological Survey, Denver, Colorado.

Ege, J.R., R.D. Carroll, J.E. Magner, and D.R. Cunningham. 1980. U.S.G.S. Investigations in the U12n.03 Drift, Rainier Mesa, Area 12, NTS. USGS-OFR80-1074, U.S. Geological Survey, Denver, Colorado.

Ege, J.R., W. Danilchik, and C.T. Feazel. 1980. Geology of the U12n.02 Drift, and Postshot 0bservations, Rainier Mesa, Area 12, NIS. USGS-474-229, U.S. Geological Survey, Denver, Colorado.

Ekren, W.B. 1968. "Geologic Setting of Nevada Test Site and Nellis Air Force Range." In Nevada Test Site, ed. E.B. Eckel, pp. Il-19. Memoir 110, Geological Society of America, Denver, Colorado. 
Ekren, E.B., C.L. Rogers, R.E. Anderson, and.P.P. Drkild. 1968. "Age of Basin and Range Normal Faults in Nevada Test Site and Nell is Air Force Ranges, Nevada." In Nevada Test Site, ed. E.B. Ecke1, pp. 247-250. Memoir 110, Geological Society of America, Denver, Colorado.

Ekren, E.B., P.P. Orkild, K.A. Sargent, and G.L. Dixon. 1977. Geologic Map of Tertiary Rocks, Lincoln County. Nevada. Miscellaneous Investigations Map I-1041, Scale 1:24,000, U.S. Geological Survey, Denver, Colorado.

Elliott, B. 1982. An Investigation of Selected Water Quality Parameters in the Amarqosa Drainage Basin. DDE/NV/10162-18, Water Resources Center, Desert Research Institute, University of Nevada System, Las Vegas, Nevada.

Emerick, W.L. 1961. Summary of the Lithology of the U3ah Site, NTS. USGS Tech. Letter Yucca-3 Suppl. 1. U.S. Geological Survey, Washington, D.C.

Fairer, G.M., D.R. Townsend, R.D. Carroll, M.J. Cunningham, D.C. Muller, D.L. Healey, and W.L. Ellis. 1979. U.S.G.S. Investigations in Connection with the Mighty Epic Event, U12n.10 Tunnel, Nevada Test Site. USGS-474-228, U.S. Geological Survey, Denver, Colorado.

Feeney, T.A., M.E. Campana, and R.L. Jacobson. 1987. A Deuterium-Calibrated Groundwater Flow Model of the Western Nevada Test Site and Vicinity. DOE/NV/10384-16, Desert Research Institute, University of Nevada System, Las Vegas, Nevada.

Fenske, P.R. 1978. Interaquifer Leakage Through Uncased Boreholes Penetrations, Yucca Valley, NTS. NVO-1253-13, Desert Research Institute, University of Nevada System, Las Vegas, Nevada.

Fenske, P.R., and C.L. Carnahan. 1975. Water Table and Related Maps for NTS and Central Nevada Test Area. NV0-1253-9, Water Resources Center, Desert Research Institute, University of Nevada System, Las Vegas, Nevada.

Fouty, S. C. 1984. Index to Published Geologic Maps in the Region Around the Potential Yucca Mountain Nuclear Waste Repository Site, Southern Nye County, Nevada. USGS-0FR-84-525, U.S. Geological Survey, Denver, Colorado.

Gard, L.M., Jr. 1972. Chemical Analys is of Igneous Rocks from Drill Holes and Outcrops, Amchitka Island, Alaska, (including Working-Point Rocks of Longshot, Milrow and Cannikin). USGS-474-140, Amchitka-31, U.S. Geological Survey, Washington, D.C.

Gibbons, A.B., E.N. Hinrichs, D.D. Dickey, F.A. Mckeown, F.G. Poole, and F. N. House. 1959. Engineering Geology of Test Sites in Granite and Dolomite at Gold Meadows Climax and Dolomite Hill, NTS, Nye County, Nevada. USGS Trace Element Memorandum Report 888, U.S. Geological Survey, Washington, D.C.

Hansen, D.S. 1978. Tritjum Movement in the Unsaturated Zone, Nevada Test Site. University of Nevada, Reno, Nevada. 
Hanson, J.M. 1984. Barometric Pressure Transient Testing Applications at the NTS: Formation Permeability Analysis. UCRL-15699, Lawrence Livermore National Laboratory, Livermore, California.

Hanson, J.M. 1985. Barometric Pressure Transient Testing Applications at the NTS: Nuclear Chimney Analysis. UCRL-155770, Lawrence Livermore National Laboratory, Livermore, California.

Healey, D.L., F.G. Clutsom, and D.A. Glover. 1984. Borehole Gravity Meter Surveys in Drill Holes USW G-3, UE-25P\#1 and UE-25c\#1, Yucca Mountain Area, Nevada. USGS-0FR-84-672, U.S. Geological Survey, Denver, Colorado.

Hoffman, D.C., R. Stone, and W.W. Dudiey, Jr. 1977. Radioactivity in the Underground Environment of the Cambric Nuclear Explosion at the NTS. LA-6877-m:s, Los Alamos National Laboratory, Los Alamos, New Mexico.

Hoover, D.L., H.C. Swadley, and A.J. Gordon. 1981. Correlation Characteristics of Surficial Deposits with a Description of Surficial Stratigraphy in the Nevada Test Site Region. USGS-OFR-81-512, U.S. Geological Survey, Denver, Colorado.

Jennings, C.W. 1977. Geologic Map of California. California Geologic Data Map Series, Scale 1:750,000, California Division of Mines and Geology, Sacramento, California.

Johnstone, J.K., and K. Wolfsberg. 1980. Evaluation of Tuff as a Medium for a Nuclear Waste Repository: Interim Status Report on the Properties of Tuff. SAND80-1464, Sandia National Laboratories, Albuquerque, New Mexico.

Kearl, P.M. 1982. Water Transport in Desert Alluvial Soil. D0E/NV/10162-2, Water Resources Center, Desert Research Institute, University of Nevada System, Las Vegas, Nevada.

Lahoud, R.G., D.H. Lobmeyer, and M.S. Whitfield, Jr. 1984. Geohydrology of Volcanic Tuff Penetrated By Test We11 UE-25b \#1, Yucca Mountain, Nye County, Nevada. Hater Resources Investigations Report 84-4253, U.S. Geological Survey, Denver, Colorado.

Langkopf, B.S., and E. Eshom. 1982. Site Exploration for Rock-Mechanics Field Tests in the Grouse Canyon Member, Belted Range Tuff, Ul2q Tunnel Complex NTS. SAND81-1897, Sandia National Laboratories, Albuquerque, New Mexico.

Lobmeyer, D.H., M.S. Whitfield, Jr., R.G. Lahoud, and L. Bruckheimer. 1983. Geohydrologic Data for Test Wel1 UE-25b\#1 NTS, Nye County, Nevada.

USGS-0FR-83-855, U.S. Geological Survey, Washington, D.C.

Longwe11, C.R. 1960. "Possible Explanation of Diverse Structural Patterns in Southern Nevada." American Journal of Science 258-A:192-203. 
Longwel1, C.R., E.H. Pampeyan, and B. Bowyer. 1965. Geologic Map of Clark County, Nevada. Bulletin 62, Nevada Bureau of Mines, Carson City, Nevada.

Maldonado, F. 1984. Bedrock Geologic Map of the Lone Mounta in Pluton Area, Esmeralda County, Nevada. MAP I-1533, U.S. Geological Survey, Denver, Colorado.

Maldonado, F., and S.L. Koetcher. 1983. Stratigraphy, Structure and Some Petrographic Features of Laotians Volcanic Rocks at the USW G-2 Drill Hole, Yucca Mountain, Nye County. Nevada. USGS-0FR-83-732, U.S. Geological Survey, Denver, Colorado.

Maldonado, F., D.C. Muller, and J.N. Morrison. 1979. Preliminary Geologic and Geophysical Data of the UE25a-3 Exploratory Drill Hole, Nevada Test Site, Nevada. USGS-1543-6, U.S. Geological Survey, Denver, Colorado.

Maldonado, F., S.G. Steele, and D.R. Townsend. 1979. Supplementary Lithologic Logs of Selected Vertical Dri11 Holes in Area 12, NTS. USGS-474-261, U.S. Geological Survey, Denver, Colorado.

Metcalf, L.A. 1983a. A Preliminary Review and Summary of the Potential for Tectonic, Seismic, and Volcanic Activity at the Nevada Test Site Defense Waste Disposal Site. DOE/NV/10162-7, Water Resources Center, Desert Research Institute, University of Nevada System, Las Vegas, Nevada.

Metcalf, L.A. 1983b. Tephrostratigraphy and Potassium-Argon Aqe Determinations of Seven Volcanic Ash Layers in the Muddy Creek Formation of Southern Nevada. DOE/DP/10162-23, Desert Research Institute, University of Nevada System, Las Vegas, Nevada.

Montazer, P., and W. E. Wilson. 1984. Conceptual Hydrologic Model of Flow in the Unsaturated Zone, Yucca Mountain, Nevada. Water Resources Investigations Report 84-4345, U.S. Geological Survey, Denver, Colorado.

Muller, D.C., and J.E. Kibler. 1983. Commercial Geophysical Well Logs from the USW G-l Drill Hole, Nevada Test Site, Nevada, USGS-0FR-83-321, U.S. Geological Survey, Denver, Colorado.

Murray, W.A. 1981. Geohydrology of the Climax Stock Granite and Surrounding Rock Formations, Nevada Test Site. UCRL-53138, Lawrence Livermore National Laboratory, Livermore, California.

Oberlander, P.L. 1979. Development of a Quasi Three-Dimensional Groundwater Model for a Portion of the Nevada Test Site. Nv0-1253-14, Desert Research Institute, University of Nevada System, Las Vegas, Nevada.

Orkild, P.P. 1981. "Geology of Nevada Test Site." Paper presented at the Monterey Containment Symposium, Monterey, California, August 26-28, 1981. 
Pawloski, G.A. 1981. Water Contents of Samples from the NTS: Total, Free, and More Tightly Bonded. UCRL-53130, Lawrence Livermore National Laboratory, Livermore, California.

Pawloski, G.A. 1982. Results from Exploratory Drill Hole UE2ce, Northwest Yucca Flat, Nevada Test Site, near the Nash Event. UCID-19324, Lawrence Livermore National Laboratory, Livermore, California.

Quinlivan, W.D., and F.M. Byers, Jr. 1977. Chemical Data and Variation Diagrams of Igneous Rocks from the Timber Mountain-0asis Valley Caldera Complex, Southern Nevada. USGS-0FR-77-724, U.S. Geological Survey, Denver, Colorado.

Ramspott, L.D., and N.W. Howard. 1975. Average Properties of Nuclear Test Areas and Media at the USERDA Nevada Test Site. UCRL-51948, Lawrence Livermore National Laboratory, Livermore, California.

Rice, W.A. 1984. Preliminary Two-Dimensional Regional Hydrologic Model of the Nevada Test Site and Vicinity (Draft). SAND93-7466, PNL-4919, Pacific Northwest Laboratory, Richland, Washington.

Rogers, A.M., S.C. Harmsen, and W.J. Carr. 1981. Southern Great Basin Seismological Data Report for 1980, and Preliminary Analysis. USGS-OFR-831086 , U.S. Geological Survey, Denver, Colorado.

Rogers, A.M., S.C. Harmsen, and W.J. Carr. 1983. Southern Great Basin Seismological Data Report for 1981 and Preliminary Data Analysis. USGS-OFR83-669, U.S. Geological Survey, Denver, Colorado.

Rogers, A.M., and W.H.K. Lee. 1976. "Seismic Study of Earthquakes in the Lake Mead, Nevada-Arizona Regions." Bulletin of the Seismological Socjety of America 66:1657-1681.

Rogers, A.M., D.M. Perkins, and F.A. Mckeown. 1976. A Catalog of Seismicity within 400 Kilometers of the Nevada Test Site. USGS-0FR-76-832, U.S. Geological Survey, Denver, Colorado.

Rogers, A.M., G.M. Wuollet, and P.A. Covington, 1977. Seismicity of the Pahute Mesa Area, Nevada Test Site (8 October 1975 to 30 June 1976).

Nationai Technical Information Service, Springfield, Virginia.

Rush, F.E., W. Thordarson, and L. Bruckheimer. 1983. Geohydrologic and Dril1-Hole Data for Test We11 USW H-1. Adjacent to Nevada Test Site, Nye County, Nevada. USGS-0FR-83-141, U.S. Geological Survey, Denver, Colorado.

Russe11, C.E., J.W. Hess, and S.W. Tyler. 1987. "Hydrogeologic Investigations of Flow in Fractured Tuffs, Rainier Mesa, Nevada Test Site." Bulletin of the American Geophysical Union, pp. 43-50. 
Scott, R.B., and J. Bonk. 1984. Preliminary Geologic Map of Yucca Mountain with Geologic Sections, Nye County, Nevada. USGS-0FR-84-494, Scale $1: 12,000$, U.S. Geological Survey, Denver, Colorado.

Scott, R.B., and M. Castellanos. 1984. Stratigraphic and Structural Relations of Volcanic Rocks in Drill Holes USW GU-3 and USW G3, Yucca Mountain, Nye County, Nevada. USGS-0FR-84-491, U.S. Geological Survey, Denver, colorado.

Scott, R.B., R.W. Spengler, A.R. Lappin, and M.P. Chornack. 1982. "Structure and Intra-Cooling Unit Zonation in Welded Tuffs of the Unsaturated Zone, Yucca Mountain, Nevada, a Potential Nuclear Waste Repository, abs." EOS 63(18):330.

Scott, R.B., G.D. Bath, V.J. Flanigan, D.L. Hoover, J.G. Rosenbaum, and R.W. Spengier. 1984. Geological and Geophysical Evidence of Structures in Northwest-Trending Washes, Yucca Mountain, Southern Nevada, and The ir Possible Significance to a Nuclear Waste Repository in the Unsaturated Zone. USGS-OFR-84-567, U.S. Geologica] Survey, Denver, Colorado.

Sinnock, S. 1982. Geology of the Nevada Test Site and Nearby Areas, Southern Nevada. SAND82-2207, Sandia National Laboratories, A1buquerque, New Mexico.

Smith, C.F. 1970. Distribution of Radioactive Debris in the Project Handcar Nuclear Chimney. UCRL-50967, Lawrence Livermore National Laboratory, Livermore, California.

Snyder, D.B., and W.J. Carr. 1982. Preliminary Resuits of Gravity Investigations at Yucca Mountain and Vicinity, Southern Nye County, Nevada. USGSOFR-82-701, U.S. Geological Survey, Denver, Colorado.

Spengler, R.W., and J.G. Rosenbaum. 1980. Preliminary Interpretations of Geologic Results Obtained from Boreholes UE-25a-4, $-5,-6$, and -7 . Yucca Mountain Site. USGS-0FR-80-0929, U.S. Geological Survey, Denver, Colorado.

Spengier, R.W., F.M. Byers, Jr., and J.B. Warner. 1981. Stratigraphy and Structure of Volcanic Rocks in Drill Hole USW-GI, Yucca Mountain, Nye County, Nevada. USGS-OFR-82-1338, U.S. Geological Survey, Denver, Colorado.

Spengler, R.W., D.C. Muller, and R.B. Livermore. 1979. Preliminary Report on the Geology and Geophysics of Drill Hole UE25a-1, Yucca Mountain, Nevada Test Site. USGS-OFR-79-1244, U.S. Geological Survey, Denver, Colorado.

Squires, R.R., and R.L. Young. 1984. Flood Potential of Fortymile Wash and Its Principal Southwestern Tributaries, Nevada Test Site, Southern Nevada. Water Resources Investigations Report 83-4001, U.S. Geological Survey, Denver, Colorado. 
Stewart, J.H., and J.E. Carlson. 1978. Geologic Map of Nevada. Scale 1:500,000, U.S. Geological Survey and Nevada Bureau of Mines and Geology, Carson City, Nevada.

Stewart, J.H., W.J. Moore, and I. Zietz. 1977. "East-West Pattern of Cenozoic Igneous Rocks, Aeromagnetic Anomalies, and Mineral Deposits in Nevada and Utah." Geologic Society of America Bulletin 88:67-77.

Swadley, W.C. 1983. Map Showing Surficial Geology of the Lathrop Wells Quadrangle, Nye County, Nevada. MAP I-1361, U.S. Geologic Survey, Denver, Colorado.

Swadley, W.C., and D.L. Hoover. 1983. Geology of Faults Exposed in Trenches in Crater Flat, Nye County, Nevada. USGS-0FR-83-608, U.S. Geological Survey, Denver, Colorado.

Szabo, B.J., W.J. Carr, and W.C. Gottscha11. 1981. Uranium-Thorium Dating of Quaternary Carbonate Accumulations in the Nevada Test Site Region, Southern Nevada. USGS-OFR-81-119, U.S. Geological Survey, Denver, Colorado.

Thordarson, W. 1983. Geohydrologic Data and Test Results from We11 J-13, Nevada Test Site, Nye County, Nevada. Water Resources Investigations Report 83-4171, U.S. Geological Survey, Denver, Colorado.

Thordarson, W., F.E. Rush, R.W. Spengler, and S.J. Waddel1. 1984 . Geohydrologic and Drill-Hole Data for Test Well USW H-3, Yucca Mountain, Nye County, Nevada. USGS-0FR-84-149, U.S. Geologica? Survey, Denver, Colorado.

Thordarson, W., F.E. Rush, and S.J. Wadde11. 1985. Geohydrology of Test Well USW H-3, Yucca Mountain, Nye County, Nevada. Water Resources Invest $j-$ gations Report B4-4272, U.S. Geological Survey, Denver, Colorado.

Townsend, D.R., M.J. Baldwin, R.D. Carroll, W.L. Ellis, and J.E. Magner. 1982. Geoloqic, Geophysical, and In Situ Stress Investigation in the Vicinity of the Dining Car Chimney, Dining Car/Hrbla Gold Drifts, Nevada Test Site. USGS-0FR-82-137, U.S. Geological Survey, Denver, Colorado.

Tschanz, C.M., and E.H. Pampeyan. 1970. Geologic Map of Lincoln County, Nevada. Bulletin 73, Nevada Bureau of Mines, Carson City, Nevada.

Tyler, S.W. 1987. Review of Soil Moisture Flux Studies at the Nevada Test Site, Nye County, Nevada. DOE/NV/10384-17, U.S. Department of Energy, Las Vegas, Nevada.

Tyler, S.W., W.A. McKay, J.W. Hess, R.L. Jacobsen, and K.C. Taylor. 1986. Effects of Surface Collapse Structures on Infiltration and Moisture Redistribution. DOE/NV/10284-04, U.S. Department of Energy, Las Vegas, Nevada. 
U.S. Department of Energy (DOE). 1986. Yucca Mountain Site, Nevada Research and Development Area, Nevada. DOE/RW-0073, U.S. Department of Energy, Washington, D.C.

U.S. Energy Research and Development Administration (ERDA). 1977. Nevada Test Site, Nye County, Nevada, Final Environmental Impact Statement. ERDA1551, U.S. Energy Research and Development Administration, Washington, D.C.

U.S. Geological Survey (USGS). 1978. U.S. Geological Survey Investigations in Connection with the Dining Car Event, U12e. 18 Tunnel, Rainier Mesa, Nevada Test Site. USGS-474-246, U.S. Geological Survey, Denver, Colorado.

U.S. Geological Survey (USGS). 1983a. Geohydrologic Data and Test Results from Well J-13. Nevada Test Site, Nye County, Nevada. Water Resources Investigations Report 83-4171, U.S. Geological Survey, Denver, Colorado.

U.S. Geological Survey (USGS). 1983b. Preliminary Determination of Epicenters, National Earthquake Information Service, Monthly Listing. Prepared by National Oceanic and Atmospheric Administration, Washington, D.C.

U.S. Geological Survey (USGS). 1984. A Summary of Geologic Studies Through January 1, 1983, of a Potential High-Level Radioactive Waste Repository Site at Yucca Mountain, Southern Nye County, Nevada. USGS-0FR-84-792, U.S. Geological Survey. Denver, Colorado.

Vetter, U.R., and A.S. Ryall. 1983. "Systematic Change of Focal Mechanism with Depth in the Western Great Basin." Journal of Geophysical Research B88(10):8237-8250.

Wadde11, R.K., Jr. 1982. Two-Dimensional, Steady-State Model of GroundWater Flow, Nevada Test Site and Vicinity, Nevada-Cal ifornia. Water Resources Investigations Report 82-4085, U.S. Geologica? Survey, Denver, Colorado.

Wadde ll, R.K., J.H. Robison, and R.K. Blankennagel. 1984. Hydrology of Yucca Mountain and Vicinity, Nevada-Cal ifornia--Investigative Results Through Mid-1983. Water Resources Investigations Report 84-4267, U.S. Geological Survey, Denver, Colorado.

Wagoner, J.L., and L.D. Ramspott. 1981. Results of Exploratory Dri1l Hole UE7nS, East-Central Yucca Flat, Nevada Test Site, UCID-18979, Lawrence Livermore National Laboratory, Livermore, California.

Wang, J.S.Y., and T.N. Narasimhan. 1985. Hydrologic Mechanisms Governing Fluid Flow in Partially Saturated. Fractured, Porous Tuff at Yucca Mountain. SAND84-7202, Sandia National Laboratories, Albuquerque, New Mexico.

Weeks, E.P., and W.E. Wilson. 1984. Prel iminary Evaluation of Hydrologic Properties of Cores of Unsaturated Tuff, Test Well USW H-1, Yucca Mountain. Nevada. Water Resources Investigations Report 84-4193, U.S. Geological Survey, Denver, CoTorado. 
Whitfield, M.S., Jr., W. Thordarson, and E.P. Eshom. 1984. Geohydraulic and Dri]1-Hole Data for Test Wel1 USW H-4, Yucca Mountain, Nye County. Nevada. USGS-OFR-84-449, U.S. Geological Survey, Denver, Colorado.

Williams, W.P., W.L. Emerick, R.E. Davis, and R.P. Snyder. 1963. U.S. Ge0logical Survey Investigations in Yucca Flat, NTS; Part $C$. The Underground Test Media of Yucca Flat. USGS Tech. Letter NTS 45-C, U.S. Geological Survey, Washington, D.C.

Winograd, 1.J., and G.C. Doty. 1980. Paleohydrology of the Southern Great Basin, with Special Reference to Water Table Fluctuations Beneath the Nevada Test Site During the Late(?) Pleistocene. USGS-OFR-80-127, U.S. Geological Survey, Denver, Colorado.

Winograd, I.J. and F.J. Pearson, Jr. 1976. "Major Carbon 14 Anomaly in Regional Carbonate Aquifer: Possible Evidence for Megascale Channeling, South Central Great Basin." Water Resources Research 12(6).

Winograd, I.J., and W. Thordarson. 1975a. Hydrogeoloqic and Hydrochemical Framework. South-Central Great Basin, Nevada-California, with Special Reference to the Nevada Test Site. Professional Paper 712-C, U.S. Geological Survey, Washington, D.C.

Winograd, I.J., and W. Thordarson. 1975b. Structural Control of GroundWater Movement in Miogeosynclinal Rocks of South-Central Nevada. Memoir 110, Geological Society of America, Denver, Colorado.

Winograd, I.J., W. Thordarson, and R.A. Young. 1971. Hydrology of the Nevada Test Site and Vicinity, Southeastern Nevada. Open-File Report, U.S. Geologica] Survey, Denver, Colorado.

Zietz, I., F.P. GiTbert, and J.R. Kirby. 1978. Aeromagnetic Map of Nevada: Color-Coded Intensities. Geophysical Investigations Map GP-922, Scale $1: 100,000$, U.S. Geological Survey, Denver, Colorado.

Zoback, M.L., R.E. Anderson, and G.A. Thompson. 1981. "Cenozoic Evolution of the State of Stress and Style of Tectonism of the Basin and Range Province of the United States." Philosophical Iransactions of the Royal Society of London A300:407-434.

Zoback, M.L., and G.A. Thompson. 1978. "Basin and Range Rifting in Northern Nevada: Clues from a Mid-Miocene Rift and Its Subsequent Offsets." Geology 6 $2: 111-116$.

Zoback, M.L., and M.D. Zoback. 1980. "Faulting Patterns in North-Central Nevada and Strength of Crust." Journal of Geophysical Research 85:61136156 . 


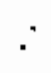

: 
APPENDIX A

ANNOTATED BIBLIOGRAPHY 
APPENDIX A

\section{ANNOTATED BIBLIOGRAPHY}

This annotated bibliography contains brief summaries of the documents reviewed for this report. There was no attempt to judge the validity, quality, or importance of the documents or the data contained therein. The summaries generally are edited versions of the documents' abstracts; a few are newly written based on the published abstracts and the reports themselves. The summaries are organized into the following categories:
A. Geology, Hydrology, and Hydrogeology of the NTS
B. Distribution and Transport of Radionuclides at the NTS
C. Sorption and Leaching Studies
D. Modeling Studies

\section{A. Geology, Hydrology, and Hydrogeology of the NTS}

Anderson, L.A. 1984. Rock Property Measurements on Large-Volume Core Samples from Yucca Mountain USW GU-3\G-3 and USW G-4 Boreholes, Nevada Test Site, Nevada. USGS-0FR-84-552, U.S. Geologica7 Survey, Denver, Colorado.

Core samples from the boreholes were obtained for the purpose of making rock property measurements, as part of the NNWSI project. Samples representative of the major lithologic variations observed within the principal stratigraphic units were selected at the drill site. Upon removal from the borehole, the cores were washed free of dritling mud, labeled as to depth and vertical attitude, wrapped in aluminum foil, and coated with beeswax in an effort to minimize the loss of natural pore water during the period prior to rock property analysis. Samples were then measured for electrical resistivity, induced polarization, porosity, bulk and grain density, and compressional sonic velocity.

Balch, A.H., M.W. Lee, and D.C. Muller. 1980. A Vertical Seismic Profiling Experiment to Determine Depth and Dip of the Paleozoic Surface at Drill Hole Ulobd, Nevada Test Site, Nevada. USGS-OFR-80-847, U.S. Geological Survey, Denver, Colorado.

The purposes of the experiment were 1) to obtain seismic reflections from the Paleozoic surface beneath the Quaternary and Tertiary deposits of Yucca Flat and 2) to compare different sources used to generate seismic energy for vertical seismic profiles. Five profiles were made, two using surface sources and three using downhole sources. The seismic signal was detected with a downhole clamping geophone. The reflection from the Paleozoic surface was evident on ail five profiles, with no source showing an 
advantage over the others. Velocity filtering was shown to be a viable method for obtaining reflections from the Paleozoic surface beneath Yucca Flat.

Baldwin, M.J., and C.E. Jahren. 1982. Magnetic Properties of Drill Core and Surface Samples from the Calico Hills Area, Nye County, Nevada. USGS-OFR-82-536, U.S. Geological Survey, Denver, Colorado.

The interpretation of the aeromagnetic survey of the $\mathrm{Calico} \mathrm{Hills}$ area of the NTS required the determination of magnetic properties of rocks exposed in the region. Eighty-two samples, representing a variety of units found at the surface, showed that most rocks in the Calico Hills, other than parts of the Eleana Formation, are relatively nonmagnetic. The magnetic vector of the Eleana Formation at the surface was found to point northward and downward.

Barnes, M.G., E.B. Ekren, C.L. Rogers, and Hedlund. Mercury Quadrangle, Nevada.

This document summaries regional, structural and geological history of the Mercury Quadrangle.

Barr, G.E. 1985. Reduction of the Well Test Data for Test Well USWH-I, Adjacent to NTS, Nye County, Nevada. SAND84-0637, Sandia National Laboratories, Albuquerque, New Mexico.

The purpose of this report is to reduce the test data from USW $\mathrm{H}-\mathrm{l}$, which was drilled by USGS. The analyses were done to suppiy the performance assessment with hydraulic parameters for use in studies. After the initial analyses for this report were complete, F.E. Rush and others published the USGS analyses of hydraulic conductivity for the well. This report provides an independent confirmation of hydraulic conductivity estimates for the well, as well as a listing of storativity estimates.

Bentley, C.B. 1984. Geohydrologic Data for Test We 1] USW G-4, Yucca Mountain Area, Nye County, Nevada. USGS-0FR-84-063, U.S. Geological Survey, Denver, Colorado.

This report presents data on drilling operations, lithology, borehole geophysics, hydrologic monitoring, core analyses, water chemistry, pumping tests, and packer-injection tests for test well USW G-4. The well is one of a series of test wells drilled in and near the southwestern part of the NTS. These test wells are part of the effort to identify suitable sites for underground storage of high-level radioactive wastes.

Bentley, C.B., J.H. Robison, and R.W. Spengler. 1983. Geohydrologic Data for Test Well USW H-5, Yucca Mountain Area, Nye County, Nevada.

USGS-0FR-83-853, U.S. Geological Survey, Denver, Colorado.

This report presents data collected to determine the hydraulic characteristics of rocks penetrated by test well USW H-5. The well is one of a series drilled in and near the southwestern part of the NTS. These 
investigations are part of the effort to identify suitable sites for underground storage of high-level radioactive wastes. Data on drilling operations, lithology, borehole geophysics, hydrologic monitoring, pumping, swabbing, and injection tests for the well are contained in this report.

Bish, D.L. 1981. Detalled Mineralogical Characterization of the Bullfrog and Tram Members in USW-G1, with Emphasis on Clay Mineralogy. LA-9021-MS, Los Alamos National Laboratory, Los Alamos, New Mexico.

The detailed mineralogy of the Bullfrog and Tram Members of the Crater Flat Tuff as seen from drill hole USW-Gl has been examined, primarily to characterize fully the amounts and types of clay minerals in the tuffs and the possible effects that clay minerals have on rock properties.

Bish, D.L., D.T. Vaniman, F.M. Byers, Jr., and D.E. Broxton. 1982. Summary of the Mineralogy-Petrology of Tuffs of Yucca Mountain and the SecondaryPhase Thermal Stability in Tuffs. LA-9321-MS, Los Alamos National Laboratory, Los Alamos, New Mexico.

This report summarizes our knowledge of the mineralogy and petrology of the tuffs of Yucca Mountain related to geologic studies for the NNWSI. It describes the currently known range of lateral variability of the tuff units and the variation in mineralogy and petrology from unit to unit as determined by studies of cores obtained from exploratory drilling. The distribution of secondary phases, including clays, zeolites, and silica phases, is also documented, and the current state of knowledge concerning the effects of temperature on these secondary phases and how that would affect a repository are reviewed.

Brethauer, G.E. 1979. Preliminary Investiqation of Physical-Properties Data from Pahute Mesa, Nevada Test Site, Using the GRASP Storage and Retrieval System. USGS-474-307, U.S. Geological Survey, Denver, Colorado.

The GRASP (Geologic Retrieval and Synops is Program) system was used to select and calculate statistical parameters of physical-property data obtained from Pahute Mesa, NTS, Nevada. Preliminary analysis of these data indicates that physical-properties values are not homogeneous throughout Pahute Mesa and do not vary linearly with direction or depth.

Brethauer, G.E., J.E. Magner, and D.R. Miller. 1980. Statistical Evaluation of Physical Properties in Area 12, Nevada Test Site, Using the USGS/DNA Storage and Retrieval System. USGS-0FR-474-309, U.S. Geologica] Survey, Denver, Colorado.

The USGS/DNA Physical-Properties Storage and Retrieval System was used to generate tables displaying the basic statistics of physical-properties data sets sorted according to geologic identification and tunnel complex in the Rainier and Aqueduct mesas. An approximating procedure was developed to statistically evaluate the significance of geologic identifier versus 
physical-property average value. Results of this procedure did not indicate any conclusive consistent relation between geologic identifier and physicalproperties average value.

Brethaver, G.E., D.C. Muller, and J.E. Kibler. 1980. Preliminary Analys is of Physical-Properties Data Characteristics of Tunnel Beds 3 and 4 in a Part of Areas 4 and 7, Nevada Test Site. USGS-474-310, U.S. Geological Survey, Denver, Colorado.

Physical-property data for two 1 ithologic units within the tunnel beds were analyzed using the GRASP system. The properties show good uniformity and can be used to predict physical properties by extrapolation and interpolation for new sites, thus effecting substantial savings by reducing the amount of geologic and geophysical data that need be collected.

Broxton, D., D. Vaniman, F. Caporuscio, B. Arney, and G. Heiken. 1982. Detailed Petrographic Descriptions and Microprobe Data for Drill Holes USW-G2 and UE25b-1H, Yucca Mountain, Nevada. LA-9324-MS, Los Alamos National

Laboratory, Los Alamos, New Mexico.

These drill holes at Yucca Mountain penetrate a thick sequence of volcanic rocks consisting of voluminous ash-flow tuffs, intercalated with thin bedded tuffs and minor lavas. This report provides detailed petrologic descriptions. Microprobe analyses of feldspars and mafic phenocrysts as well as secondary feldspars are tabulated for these drill holes.

Byers, F.M., Jr., and W.L. Hawkins. 1981. Geology of Drill Hole Vel8t and Area 18, Timber Mountain Caldera Moat, NTS. USGS-474-312, U.S. Geologiçal Survey, Denver, Colorado.

Drill hole UEl8t, located in the northeastern part of the Timber Mountain caldera moat (Area 18), Nye County, Nevada, was sited to obtain chemical and physical data of the caldera-fill deposits and to extend knowledge of the geologic and hydrologic environment of the NTS. The full suite of geophysical logs (caliper, density, resistivity, spontaneous potential, velocity, and neutron) from UEl8t were interpreted and compared with physical properties measured on the core. Cross-piot techniques were used to obtain additional properties of ash-flow tuffs below the water table. The log properties and cross plots indicate the quartzo-feldspathic tuffs of the Rainier Mesa Member have physical properties approaching those of granite. Correlation of $10 \mathrm{~g}$ properties indicates that bedded tuffs above the Rainier Mesa Member and below the water table have very low permeability. Recommendations are made for locating additional emplacement sites.

Carr, W.J. 1982. Volcano-Tectonic History of Crater Flat, Southwestern Nevada, as Suggested by New Evidence from Dri11 Hole USW-VH-1, and Vicinity. USGS-0FR-82-457, U.S. Geological Survey, Denver, Colorado.

New evidence for a possible resurgent dome in the caldera related to eruption of the Bullfrog Member of the Crater Flat Tuff has been provided by recent drilling of a $2,499-\mathrm{ft}(762-\mathrm{m})$ hole in central Crater Flat. Although 
no new volcanic units were penetrated by the drill hole, a positive aeromagnetic anomaly in the vicinity of the drill hole appears to result in part from the unusually thick, densely welded tuff of the Bullfrog. Major units penetrated include alluvium, basalt of Crater Flat, Tiva Canyon, and Topopah Spring Members of the Paintbrush Tuff, and Prow Pass and Bullfrog Members of the Crater Flat Tuff.

Carr, W.J., G.D Bath, D.L. Healey, and R.M. Hazelwood. 1975. Geology of Northern Frenchman Flat, NTS. USGS-474-216, U.S. Geological Survey, Denver, Colorado.

A special geologic and geophysical study of the northern part of Frenchman Flat yielded considerable detailed information on the stratigraphy and structure of that area. In general, the rocks are similar to those of Yucca Fiat, except that the rocks of Frenchman Flat include relatively highdensity and high-velocity alluvium at depths of 500-1,000 feet (152-304 m), and a greater proportion of dense tuff units, mainly welded tuff. Basalt lava flows are intercalated in the high-velocity alluvium. The Thirsty Canyon Tuff, an important stratigraphic marker, has been identified for the first time in this part of the NTS.

Carr, W.J., C.H. Miller, and H.W. Dodge, Jr. 1975. Geology, Physical Properties, and Surface Effects at Discus Thrower Site, Yucca Flat, Nevada Test Site. USGS-0FR-75-410, U.S. Geological Survey, Denver, Colorado.

Geologic studies in connection with Project Discus Thrower have furnished detailed stratigraphic and structural information about northwestern Yucca Flat. The Paleozoic rocks consist of a lower carbonate sequence, argillite of the Eleana Formation, and an upper carbonate sequence.

Carrol1, R.D., and J.E. Kibler. 19B3. Sourcebook of Locations of Geophysical Surveys in Tunnels and Horizontal Holes, Including Results of Seismic Refraction Surveys, Rainier Mesa, Aqueduct Mesa, and Area 16, Nevada Test Site. USGS-0FR-83-399, U.S. Geological Survey, Denver, Colorado.

Starting in 1967 and continuing at least to 1982, extensive measurements of shear- and compressional-wave velocities were made in five tunnel complexes in Rainier and Aqueduct mesas and in one tunnel complex in Shoshone Mountain. The results of these surveys to 1980 are compiled in this report. A] so beginning in 1967, extensive horizontal drilling was conducted in connection with geologic exploration in these tunnel complexes for sites for nuclear weapons tests. Seismic and electrical surveys were conducted in the majority of these holes. The types and locations of these tunnel and borehole surveys are indexed in this report.

Carroll, P.I., F.A. Caporuscio, and D.L. Bish. 1981. Further Description of the Petrology of the Topopah Spring Member of the Paintbrush Tuff in Drill Holes UE25A-l and USW-G1 and of the Lithic-Rich Tuff in USW-G1, Yucca Mountain, Nevada. LA-9000-MS, Los Alamos National Laboratory, Los Alamos, New Mexico. 
This report augments earlier petrologic characterization of the Topopah Spring Member of the Paintbrush Tuff and the lithic-rich tuff, two Tertiary volcanic units that occur in cores from drill holes UE251-1 and USW-G1 at Yucca Mountain. Recently these units have been suggested as possibly suitable for the permanent storage of high-level radioactive waste.

Case, C.M. 1977. Constitutive Relations for Flow of Water in the Unsaturated Zone. NVO-1253-1I, Desert Research Institute, University of Nevada System, Las Vegas, Nevada.

The study of flow of water and the concomitant transport of radionuclides in the unsaturated zones of the NTS has necessitated a detailed and thorough review of fundamental unsaturated flow theory. In the course of this review, it became evident that additional formalism to describe the basic quantities and state the fundamental concepts of unsaturated flow was required. This report introduces the terminology and concepts of a more precisely formulated theory of unsaturated flow than appeared in the literature prior to 1977. The results given are basic and add to the precision of the formulation of the equations for flow in the unsaturated zone.

Case, C.M., D.L. Ghiglieri, and K. Fallon, 1979. Tables of the Leaky Aquifer Well Function. DRI No. 45016, Water Resources Center, Desert Research Institute, University of Nevada System, Las Vegas, Nevada.

These tables of the leaky aquifer well function have been calculated using an adaptation of an expansion in terms of exponential integra]s. These tables are calculated to a higher precision and to extended ranges of the usual lumped-parameter independent variables than older tables. The series representation used in the computations converges absolutely and appears not to have been noted in the literature previously.

Case, C., M. Kautsky, P. Kear1, R. Goldfarb, S. Leatham, and L. Metcalf. 1983. Unsaturated Flow Properties Data Catalog, Volume 1. DOE/NV/10162-12, Publication 45033, Water Resources Center, Desert Research Institute, University of Nevada System, Las Vegas, Nevada.

This publication catalogs data on unsaturated flow properties of soils, such as matric potential as a function of degree of saturation or volumetric saturation; unsaturated hydraulic conductivity as a function of matric potential or saturation; dispersivity as a function of saturation or matric potential; and so on. The catalog is arranged by soil type and by parameter within a given soil type.

The data were compiled from literature published through about 1982 and, for the most part, data reported in the 1976 catalog of Mualem are excluded. A literature citation is given for each set of data. The catalog uses published experimental results only and expresses parameter quantities in a consistent set of units. Parameters are plotted as graphs, all with the same scale and physical size, so that direct visual comparison of the results of various experiments is possible for the first time. The data points used to plot the graphs are given with the graphs. In addition, for ease of use in 
modeling programs, a least-squares polynomial fit is shown on the graph. The points used are shown for all cases to advise the reader of the "goodness of fit." Where available, values for porosity and saturated hydraulic conductivity are given in as much detail as possible and are summarized reiative to soil type and experimental procedure.

Case, C., J. Davis, R. French, and S. Raker. 1984. Site Characterization in Connection with the Low-Level Defense Waste Management Site in Area 5 of the Nevada Test Site, Nye County, Nevada--Final Report. DOE/NV/10162-13, Water Resources Center, Desert Research Institute, University of Nevada System, Las Vegas, Nevada.

This site characterization report for the Defense Low-Level Waste Management Site in Area 5 of the NTS reports DRI activities for FY $1980-$ FY 1984. The topics studied include geology, hydrology, unsaturated flow, soil and soil water chemistry, flood hazard, and economics-demographics. The site characterization effort focussed on a number of areas, including

- Geological and hydrological limitations to deeper disposal of radioactive waste.

- Potential for tectonic, seismic or volcanic activity (extent and frequency with which these processes significantly affect the ability of the disposal operation to meet performance objectives).

- The possibility of ground water intrusion into the waste zone, and its significance.

Claassen, H.C. 1983. Sources and Mechanisms of Recharge for Ground Water in the West-Central Amargosa Desert, Nevada--A Geochemical Interpretation. USGS-OFR-83-542, U.S. Geological Survey, Denver, Colorado.

Ground water in the west-central Amargosa Desert, Nevada, was recharged primarily by overland flow of snowmelt in or near the present-day stream channels, rather than by subsurface flow from highland recharge areas to the north. Geochemical arguments, including reaction mechanisms, are used to support these findings. Carbon-, hydrogen-, and oxygen-isotope data show that much of the recharge in the area occurred during late Wisconsin time. The absence of ground water recharged before the late Pleistocene is considered to indicate that either climatic conditions were unfavorable for recharge or that ground-water velocities were such that they transported this earlier recharge away.

Claassen, H.C., and E.H. Cordes. 1975. "Two-Well Recirculating Tracer Test in Fractured Carbonate Rock, Nevada." Hydrological Sciences Bulletin 20(3).

A two-well recirculating tracer test in a highly conductive fractured carbonate aquifer in southern Nevada yielded values of $2.9 \mathrm{ft}(0.9 \mathrm{~m})$ for the product of porosity and thickness and $50 \mathrm{ft}(15 \mathrm{~m})$ for the dispersivity of the aquifer. These data were combined with hydraulic-test and hydraulicgradient data to provide estimates of average ground-water velocity in the 
aquifer of 0.47 to $11 \mathrm{ft} / \mathrm{d}(0.14$ to $3.3 \mathrm{~m} / \mathrm{d})$. A method for analys is of nondispersed flow to observation wells in the flow-net is also presented.

Cornwa11, H.R. 1972. Geology and Mineral Deposits of Southern Nye County, Nevada. Bulletin 77, Mackay School of Mines, University of Nevada, Reno, Nevada.

This bulletin is part of a series of county reports whose purposes are to aid in the exploration and development of each county's mineral and water resources, to facilitate further regional and local geologic studies, and to supply geologic data to be compiled in a projected state geologic map.

Craig, R.W., and K.A. Johnson. 1984. Geohydrologic Data for Test Wel? UE-25p\#1, Yucca Mountain Area, Nye County, Nevada. USGS-0FR-84-450, U.S. Geological Survey, Denver, Colorado.

This report describes the drilling operations, lithology, availability of borehole geophysical logs, water levels, water chemistry, pumping tests, borehole-flow survey, and packer-injection tests for test weil UE-25p\#1. The well was drilled to a total depth of $5,920 \mathrm{ft}(1,805 \mathrm{~m})$. To a depth of $4,080 \mathrm{ft}(1,244 \mathrm{~m})$, the rocks are predominantly ash-flow tuffs of Tertiary age. From 4,080 to $5,920 \mathrm{ft}(1,244$ to $1,805 \mathrm{~m})$, the rock is dolomite of Paleozoic age.

Craig, R.W., R.L. Reed, and R.W. Spengler. 1983. Geohydrologic Data for Test Well USH H-6 Yucca Mounta in Area, Nye County, Nevada. USGS-0FR-83-856, U.S. Geological Survey, Denver, Colorado.

This report describes the drilling operations, lithology, availability of borehole geophysical logs, water levels, future availability of core analyses, water chemistry, pumping tests, and packer-injection tests for test well USW H-6.

Daily, W., W. Lin, and T. Buscheck. 1985. Hydrological Properties of Topopah Spring Tuff - Laboratory Measurements. UCRL-94363, Lawrence Livermore National Laboratory, Livermore, California.

This report documents a study of the transport of water in tuff from the Topopah Spring welded unit under conditions expected in the near-field environment of a high-level nuclear-waste container. A naturaliy fractured sample of Topopah Spring tuff was studied using, as a pore fluid, natura? ground water recovered from a well in which the principal producing horizon is the Topopah Spring Member. Confining pressure, sample temperature, and pore pressure were held at values that simulated the expected in situ nearfield conditions shortly after emplacement of the container.

Daniels, J.J., J.H. Scott, and J.T. Hagstrum. 1981. Interpretation of Geophysical Well-Log Measurements in Drill Holes UE25a-4, $-5,-6$, and -7 , Yucca Mountain, Nevada Test Site. USGS-0FR-81-615, U.S. Geological Survey, Denver, Colorado. 
Exploratory holes were drilled at the NTS to determine the suitability of pyroclastic deposits as storage sites for radioactive waste. Studies have been conducted to investigate the stratigraphy, structure, mineralogy, petrology, and physical properties of the tuff units encountered in the drill holes.

Daniels, W.R., et a]. 1982. Summary Report on the Geochemistry of Yucca Mountain and Environs. LA-9328-MS, Los Alamos National Laboratory, Los Alamos, New Mexico.

This report describes technical efforts conducted from FY 1977 untif March 1982 to resolve geochemistry issues pertinent to siting a nuclear-waste repository in tuff at the NTS. Tuff provides the first natural barrier to the migration of waste elements from a repository; therefore, the properties and setting of tuff were investigated, with particular emphasis on retardation processes. This report addresses sorption by tuff, the physical and chemical makeup of tuff, diffusion processes, tuff/ground-water chemistry, waste-element chemistry under expected repository conditions, transport processes involved in porous and fracture flow, and geochemical and transport modeling.

Davis, J. 1983. Geological Reconnaissance and Chronologic Studies. DOE/NV/10162-9, Desert Research Institute, University of Nevada System, Las Vegas, Nevada.

Geologic reconnaissance on and around the NTS was undertaken to identify specific evidence of depositional, erosional, and hydrologic events, as well as to develop an understanding of the timing of these events.

Ege, J.R., and M.J. Cunningham. 1976. Geology of the U12n.10 UG-1 Horizontal Drill Hole, Rainier Mesa, Area 12, NTS, Nevada. USGS-474-218, U.S. Geological Survey, Denver, Colorado.

This report describes a drill hole that starts in tunnel-bed subunit $4 \mathrm{~F}$; passes down the stratigraphic section through subunits $4 E, 4 C D, 4 A B, 3 D, 3 B C$; penetrates the northwest 1 imb of a northeast-trending syncline; and terminates in subunit $3 \mathrm{~A}$, all of Tertiary age. A fault observed in the core at $1,234 \mathrm{ft}(376.4 \mathrm{~m})$ has been correlated with a lineation mapped on the surface of Rainier Mesa. The distance between the end of the boring and the underJying pre-Tertiary surface is about $290 \mathrm{ft}(88.4 \mathrm{~m})$. A fault cuts the preTertiary surface and is downthrown $98-200 \mathrm{ft}(30-61 \mathrm{~m})$ to the east. The trace of this fault would project vertically to $1,529 \mathrm{ft}(466.3 \mathrm{~m})$ in the drill hole; however, no evidence of this fault is seen in the boring, and therefore it is assumed to be pre-Tertiary in age. No serious construction or support problems are anticipated for any drift mined along the drill-hole a] inement. The rock is generally competent, and there are no zones of extensive argillization.

Ege, J.R., H.W. Dodge, Jr., D.R. Miller, and J.E. Magner. 1976. Determination of In Situ Stress in U12t.02 Sri Alcove, Aqueduct Mesa, NTS.

USGS-474-236, U.S. Geological Survey, Denver, Colorado. 
Stress-relief borehole-deformation measurements using the U.S. Bureau of Mines overcoring technique were made in the U12t.02 drift at a depth of $\mathrm{I}, 180 \mathrm{ft}(359.7 \mathrm{~m})$ below the surface of Aqueduct Mesa. The measurements were made in three noncoplanar boreholes drilled in low-modulus, low-density volcanic rocks and were used to calculate the three-dimensional stress field. All stresses were found to be compressive. The calculated vertical-stress component of 65.6 bars is consistent with the estimated vertical stress attributed to overburden. The maximum principal stress of 65.8 bars trends $\mathrm{N} 74 \mathrm{E}$ and is $4^{\circ}$ off the vertical. The minimum stress of 26.0 bars trends $\mathrm{S} 62 \mathrm{E}$ and is $3^{\circ}$ below horizontal. These trends are similar to other stress measurements made at the NTS.

Ege, J.R., R.D. Carroli, J.E. Magner, and D.R. Cunningham. 1980. U.S.G.S. Investigations in the U12n.03 Orift, Rainier Mesa, Area 12, NTS. USGS-OFR-80-1074, U.S. Geological Survey, Denver, Colorado.

The report describes seismic velocity, electrical resistivity, and geologic surveys in the U12 $\mathrm{n} .03 \mathrm{drift}$ conducted to provide information needed for site evaluation. Sejsmic compressional wave velocities were found to range from 2,088 to $2,667 \mathrm{~m} / \mathrm{s}$ and electrical resistivities to range from 6.0 to 48 ohmmeters beneath a thin surface layer generally characterized by higher resistivities. Resistivity measurements indicated that sections of rock that may potentially be unstable for tunnel construction as a result of the presence of clay may be defined by this technique.

Ege, J.R., W. Danilchik, and C.T. Feazel. 1980. Geoloqy of the U12n.02 Drift, and Postshot Observations, Rainier Mesa, Area 12, NTS. USGS-474-229, U.S. Geological Survey, Denver, Colorado.

Mining of the U12n.02 drift for the Midi Mist event started on Dec. 31 , 1965 , and was completed on Dec. 30, 1966. The drift was mined along a bearing of $S 65 \mathrm{~W}$ at an altitude of $6,069 \mathrm{ft}(1,850.2 \mathrm{~m})$ to a total length of $2,109 \mathrm{ft}(643 \mathrm{~m})$. The drift lies in tunnel bed 4 and penetrates stratigraphically up the section through subunits $4 \mathrm{ab}, 4 \mathrm{~cd}, 4 \mathrm{e}, 4 \mathrm{f}, 4 \mathrm{~g}, 4 \mathrm{~h}$, and $4 \mathrm{j}$, all of Tertiary age. Two faults mapped at the surface of the mesa were identified as having cut the complex at drift level. No engineering construction or support problems greater than minor rock slabbing, gravelly ground, or water inflow along fractures were encountered. Visual inspection showed that shot-induced effects in the rock medium at drift level extended for $780 \mathrm{ft}(237.7 \mathrm{~m})$ from the working point and occurred in the form of fractures and small shear displacements along bedding planes.

Ekren, E.B., R.E. Anderson, C.L. Rogers, and D.C. Noble. 1971. Geology of Northern Nell is Air Force Base Bombing and Gunnery Range, Nye County, Nevada. Professional Paper 651, U.S. Geological Survey, Denver, Colorado.

The area of study, covering about 2,400 square miles $\left(6,240 \mathrm{~km}^{2}\right)$ in Nye County, southwestern Nevada, lies east of Goldfield. Elevations range from $4,700 \mathrm{ft}(1,429 \mathrm{~m})$ in the westernmost alluvial valley to more than $8,900 \mathrm{ft}$ $(2,706 \mathrm{~m})$ in the northeastern part of the area. Igneous rocks of Tertiary 
age form at least $90 \%$ of the outcrops. The remainder consist of sedimentary rocks of late Precambrian and Paleozoic age and a single small horst of crystalline basement.

Ellis, W.L. 1983. Hydraulic-Fracturing Measurements in Two Boreholes near the Spent Fue? Test-Climax, Climax Stock, NTS. USGS-0FR-83-406, U.S. Geological Survey, Denver, Colorado.

Hydraulic-fracturing measurements are used to infer the magnitude of the least principal stress in the vicinity of the Spent Fuel Test-Climax, located in the Climax stock at the NTS. The measurements, made at various depths in two exploratory boreholes, suggest that the local stress field is not uniform. Estimates of the least principal stress magnitude vary over distances of a few tens of meters, with the smaller values averaging $2.9 \mathrm{MPa}$ and the larger values averaging $5.5 \mathrm{MPa}$. The smaller values are in agreement with the minimum-stress magnitude of $2.8 \mathrm{MPa}$ determined in a nearby mass, and the influence of nearby faults may account for the apparent variation in minimum-stress magnitude indicated by the hydrofracture data.

Ellis, W.L., and J.R. Ege. 1975, Determination of In Situ Stress in U12g Tunnel, Rainier Mesa. Nevada Test Site, Nevada. USGS-474-219, U.S. Geological Survey, Denver, Colorado.

Measurements of stress-relief borehole deformation using the U.S. Bureau of Mines overcore technique were made at a depth of $1,450 \mathrm{ft}(442 \mathrm{~m})$ below Rainier Mesa, NTS. The measurements, made in three noncoplaner boreholes drilled in low-modulus, low-density volcanic rocks, were used to calculate the three-dimensional stress field. All stresses were found to be compressive. The calculated vertical stress component of 67 bars is consistent with the estimated vertical stress attributed to overburden. The maximum principal stress ( 85 bars) trends $N 21$ E and the minimum stress (26 bars) trends $\mathrm{N} 68 \mathrm{~W}$; both are nearly horizontal. Other syntheses of geologic and geophysical data indicate a similar orientation of the maximum and minimum horizontal stresses on a regional scale.

Ellis, W.L., and J.D. Kibler. 1983. Explosion-Induced Stress Changes Estimated from Vibrating-Wire Stressmeter Measurements near the Mighty Epic Event, NTS, USGS-OFR-83-642, U.S. Geological Survey, Denver, Colorado.

Increases in explosion-induced compressive stress near an underground nuclear explosion are believed to contribute significantiy to the containment of high-pressure gases within the explosion-produced cavity. These induced compressive stresses have been predicted by computer calculations, but have never been adequately confirmed by field measurements, owing primarily to the unique difficulties of obtaining such field data. Vibrating-wire stressmeter measurements made near the Mighty Epic nuclear detonation, however, qualitatively indicate that within $492 \mathrm{ft}(150 \mathrm{~m})$ of the working point, permanent compressive stress increases of several megapascals were present 15 weeks after the event. Additionally, stress-change magnitudes interpreted from the stressmeter data between the 246 and $853 \mathrm{ft}(75$ and $260 \mathrm{~m})$ from the working point compare favorably with calculated predictions of the stress changes 
shortly after detonation of the event. The measurements and calculations differ, however, with regard to the pattern of stress change radial and transverse to the explosion source. For the range of the field measurements from the working point, computer models predict that the largest compressivestress increase will be radial to the explosion source; the field data indicate that the transverse component of stress change is more compressive. The significance of time-dependent modification of the initial explosioninduced stress distribution is, however, uncertain.

Fairer, G.M., D.R. Townsend, R.D. Carroll, M.J. Cunningham, D.C. Muller, D.L. Healey, and W.L. Ellis. 1979. U.S.G.S. Investigations in Connection with the Mighty Epic Event, U.12n. I0 Tunnel, Nevada Test Site. USGS-474-228, U.S. Geological Survey, Denver, Colorado.

The tunnel complex consists of two subparailel I, 998-ft-(609-m-)long northwest-trending drifts and various experimental drifts, totaling approximately $5,494 \mathrm{ft}(1,675 \mathrm{~m})$. Fourteen exploratory drill holes were also evaluated in conjunction with the assessment of the Mighty Epic Site.

Fenske, P.R. 1978. Interaquifer Leakage Through Uncased Boreholes Penetrations, Yucca Va.lley, NTS. NV0-1253-13, Desert Research Institute, University of Nevada System, Las Vegas, Nevada.

A method of calculating the ground-water leakage rate into the carbonate aquifer through uncased boreholes is presented. An estimate of leakage rate over a long time interval rather than early transient calculations is required, and the appropriate basic equations are straight-line solutions of the radiat flow equations. Aquifer parameters were estimated on the basis of a few measured values. The leakage rate through one unplugged uncased borehole into the Carbonate Aquifer is on the same order as the total natural leakage through the Tuff Aquitard. The effect of an enhanced leakage rate will be to increase the transport rate of tritium if an uncased unplugged borehole is near an expended nuclear test in either the Alluvial Aquifer or the Tuff Aquitard.

Fenske, P.R., and C.L. Carnahan. 1975. Water Table and Related Maps for NTS and Central Nevada Test Area. NV0-1253-9, Water Resources Center, Desert Research Institute, University of Nevada System, Las Vegas, Nevada.

Water-table maps, water-table gradient maps, and depth-to-water maps have been constructed for the NTS and the central Nevada test area by empirical simulation using a digital computer. Although the digital computer program has been developed specifically for the areas mapped, it is directly applicable to any hydrologic province in which ground-water recharge areâs occur between discharge areas, as in humid regions and the arid Great 8 asin of the western United States. This report presents maps constructed during May 1975, a listing of the water-level control points, and a brief description of the empirical mapping technique. 
Fernald, A.T. 1979. Map of the Tuff Aquitard (Lower Tuff Units) in Yucca Elat, NTS. USGS-474-262, U.S. Geological Survey, Denver, Colorado.

This map is based on data compiled from lithologic logs, many of which had already been compiled and published.

Fernald, A.T. 1983. Study of the Area 3 Sandpile, Southeastern Yucca Flat NTS: Part 1--Geology. USGS-474-315, U.S. Geological Survey, Denver, Colorado.

In Yucca Flat, NTS, a discrete part of Area 3 has been defined where the alluvium is largely tuff-rich sand extending to a depth of $1,500 \mathrm{ft}$ (456 m). Material properties of the alluvial material are nearly uniform. Informally termed the "Area 3 sandpile," knowledge of its extent and nature is based on geologic and geophysical data from $42 \mathrm{dri1}$ sites. For $1,500 \mathrm{ft}$ (456 m) of alluvium to accumulate, the present alluviation pattern must have existed for a considerable time and the structural setting must be stable. This accumuTation may have taken 5 million years or more to develop.

Fitterman, D.V. 1982. Magnetometric Resistivity Survey near Fortymile Wash, NTS, Nevada. USGS-OFR-82-401, U.S. Geological Survey, Denver, Colorado.

This report describes the results of a magnetometric resistivity survey near Fortymile Wash. The work was performed to determine whether the method is useful in locating faults. The field location is near some mapped faults in the vicinity of the Yucca Mountain waste-disposal study area.

French, R.H. 1980. Interim Report on Flash Floods, Area 5, NTS. DOE/DP/1253-19, Water Resources Center, Desert Research Institute, University of Nevada System, Las Vegas, Nevada.

The potential for flash flooding in the vicinity of waste-management sites is an important consideration for siting of such facilities. This report describes research conducted on the potential for flash flooding in Area 5, NTS. This effort is one aspect of a 1 arger research project directed toward assessing the possible migration of radionuclides at the NTS away from proposed and currently used disposal locations.

French, R.H. 1983. Development of Design Hyetographs for Southern Nevada. Publication 45032, Water Resources Center, Desert Research Institute, University of Nevada System, Las Vegas, Nevada.

Traditional1y, drainage facilities are designed from an estimate of the peak flood discharge of a specified return period that is expected to occur in a channel. In small watersheds, particularly those located in the semi-arid and sparsely populated Southwest, measured flood discharge data are often unavailable or unreliable, or cover a very short period of record. However, in many areas of the Southwest, relatively long and accurate records of precipitation may be available even where there are few flow records. In such areas and for small drainages, the use of a design hyetograph and a 
simple watershed model may make it possible to obtain the information regarding the peak discharge that is required for the design of drainage facilities.

The purpose of the work described in the report was to evaluate the historical precipitation records for Well 5B and Cane Spring on the NTS and for McCarran Internationa] Airport in Las Vegas, Nevada, with a view toward developing a generalized, triangular design hyetograph hypothesis for southern Nevada. The following conclusions were reached:

1. The estimated values of the triangular hyetograph parameters apply only to precipitation events lasting longer than two hours.

2. Because the data bases available for the locations examined were sma11, it was not possible to accurately estimate how the hyetograph parameters would vary with both the season and the duration.

3. The hyetograph parameters determined for the Well $5 B$ and Cane Spring stations were not statistically different. However, there is a statistically significant difference between the hyetograph values for these stations and the station located in Las Vegas.

French, R.H., and W.S. Lombardo. 1984. Assessment of Flood Hazard at the Radioactive Waste Management Site in Area 5 of the Nevada Test Site. DOE/NV/10162-15, Publication 45036, Water Resources Center, Desert Research Institute, University of Nevada System, Las Vegas, Nevada.

The purpose of the report was to present the preliminary assessment of flood hazard at the Radioactive Waste Management Site (RWMS) in Area 5 of the NTS. It was concluded that the RWMS is 1 ikely to be hit several times by flash flood events of significant magnitude during its assumed design life of 150 years. Regional peak flood flow equations developed by the USGS and various hypotheses regarding flood processes on alluvial fans were used. A planned berm on the upslope side of the RWMS may offer some protection; the degree of protection provided by this berm was not evaluated.

Although the analysis is subject to a number of limitations, the conclusion is substantiated by the fact that the RWMS is located on a number of alluvial fans which were formed by erosional processes that are still active. Although protective measures for the site can be developed, their development should include the careful consideration of not only the probability that the site will be hit by a flood event, but also the consequences of such flooding. This report does not address the consequences of such flooding. 
Friesen, H.N., and J.C. Brekke. 1979. Hydrologic Data Bank Contents, 1978; User Information Bulletin 5. NVo-1253-15, Water Resources Center, Desert Research institute, University of Nevada System, Las Vegas, Nevada.

The Hydrologic Data System is designed for storing, retrieving, and analyzing numeric data. This document presents general information on the content and status of data files available for retrieval.

Gothaus, B., and N. Howard. 1977. Correlation of Alluvial Deposits at the Nevada Test site. UCRL-52335, Lawrence Livermore Nationa] Laboratory, Livermore, California.

Because characteristics of rock layers and problems in drifling must be studied before radioactive waste can be safely contained, an evaluation was made of methods for correlating alluvial deposits at Yucca Flat. Although correlation of Tertiary volcanic tuff beds at the NTS has been successfully achieved, correlation of stratigraphic zones in the overiying alluvium has posed technical difficulties. Several methods for correlating alluvial deposits from drillholes are evaluated, including electric resistivity logs, visual examination of sidewall samples and comparison of their carbonate content, downhole stereophotography for identifying debris flow deposits, caliche age-dating, and specific yield and permeability measurements of deposits.

Hagstrum, J.T., J.J. Daniels, and J.H. Scott. 1980. Analys is of the Magnetic Susceptibility Well Log in Oril1 Hole UE25a-5, Yucca Mountain, NTS. USGS-OFR-80-1263, U.S. Geological Survey, Denver, Colorado.

The study was undertaken to determine the factor(s) responsible for the variation in magnetic susceptibility measurements from borehole UE25a-5 on the NTS. These well logs and sample analyses are part of a larger geophysical well-logging project studying the physical properties of welded tuffs at the NTS.

Hanson, J.M. 1984. 8arometric Pressure Transient Testing Applications at the NTS: Formation Permeability Analys is. UCRL-15699, Lawrence Livermore National Laboratory, Livermore, Cal ifornia.

Several investigations have been carried out in the past to evaluate the permeability of undisturbed formations at the NTS. These include conventional air-injection tests, analysis of barometric pressure fluctuations, and ground-water pump tests in deep wells on the Pahute Mesa. In spite of these investigations, the question of formation permeability at the NTS remains. This document sets a framework from which the present uncertainty in gas permeability at the NTS can be discussed.

Hanson, J.M. 1985. Barometric Pressure Transient Testing Applications at the NTS: Nuclear Chimney Analysis. UCRL-155770, Lawrence Livermore National Laboratory, Livermore, California. 
Permeability, hydraulic-diffusivity, and migration through fractured volcanics of the NTS are considered.

Harril1, J.R. 1975. Water-Level Changes Associated With Ground-Water Development in Las Vegas Valley, Nevada, 1971-75. Report No, 26, U.S. Geological Survey, Carson City, Nevada.

This report summarizes data collected during a study to evaluate the effects of pumping on ground water in storage in Las Vegas Valley, Nevada. It contains I) a tabulation of water-level measurements made in wells during springs of 1971-1975;2) tables that summarize ground-water pumpage and Lake Mead imports; 3 ) maps showing the distribution of annual pumpage in 1971 1974 ; 4) maps showing annual net changes in water levels during the same period; and 5) hydrographs for nine wells.

Harri11, J. R. 1977. Water-Level Changes Associated With Ground-Water Development in Las Vegas Valley, Nevada, March 1975 to March 1976. Report No. 22, Department of Conservation and Natural Resources, Division of Water Resources, Carson City, Nevada.

Ground-water data collected in Las Vegas Valley between March 1975 and March 1976 are summarized. Ground-water pumpage during 1975 was about 73,000 acre-feet $\left(90,106,455 \mathrm{~m}^{3}\right)$, about 5,000 acre-feet $\left(6,171,675 \mathrm{~m}^{3}\right)$ less than was pumped in 1974. This reduction is a result of increased importation of water from Lake Mead. In 1975, slightly more than 86,000 acre-feet $\left(106,152,810 \mathrm{~m}^{3}\right)$ of Lake Mead water was imported for use in the valley. This represents an increase of nearly 11,000 acre-feet $\left(13,577,685 \mathrm{~m}^{3}\right)$ above 1974 imports. Water levels in deep wells generally recovered sightly, except for wells on the west side of the valley, which continued to decline. Water levels in shallow wells near Las Vegas Wash and in densely populated residential and commercial areas in the central and southeast part of the valley generally rose slightly. Levels in shallow wells in peripheral parts of the valley generally declined.

Harrill, J.R., A.H. Welch, D.E. Prudic, J.M. Thomas, R.L. Carman, R.W. Plume, J.S. Gates, and J.L. Mason. 1983. Aguifer Systems in the Great Basin Region of Nevada, Utah, and Adjacent States: A Study P7an. USGS-0FR-82-445, U.S. Geological Survey, Denver, Colorado.

This is a plan for a four-year study to 1) describe the ground-water systems as they existed under natural conditions and as they exist today, 2) analyze the changes that have led to the systems' present conditions, 3 ) tie the results of this and previous studies together in a regional analysis, and 4) provide means by which effects of future ground-water development can be estimated.

Healey, D.L., F.G. Clutsom, and D.A. Glover. 1984. Borehole Gravity Meter Surveys in Drill Holes USW G-3, UE-25P\# l and UE-25CH1, Yucca Mountain Area. Nevada. USGS-OFR-84-672, U.S. Geological Survey, Denver, Colorado. 
The borehole gravity meter (BHGM) measures a larger volume of rock than a conventional logging tool and provides an independent measurement of the in situ bulk density. Drill holes USW G-3, UE25p\#1, and UE-25c\#l were logged with the BHGM, and free-air gradient measurements were made at UE-25p\#I and UE-25c\#1. The BHGM data from these two holes were reduced using the measured free-air gradients. Windy conditions prevented free-air gradient measurement at USW G-3, and these data were reduced using the assumed "normal" value of $0.3086 \mathrm{mGa} / \mathrm{m}$. At UE-25p\#1 and UE-25c\#1, respective $] y$, the measured free-air gradients are 1.8 and $0.97 \%$ higher and the calculated densities are 0.07 and $0.04 \mathrm{mg} / \mathrm{m}^{3}$ higher than values calculated using the "normal" value. These calculated differences in density are not insignificant and indicate the need to measure the free-air gradient at each logged hole. The interval densities calculated from the three BHGM surveys are presented herein.

Hearst, J.R. 1986. Research on Gas Transport in Chimneys: A Progress Report. UCID-20667, Lawrence Livermore National Laboratory, Livermore, California.

Three general topics are covered: collapse phenomenology, $C_{2}$ content measurement, and gas transport in chimneys. Results so far are fragmentary, but some tentative conclusions were reached: 1) A layer of strong material between depths of 79 and $105 \mathrm{ft}(24$ and $32 \mathrm{~m})$ may have caused the Agrini crater shape. This 1 ayer was absent at the nearby Laban and Crowdie events. ATthough the Tayer could not be located with a surface penetrometer or surface seismic methods, it may be possible to measure strength versus depth in situ by examining the penetration depth of a projectile. 2) Knowledge of the in situ $\mathrm{CO}_{2}$ content can be improved by calibrating a commercial carbon/oxygen logging system for NTS conditions. 3) It is possible to measure the response of the gas in a chimney to changes in atmospheric pressure. Gas transport in chimneys with the same pressure response can be significantly different, depending on the porosity and the distribution of the porosity. An inexpensive experiment can be used to study the gas transport in an existing chimney.

Heuze, F.E., W.C. Patrick, R.V. de 7a Cruz, and C.F. Voss. 1981. In Situ Geomechanics - Climax Granite, NTS. UCRL-53076, Lawrence Livermore National Laboratory, Livermore, Ca]ifornia.

The in situ modulus of the Climax granite in the Spent Fuel Test area of the NTS was estimated using six approaches. The estimate of in situ rockmass deformability was used to back-calculate in situ values for the normal stiffness of the granite joints.

Hodson, J.N., and D.L. Hoover. 1978. Geology and Lithologic Log for Ori11 Hole UE17a, NTS. USGS-1543-1, U.S. Geological Survey, Denver, Colorado.

The UE17a vertical exploratory drill hole is one of a series drilled to evaluate the suitability of unit $J$ of the Eleana Formation as a medium for nuclear-waste storage. Total depth of the drill hole is $1,214 \mathrm{ft}(370 \mathrm{~m})$. The hole penetrated $73 \mathrm{ft}(22.3 \mathrm{~m})$ of alluvium of Quaternary age, $473 \mathrm{ft}$ (144.2 m) of Topopah limestone of Early Pennsylvanian to early Permian(?) 
age, and $668 \mathrm{ft}(203.6 \mathrm{~m})$ of argillite with interbedded quartzite of unit $\mathrm{J}$ of the Eleana Formation of Mississippian age.

Holmes \& Narver, Inc. 1976. Land Subsidence Survey Report. Holmes \& Narver, Inc., Mercury, Nevada.

The seven surveys presented in this report provide vertical control data corresponding with pre- and postshot underground nuclear events, and the normal and major water usage for the period from March 5 through September 22, 1976.

Hoover, D.L., and J.N. Morrison. 1980. Geology of the Syncline Ridqe Area Related to Nuclear Waste Disposal, Nevada Test Site, Nye County, Nevada. USGS-0FR-80-942, U.S. Geological Survey, Denver, Colorado.

The Syncline Ridge area is in the western part of Yucca Flat. Drill holes, geophysical surveys, mapping, and laboratory studies during 1976 through 1978 were used to investigate argillite in unit $\mathrm{J}$ of the Eleana Formation as a possible nuclear-waste repository.

Hoover, D.L., W.C. Swadley, and A.J. Gordon. 1981. Correlation Characteristics of Surficial Deposits with a Description of Surficial Stratigraphy in the Nevada Test Site Reqion. USGS-0FR-81-512, U.S. Geologica? Survey, Denver, Colorado.

Surficial deposits in the NTS region have been correlated between valleys using correlation characteristics, including topography, drainage, topographic relationships, soils, desert pavement, depositional environment, and lithology. The stratigraphic units include Pliocene or Pleistocene debris flows, Pliocene or Pleistocene lakebeds, bedded gravels, and spring deposits, and two Quaternary fluvial and eolian units. The Pliocene or Pleistocene debris flows and the two Quaternary units are separated by regional unconformities. Each of the Quaternary units contains five subunits. The Bishop ash and several radiometric dates have been used to determine the age of the Quaternary units.

Jansma, P.E., D.B. Snyder, and D.A. Ponce. 1983. Principal Facts of Gravity Stations With Gravity and Magnetic Profiles from the Southwest Nevada Test Site, Nye County, Nevada, as of January, 1982. USGS-OFR-82-1041, U.S. Geological Survey, Denver, Colorado.

Three gravity profiles and principal facts of 2,604 gravity stations in the southwest quadrant of the NTS are documented in this report. The residual gravity profiles show the gravity measurements and the smoothed curves derived from these points that were used in geophysical interpretations. The principal data include station level, latitude, longitude, elevation, observed gravity value, and terrain correction for each station, as we 11 as the derived complete Bouguer and isostatic anomalies, reduced at $2.67 \mathrm{~g} / \mathrm{cm}^{3}$. Accuracy codes, where ava $\nmid l a b l e$, further document the data. 
Johnstone, J.K., and K. Wolfsberg. 1980. Evaluation of Tuff as a Medium for a Nuclear Waste Repository: Interim Status Report on the Properties of Iuff. SAND80-1464, Sandia National Laboratories, Albuquerque, New Mexico.

This report is the second in a series of summary briefings dealing with the feasibility of disposal of heat-producing radioactive waste in silicic tuff. The interim status of studies of tuff properties determined on samples obtained from Yucca Mountain and Rainier Mesa located on the NTS is discussed.

Kear1, P.M. 1982. Water Transport in Desert Alluvial Soil. DOE/NV/10162-2, Water Resources Center, Desert Research Institute, University of Nevada System, Las Vegas, Nevada.

Safe storage of radioactive waste buried in an arid alluvial soil requires extensive characterization of the physical processes influencing moisture movement, which could act as a transport medium for the migration of radionuclides. The field portion of this study involved an infiltration plot instrumented with thermocouple psychrometer and neutron-moisture-probe access holes. The baseline information obtained shows a zone of higher moisture content at approximately $5 \mathrm{ft}(1.5 \mathrm{~m})$ in depth. Then a sprinkler system simulated a 500-year precipitation event. Results revealed that water penetrated the soil to $2.9 \mathrm{ft}(0.9 \mathrm{~m})$. Given the low moisture content, it can be concluded that vapor transport was primarily responsible for water movement at this depth. Temperature gradients can cause vapor transport by preferentially sorting water vapor molecules from the surrounding air using the soil as a molecular sieve. Adsorbed and capillary water vapor pressure increases in response to a temperature increase and releases additional water to the soil-pore atmosphere, where it is diffused away.

Knauss, K.G. 1983. Petrologic and Geochemical Characterization of the Bull frog Member of the Crater Flat Tuff: Outcrop Samples Used in Waste Package Experiments. UCRL-53470, Lawrence Livermore National Laboratory, Livermore, California.

Experiments were being conducted with hydrothermal rock/water interaction, corrosion, thermomechanics, and geochemical modeling calculations. All of these activities required characterization of the initial bulk composition, mineralogy, and individual phase geochemistry of the potential repository host rock. This report summarizes the characterization of samples of the Bullfrog Member of the Crater Flat Tuff.

Lahoud, R.G., D.H. Lobmeyer, and M.S. Whitfjeld, Jr. 1984 . Geohydrology of Volcanic Tuff Penetrated By Test We11 UE-25b \#1, Yucca Mountain, Nye County, Nevada. Water Resources Investigations Report 84-4253, U.S. Geological Survey, Denver, Colorado.

Average hydraulic conductivities for stratigraphic units determined from pumping tests, borehole-flow surveys, and packer-injection tests ranged from less than $0.003 \mathrm{ft} / \mathrm{d}(0.001 \mathrm{~m} / \mathrm{d})$ for the Tram Member of the Crater Flat Tuff to $3.6 \mathrm{ft} / \mathrm{d}(1.1 \mathrm{~m} / \mathrm{d})$ for the overlying Bullfrog Member of the Crater Flat 
Tuff. The small values for the Tram Member represented matrix permeability of unfractured rock; the large values near the lower part of the Bullfrog Member were associated with the basal bedded or reworked tuffaceous beds, but probably resulted from fracture permeability. The large hydraulic conductivities of the rhyolitic tuffs of Calico Hills, the Prow Pass Member at the top of the crater Flat Tuff, and the middle of the Bulifrog Member probably resulted from fracture permeability in the ash-flow tuffs. Chemical analyses indicated that the water is a soft sodium bicarbonate type, slightly alkaline, with large concentrations of dissolved silica and sulfate. Uncorrected carbon-14 age dates of the water were 14,100 and 13,400 years.

Langkopf, B.S., and E. Eshom. 1982. Site Exploration for Rock-Mechanics Field Tests in the Grouse Canyon Member, Belted Range Tuff, U12g Tunnel Complex NTS. SAND81-1897, Sandia National Laboratories, Albuquerque, New Mexico.

This report describes site exploration work completed in support of planned rock-mechanics field tests in the Grouse Canyon Member of the Belted Range Tuff at G-Tunne], NTS. As part of this work, the rock-mechanics drift and the rock mass property alcove were mined and three coreholes drilled. The results of mapping and corehole logging are displayed, described, and anaiyzed.

Lin, W. 1978. Measuring the Permeability of Eleana Argillite From Area 17, NTS, Using the Transient Method. UCRL-52604, Lawrence Livermore National Laboratory, Livermore, California.

The transient method is used to determine the permeability of highquartz Eleana argillite from the NTS as a function of effective pressure. By comparing calculated and observed pressure decay in the upstream reservoir, the permeability of intact and fractured specimens was determined at effective pressures ranging from 1.0 to $24.0 \mathrm{MPa}$. Over this pressure range,

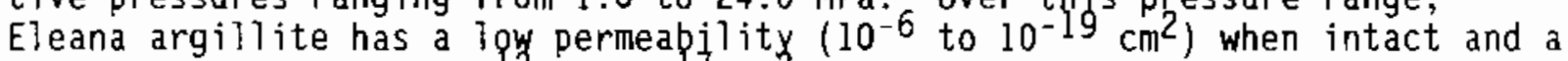
higher permeability $\left(10^{-12}\right.$ to $\left.10^{-17} \mathrm{~cm}^{2}\right)$ with one induced through-going fracture.

Lobmeyer, D.H., M.S. Whitfield, Jr., R.G. Lahoud, and L. Bruckheimer. 1983. Geohydrologic Data for Test We1l UE-25b\#1 NTS, Nye County, Nevada. USGS-0FR-83-855, U.S. Geological Survey, Washington, D.C.

This report presents data collected to determine the hydraulic characteristics of rocks penetrated in test well UE25b\#l. This well is one of a series drilled in and near the southwestern part of the NTS. These investigations are part of an effort to identify suitable sites for storage of highlevel radioactive wastes. Data on drilling operations, lithology, core analyses, borehole geophysics, hydrologic monitoring, hydraulic testing, and ground-water chemistry are reported.

Maldonado, F. 1977. Explosion-Induced Fractures of Selected Announced Underaround Nuclear Tests, Yucca Flat. NTS, Nevada, January through December 1975. USGS-474-234, U.S. Geological Survey, Denver, Colorado. 
From January through December 1975, researchers mapped the surface effects produced by seven underground nuclear tests conducted in Areas 2, 3, 4 , and 7 on Yucca Flat. Surface effects included such features as pressure ridges, fractures, and explosion-induced movements along previously mapped faults. Four tests yielded collapse sinks and mappable surface effects, two produced only sinks, and one test produced neither a collapse sink nor mappable surface effects.

Maldonado, F, 1977. Results from Fault-Monitoring Stations on Pahute Mesa, NTS, from July 1973 through December 1976. USGS-474-242, U.S. Geological Survey, Denver, Colorado.

Seventeen fault-monitoring stations were installed across selected faults on Pahute Mesa, NTS, to monitor fault motions induced from underground nuclear testing. During the monitoring period from July 1973 through December 1976, 12 underground nuclear tests were conducted and fault motions were documented. The data collected show movement induced by the nuclear tests and indicate that long-term fault creep is occurring.

Maldonado, F. 1977. Composite Postshot Fracture Map of Pahute Mesa, Nevada Test Site, June 1973 through March 1976. USGS-474-243, U.S. Geological Survey, Denver, Colorado.

From 1973 to 1976, explosion-induced surface effects were mapped for 13 underground nuclear tests were conducted on Pahute Mesa. Surface effects were predominantly movements along previously mapped faults.

Maldonado, F. 1981. Geology of the Twinridge Pluton Area, NTS, Nevada. USGS-0FR-81-156, U.S. Geological Survey, Denver, Colorado.

Geologic and aeromagnetic data suggest that the Twinridge pluton and the Climax stock, a much larger exposure of granitic rocks to the northwest, may be genetically related and possibly coalesce at depth to form a continuous crystalline body. The evidence for this is I) the approximate coincidence of the Halfpint anticline with exposures of the Twinridge pluton and the Climax stock; 2) the similar mineral compositions of the two exposures; 3 ) possible gravity sliding of Precambrian rocks from the axial trace of the anticline; 4) elongation of aeromagnetic contours and occurrence of highs parallei to the axial trace of the anticline; and 5) distribution of alteration and mineralization parallel to the axial trace of the anticline.

Maldonado, F., D.C. Muller, and J.N. Morrison. 1979. Preliminary Geologic and Geophysical Data of the UE25a-3 Exploratory Drill Hole, Nevada Test Site, Nevada. USGS-1543-6, U.S. Geological Survey, Denver, Colorado.

The UE25a-3 drill hole, located in the Calico Hilis area in the southwestern part of the NTS, was drilled as part of an effort to evaluate the Calico Hills area as a possible nuclear repository site. The purpose was to verify the existence of an intrusive crystalline body below the surface and to determine the stratigraphy, structure, and nature of fractures of the cored rocks. Samples were obtained for mineral, chemical, and material 
property analyses. Continuous cores were taken from $100 \mathrm{ft}(30.5 \mathrm{~m})$ to total depth of $2,530 \mathrm{ft}(771.2 \mathrm{~m})$ of units $\mathrm{J}$ and $\mathrm{I}(?)$ of the Eleana Formation. The drill hole penetrated $1,365 \mathrm{ft}(416.1 \mathrm{~m})$ of argillite, and $999 \mathrm{ft}$ (304.5 $\mathrm{m})$ of thermally altered argillite of unit $\mathrm{J}$, and $166 \mathrm{ft}(50.6 \mathrm{~m})$ of marble of unit I(?). No crystalline rocks were intersected by the drijl hole.

Maldonado, F., S.G. Steele, and D.R. Townsend. 1979. Supplementary Lithologic Logs of Selected Vertical Drill Holes in Area 12, NTS. USGS-474-261, U.S. Geological Survey, Denver, Colorado.

Data presented in this report include locations and lithologies for 1 slant and 22 vertical drill holes greater than $550 \mathrm{ft}(152.4 \mathrm{~m})$ in depth in the Rainier and Aqueduct Mesas, Area 12, NTS, since 1970.

McKague, H.L. 1980. Summary of Measured Medium Properties of Paleozoic Rocks at the Department of Energy Nevada Test Site. UCRL-52884, Lawrence Livermore National Laboratory, Livermore, California.

For this report, selected measurements of the bulk density, grain density, sonic velocity, water content, porosity, and saturation of Paleozoic rocks beneath Yucca Flat were compiled. The bulk density and sonic velocity data show these measurements were within the range established by similar measurements in other areas. Comparisons with values used in TENSOR calculations suggest that the values used in most calculations are sufficiently conservative for containment evaluation.

Metcalf, L.A. 1983. A Preliminary Review and Summary of the Potential for Tectonic, Seismic, and Volcanic Activity at the Nevada Test Site Defense Waste Disposal Site. DOE/NV/10162-7, Water Resources Center, Desert Research Institute, University of Nevada System, Las Vegas, Nevada.

The potential for tectonic, seismic, and volcanic activity, as it relates to a radioactive waste repository in Frenchman Flat on the NTS, is reviewed and summarized. Present seismic and tectonic activity in the NTS region is concentrated along the intersections of the shear zones and in areas of deep basin formation, such as Frenchman Flat.

Natural historic seismicity of the NTS region has been low to moderate. Seismic hazard assessments suggest a probable maximum magnitude 6-7 earthquake, associated with a maximum peak acceleration of $0.7-0.9 \mathrm{~g}$, for the NTS, over a return period of 12,700-15,000 years (a relatively low seismic hazard). It is recommended that a site-specific seismic hazard analysis be conducted for Area 5 because the Cad Spring, Rock Valley, and YuccaFrenchman fault zones are potentially active. Probability calculations for the Yucca Mountain waste repository result in a volcanic disruption hazard of $10^{-8}-10^{-9}$ year. This value is extremely low and is probably also representative of the hazard at Frenchman Flat. However, its tectonic setting may make Frenchman $\mathrm{Flat}$ conducive to future basaltic volcanism; further investigation is needed to properly assess volcanic hazard. 
Metcaif, L.A. 1983. Tephrostratigraphy and Potassium-Arqon Age Determinations of Seven Volcanic Ash Layers in the Muddy Creek Formation of Southern Nevada. DOE/DP/10162-23, Desert Research Institute, University of Nevada System, Las Vegas, Nevada.

Seven silicic tephra layers occur in alluvial deposits of the Muddy Creek and equivalent formations at three localities in southern Nevada. Chemical and petrographic characterization indicate the tephra were derived from seven different volcanic eruptions and do not represent any previously known tephra layers. Potassium-argon determinations on minerals or glass from each layer yielded 6-12 million year ages. Discordant ages were obtained on multiple mineral phases because of the incorporation of detrital contaminants.

Miller, C.H. 1976. A Method for Stress Determination in $N, E$, and $T$ Tunnels, Nevada Test Site, by Hydraulic Fracturing, with a Comparison of Overcoring Methods. USGS-474-222, U.S. Geological Survey, Denver, Colorado.

Twenty-nine intervals in 10 coreholes were hydraulically fractured in $\mathrm{N}$, $E$, and $T$ tunnels, NTS, during 1974. Certain pressures were determined and related to the ambient stress field, but the orientation of the hydraulic fractures was not measured. These data and data from previous investigations in $G$ tunne] indicated that both the magnitude of the hydraulic pressures and the direction of fracturing are independent of the orientation of the core holes.

Monfort, M.E., and J.R. Evans. 1982. Three-Dimensional Modeling of the Nevada Test Site and Vicinity from Teleseismic P-Wave Residuals.

USGS-OFR-82-409, U.S. Geological Survey, Denver, Colorado.

This report describes a teleseismic $P$-Wave trave $-t$ ime residual study that revealed the regional compressional-velocity structure of southern Nevada and neighboring parts of California to a depth of $174 \mathrm{mi}$ (280 km).

Moore, H.J. 1977. "Nevada Test Site Craters Used for Astronaut Training." Journal Research 5(6):719-733.

This paper describes the salient field characteristics of craters produced by chemical and nuclear explosives at the NTS and that were used to train astronauts before their lunar missions.

Muller, D.C., and J.E. Kibler. 1983. Commercial Geophysical Well Logs from the USW G-1 Drill Hole, Nevada Test Site, Nevada, USGS-OFR-83-321, U.S. Geological Survey, Denver, Coforado.

Dril hole USW G-1 was drilled at Yucca Mountain as part of the ongoing exploration program for the NNWSI. Geophysical well logs show only 1 imited stratigraphic correlations, but do correlate reasonably well with the welding of the ash-flow and ash-fall tuffs. Rocks in the upper part of the section have highly variable physical properties, but are more uniform and predictable deeper in the section. 
Murray, W.A. 1981. Geohydrology of the Climax Stock Granite and Surrounding Rock Formations, Nevada Test Site. UCRL-53138, Lawrence Livermore Nationa 1 Laboratory, Livermore, California.

Based on current knowledge and an extrapolation of available geohydrologic data, it appears that the water table may lie at about $3,608-3,936 \mathrm{ft}$ $(1,100-1,200 \mathrm{~m})$ above MSL in the northeastern part of the Climax stock and at about 2,624-2,952 ft (800-900 $\mathrm{m}$ ) in the southwest. A drilling program would be required to establish these levels precisely. The degree of saturation at a given underground elevation can be approximated by a detailed inventory of seeps at that level. More precise determination of degree of saturation would require a water budget.

Ogard, A.E., K. Wolfsberg, and D.T. Vaniman. 1983. Research and Development Related to the NNWSI, April 1 - June 30, 1983. LA-9846-PR, Los A1 amos National Laboratory, Los Alamos, New Mexico.

This report summarizes contributions to the NNWSI for the third quarter of FY 1983.

Orkild, P. P. 1981. "Geology of Nevada Test Site." Paper presented at the Monterey Containment Symposium, Monterey, California, August 26-28, 1981.

The NTS encompasses $1,350 \mathrm{mi}^{2}\left(3,500 \mathrm{~km}^{2}\right)$ in the southern part of the Basin and Range Province and lies along the projected trend of the Walker Lane and the Las Vegas Valley Shear zone. The shear zone location and character as it passes through the NTS are not completely understood, al though stratigraphic and structural evidence indicates an aggregate right-lateral offset of 30 to $45 \mathrm{mi}(48$ to $72 \mathrm{~km})$. Because the shear zone is covered by alluvium, the exact amount of strike-slip movement within the total offset cannot be determined, but recent estimates range from 15 to $20 \mathrm{mi}$ (24 to $32 \mathrm{~km}$ ); the remainder of the offset is attributed to structural bending or "drag". The age of strike-slip movement is thought to be late Miocene to early Pliocene. Alluvium-filled basins make up about $40 \%$ of the area. Paleozoic and uppermost Precambrian sedimentary rocks total about $40,000 \mathrm{ft}$ $(12,192 \mathrm{~m})$ in thickness and form approximately $20 \%$ of the outcrops. In the eastern and southern parts of the NTS, near the thickest part of the Paleozoic cordilleran miogeosyncline, the remainder of the area is covered by mostly Tertiary silicic volcanic rocks, ranging from 27 to 6 million years in age.

Orkild, P.P., and E.C. Jenkins. 1978. Report of Exploration Progress, Pahute Mesa, October 1, 1969, to December 31, 1976. USGS-474-239, U.S. Geological Survey, Denver, Colorado.

Lithologic logs for 80 exploratory, emplacement, and proposed drill holes on Pahute Mesa, NTS, show that the rocks penetrated are Miocene age or younger. The deepest hole drilled, UE20f, bottomed at $13,686 \mathrm{ft}(4,160 \mathrm{~m})$ in pre-Silent Canyon rocks. 
Orkild, P.P., 0.R. Townsend, M.J. Ba]dwin, D.L. Healey, G.D. Bath, J.E. Jahren, and J.G. Rosenbaum. 1983. Geologic and Geophysical Investigations of C] imax Stock Intrusive, Nevada. USGS-0FR-83-377, U.S. Geological Survey, Denver, CoTorado.

This document reports on geological, gravitational, and magnetic investigations of the Climax stock intrusive.

Panian, T.F. 1987. Unsaturated Flow Properties Data Catalog, Volume II. Publication No. 45061, Desert Research Institute, University of Nevada System, Las Vegas, Nevada.

This catalog gives graphs of matric potential versus degree of saturation at several depths for over 150 soils.

Pankratz, L.W. 1982. Reconnaissance Seismic Refraction Studies at Calico Hills, Wahmonie, and Yucca Mountain, Southwest Nevada Test Site, Nye County, Nevada. USGS-OFR-82-478, U.S. Geological Survey, Denver, Colorado.

Reconnaissance refraction surveys for a total of five spreads were conducted in the Calico Hills, Wahmonie, and Yucca Mountain areas. Data from Calico Hills and Wahmonie are generally high in quality; data from Yucca Mountain are for the most part poor.

Pawloski, G.A. 1981. Water Contents of Samples from the NTS: Total, Free, and More Tightly Bonded. UCRL-53130, Lawrence Livermore National Laboratory, Livermore, California.

To heip confirm correct functioning of an epitherma? neutron sonde, tightly bonded water content of selected NTS drill holes was measured. Tuff and alluvium samples were dried overnight at $221^{\circ} \mathrm{F}\left(105^{\circ} \mathrm{C}\right)$. The samples were then heated for $45 \mathrm{~min}$ in a split-tube furnace at $1,292^{\circ} \mathrm{F}\left(700^{\circ} \mathrm{C}\right)$. The water that came off as a result of this heating was collected and the amount recorded. Total water can be calculated for samples from analyses of free and tightly bonded water contents.

Pawloski, G.A. 1982. Results from Exploratory Dri11 Hole UE2ce, Northwest Yucca Flat, Nevada Test Site, near the Nash Event. UCID-19324, Lawrence Livermore National Laboratory, Livermore, California.

The Nash event, with a yield in the 20 - to $200-k i l o t o n$ range, was detonated on January 19, 1967, in emplacement drill hole U2ce. Seismic signais from this event were anomalous. Therefore, a program was undertaken to determine the geologic and geophysical characteristics of selected locations that have demonstrated anomajous seismic signals. Exploratory hole UE2ce was drilled $182 \mathrm{ft}(55.6 \mathrm{~m})$ south of U2ce as part of this program. This report describes the geologic and geophysical data obtained from drill hole UE2ce.

Ponce, D.A., and W.F. Hanna. 1982. Preliminary Appraisal of Gravity and Magnetic Data at Syncline Ridge, Western Yucca Flat, Nevada Test Site, Nye County, Nevada. USGS-OFR-82-931, U.S. Geological Survey, Denver, Colorado. 
A gravity and magnetic study of the Syncline Ridge area was conducted as part of an assessment of a terrain of argillitic rocks under consideration for the possible storage of high-level radioactive waste. The rocks of interest, unit $\mathrm{J}$ of the Eleana Formation, were studied on regional and local scales using a variety of geophysical techniques. The current study focused on a regional study of Bouguer gravity and aeromagnetic anomalies.

Pottorff, E.J., S.J. Erikson, and M.E. Campana. 1987. Hydrologic Utility of Borehole Temperatures in Areas 19 and 20, Pahute Mesa, Nevada Test Site. DOE/NV/10384-19, Publication 45060, Water Resources Center, Desert Research Institute, University of Nevada System, Las Vegas, Nevada.

Borehole temperature logs from Areas 19 and 20 of the NTS were examined in an attempt to obtain quantitative information on the hydrologic regime of Pahute Mesa. A qualitative assessment of the logs proved useful for identifying borehole static water levels and areas of water influx into the borehole. However, the uncertain quality of the data and the effects of borehole convection rendered the data of little value for quantitative analysis. The presence of borehole convection suggests that the borehole thermal profile is not truly representative of the thermal regime in the adjacent porous medium. When static water levels were corrected for the effects of temperature, differences between corrected and uncorrected water levels ranged from 0.03 to $49.65 \mathrm{ft}(0.09$ to $15.13 \mathrm{~m})$. Corrected water levels provide more accurate estimates of hydraulic heads, which in turn provide more accurate estimates of ground-water flow velocities and radionucl ide transport. Therefore, future ground-water studies on the NTS should take into account temperature effects on hydraulic heads.

Quintivan, W.D., and F.M. Byers, Jr. 1977. Chemical Data and Variation Diagrams of Igneous Rocks from the Timber Mountain-0asis Valley Caldera Complex, Southern Nevada. USGS-0FR-77-724, U.S. GeoTogical Survey, Denver, Colorado.

Silica variation diagrams presented here are based on 162 chemical analyses of tuffs, lavas, and intrusives, representative of volcanic centers of the Timber Mountajn-0asis Valley caldera complex and cogenetic rocks of the Silent Canyon caldera. Early effusives of the complex, al though slightly altered, are probably chemically and petrographically more like the calcalkialic Fraction Tuff (Miocene) of the northern Nell is Air Force Base Bombing and Gunnery Range to the north, whereas effusives of later Micoene age, such as the Paintbrush and Timber Mountain tuffs, are alkali-calcic.

Quinlivan, W.D., J.P. Ohl, and P.D. Blackmon. 1977. Lithologic Logs of Selected Exploratory and Emplacement Dri11 Holes in Areas 2 and 8 , Nevada Test Site. USGS-474-227, U.S. Geological Survey, Denver, Colorado.

This report is a compilation of lithologic logs of 27 exploratory and emplacement holes in northern Yucca Flat, with emphasis on Quaternary alluvium and Tertiary volcanic units. An index map showing drill-hole locations is included. 
Ramspott, L.D., and R.D. McArthur. 1977. Results of the Exploratory Dri11 Hole Ue5n, Frenchman Flat, Nevada Test Site. UCID-17392, Lawrence Livermore Nationa] Laboratory, Livermore, California.

Exploratory hole Ue5n was drilled to a depth of $1,686 \mathrm{ft}(514 \mathrm{~m})$ in central Frenchman Flat, NTS, as part of a program to determine the geologic and geophysical parameters of locations with anomalous seismic signals. The specific goal of drilling Ue5n was to provide the site characteristics for emplacement sites U5b and U5e. This report contains data on samples, geophysical logs, lithology and stratigraphy, and depth to the water table. From an analysis of the measurements of the physical properties, a set of values is recommended.

Richard-Haggard, K. 1983. Economic Potential of Alternative Land and Natura7 Resource Uses at the Nevada Test Site, Nye County, Nevada. Pub. No. 45030, Desert Research Institute, University of Nevada System, Las Vegas, Nevada.

Economic potentials of several al ternative 1 and uses at the NTS were estimated. Alternatives considered included mining, agriculture, grazing, and hunting. Two known tungsten-ore bodies are located in the Oak Spring mining district. The economic potential of the reserves is estimated to be $\$ 42,840$. It is aiso possible that there are other economic mineral resources on the NTS whose values are yet unknown. There are an estimated 12,350 acres $(5,000 \mathrm{ha})$ of agricultural land on the NTS; the cash value of alfalfa grown on this acreage is approximately $\$ 564,030$. The economic potential of grazing at the NTS lies in the range of $\$ 10,340$ to $\$ 41,220$. The assumed annual worth of mule deer to hunters is $\$ 90,440$. The gross potential of hunting at the NTS is probabiy somewhat higher if trophy species, game birds, and furbearing animals are also considered. It should be noted that these values indicate gross worth; no costs are included in the estimates.

Richard-Haggard, K. 1983. Demographic Survey Centered Around the Nevada Test Site, Nye County, Nevada. DOE/NV/10162-6, Desert Research Institute, University of Nevada System, Las Vegas, Nevada.

Demographic data were gathered for several small population centers on and around the NTS. Population projections were made for the three townships that include most of the major population centers in the study area, based on the share approach. These townships were Alamo, Beatty, and Pahrump townships. It was estimated that the total population of these three townships, plus Clark County, would reach a maximum of 934,000 people by the year 2000 . It was assumed that the onsite population of the NTS would continue to be a function of activity at the site.

Rush. F.E., W. Thordarson, and L. Bruckheimer. 1983. Geohydrologic and Drill-Hole Data for Test Well USW H-1, Adjacent to Nevada Test Site, Nye County, Nevada. USGS-0FR-83-141, U.S. Geological Survey, Denver, Colorado.

This report presents data collected to determine the hydraulic characteristics of rocks penetrated in test well USW H-I. The well is one of a 
series drilled in and near the southwestern part of the NTS. Data on dri11ing operations, lithology, borehole geophysics, hydrologic monitoring, core analysis, ground-water chemistry, pumping, and injection tests for well USW $\mathrm{H}-\mathrm{l}$ are reported.

Russe11, C.E., J.W. Hess, and S.W. Tyler. 1987. "Hydrogeologic Investigations of Flow in Fractured Tuffs, Rainier" Mesa, Nevada Test Site." Bulletin of the American Geophysical Union, pp. 43-50.

Rainier Mesa is located in the north central area of the NTS and is composed of highly fractured and altered Tertiary tuffs. A hydrogeologic study was conducted within the mesa concentrating on several parameters: the source of ground water found in Rainier Mesa, the period of principal recharge, ground-water travel time between the mesa surface and the study tunnel level, the period of hydraulic response, and total amount of recharge per year to the U12n Tunnel recharge basin. The data base includes the precipitation record, discharge record of seeps within the mesa, the gross chemistry and stable isotopic composition of these seeps, and the results of two tracer studies conducted from the mesa surface. It was concluded that the ground water is of recent meteoric origin. Winter is the period of principal recharge. The period of hydrologic response is at least four months. The total recharge is approximately $8 \%$ of the precipitation that falls on the U12n recharge basin. Trave t time is estimated as longer than one year and less than six. It is certain that nuclear testing since 1957 has altered the hydrogeochemical environment, and some alteration of the hydraulic system may also have occurred.

Sass, J.H., and A.H. Lachenbruch. 1982. Preliminary Interpretation of Thermal Data from the Nevada Test Site. USGS-OFR-82-973, U.S. Geological Survey, Denver, Colorado.

Analyses of data from 60 wells in and around the NTS indicate a thermal regime characterized by large vertical and lateral gradients in heat flow. Estimates of heat flow indicate considerable variation on both regional and local scales. The variations are attributable primarily to hydrologic processes involving interbasin flow with a vertical component of velocity of a few millimeters per year. Apart from indicating a general downward movement of water at a few millimeters per year, the results from Yucca Mountain were inconclusive.

Scott, R.B., G.D. Bath, V.J. Flanigan, D.L. Hoover, J.G. Rosenbaum, and R.W. Spengler. 1984. Geological and Geophysical Evidence of Structures in Northwest-Trending Washes, Yucca Mountain, Southern Nevada, and The ir Possible Significance to a Nuclear Waste Repository in the Unsaturated Zone. USGS-OFR-84-567, U.S. Geological Survey, Denver, Colorado.

Geophysical and geological evidence suggests that five prominent linear northwest-trending washes in the northeastern part of Yucca Mountain are underlain by zones of right-lateral strike-slip faults. Northwest-striking faults exposed along the washes are nearly vertical, have essentially horizontal striations on slickensides, and have small vertical offsets. Cores 
from drill holes within Drill Hole Wash contain northwest-striking steeplydipping fault and fracture planes. Higher conductances and lower resistivities in zones within Drill Hole Wash are interpreted as representing zones of adjacent, less fractured rocks. Little measurable horizontal offset of geomorphic features has occurred along these strike-slip fautts, and strikeslip motion was probably small, even along the longest of these faults. The strikes, sense of motion, geographic position, and age of these Yucca Mountain strike-slip faults are similar to those of the regional Walker Lane-Las Vegas Valley shear zones.

Sinnock, S. 1982. Geology of the Nevada Test Site and Nearby Areas, Southern Nevada. SAND82-2207, Sandia National Laboratories, Albuquerque, New Mexico.

The NTS is characterized by alluvium-filled, topographically closed valleys surrounded by ranges of paleozoic sedimentary rocks and tertiary volcanic tuffs and lavas. Regional compressional and extensional structures, as well as local volcanic structures, occur in the NTS region. Granitic intrusion accompanied compressional thrust-faulting and folding of Paleozoic sedimentary rocks during regional Mesozoic mountain building. Normal extensional faulting coincided with the outbreak of volcanism during the Miocene and was superimposed on existing Mesozoic structures. Extensional deformation may be continuing. Strike-slip faulting and bending along the northwest-trending Las Vegas Valley, Amargosa Desert, and Walker Lane produced as much as 30 to $50 \mathrm{mi}(48$ to $80 \mathrm{~km}$ ) of mid-Tertiary, right-lateral movement in the western Great Basin. Currently local stresses are apparentiy being released along a series of northwest-trending, left-lateral shear zones in the southern portion of the NTS.

Snyder, R.P. 1977. Geology of the Gold Meadows Stock, Nevada Test Site. USGS-474-179, U.S. Geological Survey, Denver, Colorado.

The stock outcrops in an elongate pattern about $1 \mathrm{mi}(1.6 \mathrm{~km}$ ) north of Rainier Mesa. The long axis trends N $35 \mathrm{E}$. Core and cuttings from three drill holes in the stock were analyzed chemically and petrographically. Modally the rock ranges from granodiorite to calc-alkaline granite, and three of five modes indicate that the rock is quartz monzonite. Chemically the rock differs from Nockolds' average quartz monzonite, having more $\mathrm{SiO}_{2}$, slightly less than half the total $\mathrm{Fe}$, one-fourth the $\mathrm{MgO}$, and the same $\mathrm{Na}_{2} \mathrm{O}$ and $\mathrm{K}_{2} \mathrm{O} ; \mathrm{Al}_{2} \mathrm{O}_{3}, \mathrm{CaO}$, and $\mathrm{TiO}$ range downward from slightly less than Nockolds' average to about one-half that much.

Snyder, D.B., and W.J. Carr. 1982, Preliminary Results of Gravity Investigations at Yucca Mountain and Vicinity, Southern Nye County, Nevada. USGS-0FR-82-701, U.S. Geological Survey, Denver, Colorado.

Exploration for a high-level nuclear-waste repository site in the Yucca Mountain area resulted in the addition of 423 new gravity stations from 1980 to 1982 . These new stations plus 934 existing stations provided the data 
base for this study. About 100 surface-rock samples, three borehole gammagamma logs, and one borehole gravity study provide excellent density control.

Spengler, R.W., and V.M. Glanzman. 1980. Review of Geology and Material Property Data in Shallow Alluvium, Eastern Area 2, Nevada Test Site.

USGS-474-266, U.S. Geological Survey, Denver, Colorado.

This review of available geophysical data for pre- and post-1971 dril1 holes in eastern area 2, NTS, shows relatively uniform physical properties within the upper $984 \mathrm{ft}(300 \mathrm{~m})$ of unsaturated alluvium. Studies focused on lithologic variations, principally carbonate-rich intervals and their distribution between drill holes in the area. The data reviewed suggest a higher proportion of carbonate at reference-point depths in the west-central part of the study area.

Spengler, R.W., and J.G. Rosenbaum. 1980. Preliminary Interpretations of Geologic Results Obtained from Boreholes UE-25a-4, $-5,-6$, and -7 , Yucca Mountain Site. USGS-OFR-80-0929, U.S. Geological Survey, Denver, Colorado.

A study of the subsurface geology was undertaken to identify any nearsurface structural features that underlie one of four 1 inear northwesttrending washes that transect the northeastern part of Yucca Mountain at the NTS. Four drill holes were continuously cored to depths of about $500 \mathrm{ft}$ $(152 \mathrm{~m})$. In descending order, the drill holes penetrated the Tiva Canyon, Yucca Mountain, Pah Canyon, and Topopah Spring Members of the Paintbrush Tuff of Tertiary age. These units consist almost entirely of nonwelded to densely welded rhyolitic ash-flow tuffs, separated by thin beds of ash-fall and reworked tuff.

Spengier, R.W., D.C. Muller, and R.B. Livermore. 1979. Preliminary Report on the Geology and Geophysics of Drill Hole UE25a-1, Yucca Mountain, Nevada Iest Site. USGS-OFR-79-1244, U.S. Geological Survey, Denver, Colorado.

This report briefly summarizes some of the geologic aspects of Yucca Mountain and presents a compilation of geologic, hydrologic, and geophysical data derived from the drilling program.

Squires, R.R., and R.L. Young. 1984. Flood Potential of Fortymile Wash and Its Principal Southwestern Tributaries, Nevada Test Site, Southern Nevada. Water Resources Investigations Report 83-4001, U.S. Geological Survey, Denver, Colorado.

Flood hazards for a 9-mi $(14.4-\mathrm{km})$ reach of Fortymile wash and its principal southwestern tributaries were evaluated to aid in determining possible sites for the storage of high-level radioactive wastes on the NTS.

Steele, S.G., and G.M. Fairer. 1978. U.S. Geological Survey Investigations in Connection with the Dining Car Event, U12e. I8 Tunnel, Rainier Mesa, Nevada Test Site. USGS-474-246, U.S. Geological Survey, Denver, Colorado. 
The Dining Car event was a nuclear weapons test located in the U12e.18 drift of the E-tunnel complex, central Rainier Mesa, Area 12, NTS. The physical properties of core samples are typical for the tunnel beds and compare well with those of other tunnel sites. Site geology and geophysical investigations were made in one vertical and two horizontal drill holes before the U12e.18 drift was mined. Structural features, electric logs, seismic velocities, and stresses were investigated.

Swadiey, W.C., and D.L. Hoover. 1983. Geology of Faults Exposed in Trenches in Crater FIat, Nye County, Nevada. USGS-DFR-83-608, U.S. Geological Survey, Denver, Colorado.

This study of three trenches excavated across two faults along the eastern edge of Crater Flat indicated that the main fault movement had offset unit QTa in trench 1 at least $7.9 \mathrm{ft}(2.4 \mathrm{~m})$ down to the west and had occurred about 1.1 million years ago, as indicated by included basalt ash. Later fault movement, detected in trench 3 , and probably related to the faulting at trench 1 , displaced unit Q2C a combined distance of $2.6 \mathrm{ft}(0.8 \mathrm{~m})$ down to the west along three faults. Fault movement at trench 3 occurred sometime between 260,000 years and 40,000 years ago; the evidence favors an age that is closer to the older date.

Sykes, M.L., G.H. Heiken, and J.R. Smyth. 1979. Mineralogy and Petrology of Tuff Units from the UE25a-1 Drill Site, Yucca Mountain, Nevada. LA-8139-MS, Los Alamos National Laboratory, Los Alamos, New Mexico.

Thick sequences of zeolitized tuff may form effective natural barriers against ground-water migration of radionuclides from radioactive-wasteisolation facilities. In the Yucca Mountain area of the NTS, drill hole UE25a-l has penetrated tuffs of Tertiary age that contain two major zeolitized horizons at depths below $1,246 \mathrm{ft}(380 \mathrm{~m})$. These horizons are restricted to low-density, high-porosity nonwelded tuffs below the basal vitrophyre of the Topopah Springs Member of the Paintbrush Tuff, and they interfinger with more densely welded devitrified tuffs of granophyric mineralogy. Zeolites occur as glass pyroclast replacement, vug 1 inings, and fracture fillings. Nonwelded units above the welded portion of the Topopah Springs Member are essentially unaltered, indicating that they have never been ground-water-saturated for any significant length of time.

Szabo, B.J., and P. A. O'Malley. 1985. Uranium-Series Dating of Secondary Carbonate and Si] ica Precipitates Relating to Fault Movements in the Nevada Test Site Region and of Caliche and Travertine Samples from the Amargosa Desert. USGS-OFR-85-47, U.S. Geological Survey, Denver, Colorado.

Fault-associated secondary carbonate and opal samples from the NTS area, together with travertine samples from the Amargosa Desert, were dated by the uranium-series disequilibrium method. Analyses of secondary carbonate samples from Yucca Mountain and from Crater and Yucca Flats yielded minimum ages for the last significant displacements of associated faults that were between 27,000 and 219,000 years. For an opaline carbonate rock sample from a fault on the east side of Yucca Mountain, dating results show that the age 
of the deposit is greater than 360,000 years. Two dates for travertine vein samples show that spring discharge was occurring before about 360,000 years ago in the Kinney area of the Amargosa Desert. Ages obtained for travertine 1 aminae from the Furnace Creek Wash area suggest that significant movement occurred along this low-angle fault more than 132,000 years ago.

Szabo, B.J., W.J. Carr, and W.C. Gottschal1. 1981. Uranium-Thorium Dating of Quaternary Carbonate Accumulations in the Nevada Test Site Region, Southern Nevada. USGS-OFR-81-119, U.S. Geological Survey, Denver, Colorado.

Carbonate samples were subjected to a complex treatment process, and the resulting preparations were counted on an alpha spectrometer. Some of the samples from obviously closed systems yielded reasonable ages; others gave only a minimum age for a material or event. Many of the ages obtained agreed well with estimates of age determined from dated volcanic units, fault-scarp morphology, and displaced alluvial units.

Thordarson, W. 1983. Geohydrologic Data and Test Results from Well J-13, Nevada Test Site, Nye County, Nevada. Water Resources Investigations Report 83-4171, U.S. Geological Survey, Denver, Colorado.

We11 J-13 was drilied to a depth of $3,487 \mathrm{ft}(1,063.1 \mathrm{~m})$ by using airhydraulic-rotary drilling equipment. The well penetrated $448 \mathrm{ft}(135.6 \mathrm{~m})$ of alluvium of Quaternary and Tertiary (?) age and 3,042 ft $(927.5 \mathrm{~m})$ of tuff of Tertiary age. Pumping tests were performed to obtain transmissivities and the hydraulic conductivity. Ground water sampled from the welt is a sodium bicarbonate water containing small concentrations of calcium, magnesium, silica, and sulfate. The apparent age of the water, derived from ${ }^{14} \mathrm{C}$ dating, is 9,900 years.

Thordarson, W., F.E. Rush, R.W. Spengler, and S.J. Wadde 11. 1984. Geohydrologic and Drill-Hole Data for Test Well USW H-3, Yucca Mountain, Nye County Nevada. USGS-OFR-84-149, U.S. Geological Survey, Denver, Colorado.

This report presents data collected to determine the hydraulic characteristics of rocks penetrated in test well USW H-3. The well is one of a series drilled in and near the southwestern part of the NTS to identify suitable sites for storage of high-level radioactive wastes. Data on drilling operations, lithology, borehole geophysics, hydrologic monitoring, pumping, swabbing, and injection tests for the well are contained in this report.

Thordarson, W., F.E. Rush, and S.J. Wadde]1. 1985. Geohydrology of Test Well USW H-3, Yucca Mountain, Nye County, Nevada. Water Resources Investigations Report 84-4272, U.S. Geological Survey, Denver, Colorado.

The composite hydraulic head in the zone from 2,463 to $3,998 \mathrm{ft}$ (75l to $1,219 \mathrm{~m})$ was $2,404 \mathrm{ft}(733 \mathrm{~m})$ above sea level, and at a depth below the 7 and surface of 751 meters. Below a depth of $3,903 \mathrm{ft}(1,190 \mathrm{~m})$, the hydraulic head was at least $2,473 \mathrm{ft}(754 \mathrm{~m})$ above sea level, suggesting an upward component of ground-water flow at the site. 
The most transmissive part of the saturated zone is in the upper part of the Tram Member of the Crater Flat Tuff, in the depth interval from 2,654 to $2,758 \mathrm{ft}(809$ to $841 \mathrm{~m})$, with an apparent transmissivity of about $7.6 \mathrm{ft}^{2}$ $\left(0.7 \mathrm{~m}^{2}\right)$ per day. The remainder of the penetrated rocks in the saturated zone, 2,758 to $3,998 \mathrm{ft}(841$ to $1,219 \mathrm{~m})$, has an apparent transmissivity of about $4.32 \mathrm{ft}^{2}\left(0.4 \mathrm{~m}^{2}\right)$ per day. The most transmissive part of the lower depth interval is in the bedded tuff and Lithic Ridge Tuff, in the depth interval from 3,634 to $3,673 \mathrm{ft}(1,108$ to $1,120 \mathrm{~m})$. The apparent hydraulic conductivity of the rocks in the lower depth inferval from 2,758 to $3,673 \mathrm{ft}$ $(841$ to $1,210 \mathrm{~m})$ commonly ranges from about $10^{-1}$ to $10^{-4}$ meter per day.

Townsend, D.R., M.J. Baldwin, R.D. Carroll, W.L. Ellis, and J.E. Magner. 1982. Geologic, Geophysical, and In Situ Stress Investigation in the Vicinity of the Dining Car Chimney, Dining Car/Hybla Gold Drifts, Nevada Test Site. USGS-0FR-82-137, U.S. Geological Survey, Denver, Colorado.

The Hybla Gold experiment was a low-yield nuclear event located in the U12e.20 drift of the E-tunnel complex in Rainier Mesa, NTS. The event was detonated on November 1, 1977. The location of the Hybla Gold event was unique in that it was near the expended Dining Car event, a low-yield nuclear event detonated in the U12e.18 drjft on May 4, 1975. The main drift of the Hybla Gold complex passed within $9.8 \mathrm{ft}(3 \mathrm{~m})$ of the chimney formed by the collapse of the Dining Car cavity. As a result, the Hybla Gold drift mining enabled the most extensive examination of postshot tunnel reentry in the chimney region; measurements in the Hybla Gold drift complex have added extensively to that experience.

Tyler, S.W. 1987. Review of Soil Moisture Flux Studies at the Nevada Test Site, Nye County, Nevada. DOE/NV/10384-17, Publication 45058, Water Resources Center, Desert Research Institute, University of Nevada System, Las Vegas, Nevada.

This report summarizes the results of almost 30 years of research on the movement and recharge of soil moisture at the NTS. Although data are scarce, three distinct topographic zones are represented: alluvial valleys, inundated terrains, and upland terrain. Recharge in alluvial valleys was found to be very small or negligible. Ponded areas, such as playas and subsidence craters, showed significant amounts of recharge. In the upland terrains, Rajnier Mesa shows active recharge of up to $3 \%$ of the annual average precipitation in fractured volcanic tuff.

Tyler, S.W., W.A. Mckay, J.W. Hess, R.L. Jacobson, and K. Taylor. 1986. Effects of Surface Collapse Structures on Infiltration and Moisture Redistribution. DOE/NV/10384-04, Publication 45045, Water Resources Center, Desert Research Institute, University of Nevada System, Las Vegas, Nevada.

Two boreholes were completed in and adjacent to subsidence crater U3fd on the NTS. The holes were 152 and $101 \mathrm{ft}(46.4$ and $30.7 \mathrm{~m})$ deep and were to determine how subsidence structures affect subsurface mojsture migration. Analysis of core and borehole geophysical tests indicated that the average 
volumetric water content of the soil profile [to a depth of $97 \mathrm{ft}(29.8 \mathrm{~m})$ below the crater bottom] was $100 \%$ greater than that of soils in the adjacent und isturbed area.

Hydraulic conductivity and hydraulic gradient values from core samples indicated that a downward water flux (expressed as a volume per unit area per time) of between 1.7 and $13.8 \mathrm{ft}(0.54$ and $4.22 \mathrm{~m})$ per year is occurring directly below the crater bottom. Downward flux conditions were observed throughout the entire $152-\mathrm{ft}(46.4-\mathrm{m})$ profile drilled below the crater. Core data from the undisturbed environment indicate that if any downward flux or recharge is occurring in this area, it is negligible.

Surface resistivity data taken at both areas show considerably lower soil resistance in the disturbed area. However, other environmental factors (buried metal objects, soil compaction, and sait leaching) limit the usefulness of resistivity for determining the quantity and extent of infiltrated water.

U.S. Department of Energy (DOE). 1986. Yucca Mountain Site, Nevada Research and Development Area, Nevada. D0E/RW-0073, U.S. Department of Energy, Washington, D.C.

In February 1983, the Yucca Mountain site in Nevada was identified as a potentially acceptable site for a mined geologic repository for spent nuctear fuel and high-level radioactive waste. The site is in the Great Basin, one of five distinct geohydrologic settings considered for the first repository. To determine its suitability, the Yucca Mountain site has been evaluated in accordance with the DOE's General Guidelines for the Recommendation of Sites for the Nuclear Waste Repositories.

On the basis of the evaluations reported in this environmental assessment, DOE found that the Yucca Mountain site is not disqualified under the guidelines. DOE a] so found that the evidence did not support a conclusion that the site would not be able to meet each of the qualifying conditions specified in the guidelines. On the basis of these findings, $00 E$ nominated the Yucca Mountain site as one of five sites suitable for characterization.

U.S. Geological Survey (USGS). 1978. U.S. Geological Survey Investigations in Connection with the Dining Car Event, U12e.18 Tunnel, Rainier Mesa, Nevada Test Site. USGS-474-246, U.S. Geological Survey, Denver, Colorado.

The Dining Car event was a nuclear weapons test located in the U12e.18 draft of the E-tunnel complex, central Rainier Mesa, Area 12, NTS. The main drift and bypass drift were mined in zeoljtized tuff to a total length of $1,785 \mathrm{ft}(544 \mathrm{~m})$. The overburden thickness above the experiment is approximately $1,300 \mathrm{ft}(396 \mathrm{~m})$ in the U12e.18 area. The pre-Tertiary surface, which is probably not quartzite in this area, is located approximately $800-900 \mathrm{ft}$ (243.8-274.3 m) below tunnel level. The physical properties of core samples are considered typical for the tunnel beds and compare well with those of other tunnel sites. Site geology and geophysical investigations were made in one vertical and two horizontal drill holes prior to mining of the U12e.18 
drift. Electric logs in the two horizontal holes indicate no extensive zones of argillization which might create problems in tunnelling. This was subsequentiy confirmed by mining. Geophysical logs in the vertical exploratory hole suggest that the tuff is saturated at a depth of about $800 \mathrm{ft}(244 \mathrm{~m})$. Seismic velocities obtained in the tunnel after mining compare favorably with sonic velocities obtained in one hole by means of a sonic probe, indicating that the bulk geologic structure is not significant in affecting seismicwaive propagation. This condition is not always observed in such comparisons. A repeat seismic survey in the tunnel showed no change in seismic velocity four months after mining.

U.S. Geological Survey (USGS). 1984. A. Summary of Geologic Studies Through January 1, 1983, of a Potential High-Level Radioactive Waste Repository Site at Yucca Mountain. Southern Nye County, Nevada. USGS-0FR-84-792, U.S. Geological Survey, Denver, Colorado.

Yucca Mountain, located at the southwest corner of the NTS, is being investigated as a potential site for the storage of high-level radioactive waste. Sequences of ash-flow tuff like those at Yucca Mountain could potentially provide multiple geologic barriers against the release of nuclear waste, assuming that the geologic and hydrogeologic settings of the site are favorable. This report describes the geology of the Yucca Mountain site and presents preliminary conclusions on the basis of work in progress. The subsurface structure above about $0.6 \mathrm{mi}(1 \mathrm{~km})$ depth at Yucca Mountain is similar in style and complexity to surface structure. Subsurface data indicate that fracturing, which is of fundamental concern in understanding hydrology and evaluating mining conditions at the site, is most extensive in brittle rock types such as densely welded tuff.

Waddel1, R.K., Jr. 1985. Hydrologic and Drill-Hole Data for Test Wells UE-29a\#l and UE-29a\#2, Fortymile Canyon, Nevada Test Site. USGS-0FR-84-142, U.S. Geological Survey, Denver, Colorado.

The two wells were drilled in Fortymile Canyon as part of the DOE's program to study the feasibility of constructing a high-level nuclear-waste repository beneath Yucca Mountain. The wells were designed to obtain data pertinent to characterizing the regional ground-water flow system near Yucca Mountain.

WaddelT, R.K., J.H. Robison, and R.K. Blankennagel. 1984. Hydrology.of Yucca Mountain and Vicinity. Nevada-Cal ifornia--Investigative Results Through Mid-1983. Water Resources Investigations Report 84-4267, U.S. Geological Survey, Denver, Colorado.

Yucca Mountain, Nevada, is one of several sites under consideration for construction of the first repository for high-level nuclear waste. This site is underlain by at least $5,904 \mathrm{ft}(1,800 \mathrm{~m})$ of volcanic tuffs of Tertiary age that are offset by westward-dipping norma? faults. Sedimentary rocks of Precambrian and Paleozoic age, primarily limestones and dolomites with some quartzites and slightly metamorphosed shales, stratigraphically underije volcanic rocks in much of the area. 
Wagoner, J.L., and L.D. Ramspott. 1981. Results of Exploratory Dri11 Hole UE7nS, East-Central Yucca Flat, Nevada Test Site. UCID-18979, Lawrence Livermore National Laboratory, Livermore, California.

Exploratory hole UE7nS was drilled to a depth of 2,204 ft $(672.1 \mathrm{~m})$. The purpose was to provide geologic and geophysical characteristics of emplacement site U7n, which had demonstrated anomalous seismic signals. This report presents lithologic and stratigraphic descriptions, geophysical logs, physical properties, and water-table measurements. An anaiysis of these data has been made, and a set of recommended values is presented.

Weeks, E.P., and W.E. Wilson. 1984. Preliminary Evaluation of Hydrologic Properties of Cores of Unsaturated Tuff, Test Well USW H-1, Yucca Mountain, Nevada. Water Resources Investigations Report 84-4193, U.S. Geological Survey, Denver, Colorado.

Analyses were made on 19 core samples of unsaturated tuff from test well USW $\mathrm{H}-1$. Moisture-characteristic curves relating saturation and moisture tension were developed from results of mercury-injection tests. Ambient moisture tension estimated from these curves was generally 100 to $200 \mathrm{KPa}$. Values of relative permeability ranging from about 0.002 to 0.01 were determined by fitting an analytical expression to eight of the moisturecharacteristic curves and then integrating to solve for relative permeability.

White, A.F. 1979. Geochemistry of Ground Water Associated with Tuffaceous Rocks, Oasis Valley, Nevada. Professional Paper 712-E, U.S. Geological Survey, Denver, Colorado.

Regional similarities and trends in the aqueous chemistry indicate that probabiy most of the recharge entering the 0asis Valley ground-water system is the result of ground-water inflow from Pahute Mesa, Gold Flat, and other areas to the north and east. Mass-balance calculations show that about half of the water recharged to Oasis Valley discharges through evapotranspiration, and the rest exits by flow through the alluvium southward toward the Amargosa Desert.

Most of the water in the basin has moved from areas of recharge in the highlands through the fracture system in the tuffaceous rocks to the alluvial material in the valley floor. The solute concentrations of sodium and silica suggest that hydrolysis and incongruent dissolution of volcanic glass are the principal reactions in the tuffaceous aquifer.

Ground water infiltrates the alluvial aquifer from the tuffs via springs and subsurface flow. The proximity of the water table in the alluvium to the ground surface promotes evapotranspiration, and evapotranspiration causes a decrease in the volume of ground water and an increase in chemical concentrations. Collinear increases in concentrations of selected solute species demonstrate that water contained in both the tuffaceous aquifer and the alluvium has the same generic origin. Concentrations of specific elements are discussed in more detail. 
White, A.F., H.C. Claassen, and L.V. Benson. 1980. The Effect of Dissolution of Volcanic Glass on the Water Chemistry in a Tuffaceous Aquifer, Rainier Mesa, Nevada. Professional Paper 1535-Q, U.S. Geological Survey, Denver, Colorado.

The geochemistry of ground water associated with Tertiary tuffs within Rainier Mesa was investigated to determine the relative importance of glass dissolution in controlling water chemistry. Water samples were obtained both from interstitial pores in core sections and from free-flowing fractures. Cation compositions showed that calcium and magnesium decreased as a function of depth in the mesa, while sodium increased. The maximum effect occurs within alteration zones containing clinoptilolite and montmorillonite, suggesting that these minerals effectively remove bivalent cations from the system.

Whitfield, M.S., Jr., W. Thordarson, and E.P. Eshom. 1984. Geohydraulic and Drill-Hole Data for Test Well USW H-4, Yucca Mountain, Nye County, Nevada. USGS-OFR-84-449, U.S. Geological Survey, Denver, Colorado.

This report presents data collected to determine the hydraulic char acteristics of rocks penetrated in test well USW H-4. The well is one of a series drilled in and near the southwestern part of the NTS to identify suitable sites for storage of high-level radioactive wastes. Data on drilling operations, lithology, borehole geophysics, hydrologic monitoring, pumping, swabbing, and injection tests for the well are contained in this report.

Winograd, I.J. 1963. A Summary of the Ground-Water Hydrology of the Area Between the Las Vegas Valley and the Amargosa Desert, Nevada. TEI-840, U.S. Geological Survey, Denver, Colorado.

Three general areas in the vicinity of Mercury, Nevada, were being considered for development of a town to facilitate operations at the NTS. The hydrologic environment in which the townsite water supplies might be deve?oped and how pumping at each of several potential townsites would affect other water supplies are summarized in this report.

Winograd, I.J., and G.C. Doty. 1980. Paleohydrology of the Southern Great Basin, with Special Reference to water Table Fluctuations Beneath the Nevada Test Site During the Late(?) Pleistocene. USGS-OFR-80-127, U.S. Geological Survey, Denver, Colorado.

The magnitude of water-tabie rise during Pleistocene pluvial climates, and of the resultant shortening of ground-water flow path and reduction in unsaturated zone thickness, must be known for a technical evaluation of the NTS or other arid zone sites as repositories for high-level or transuranic element radioactive wastes. The distribution of calcitic veins filling fractures in alluvium and of tufa deposits between the Ash Meadows spring discharge area and the NTS indicates that discharge from the regional Paleozoic carbonate aquifer during the Late(?) Pleistocene pluvial periods may have occurred at an altitude about $164 \mathrm{ft}(50 \mathrm{~m})$ higher than at present and $8.7 \mathrm{mi}(14 \mathrm{~km})$ northeast of Ash Meadows. Use of the underflow equation 
and various assumptions regarding pluvial recharge, transmissivity, and altitude of ground-water base level suggest possible rises in potentionetric level in the carbonate aquifer of about 23-295 ft (7-90 m) beneath central Frenchman Flat. Water level rises beneath Frenchman Flat during future pluvials are unlikely to exceed $98 \mathrm{ft}(30 \mathrm{~m})$ and might even be $32 \mathrm{ft}(10 \mathrm{~m})$ lower than modern levels.

Winograd, J.I., and W. Thordarson. 1975. Structural Control of GroundWater Movement in Miogeosynclinal Rocks of South-Centra] Nevada. Memoir 110, Geological Society of America, Denver, Colorado.

In south-central Nevada, major wrench, thrust, and normal faults and folds exert marked control on ground-water movement. Deformation of the carbonate rocks results in regions of high transmissibility, but juxtaposition of thick clastic strata against carbonate aquifers by faulting or folding results in prominent ground-water barriers, some of which are more than $10 \mathrm{mi}(16 \mathrm{~km})$ long. The apparent hydraulic gradients across the thick clastic aquitards vary from 150 to $1300 \mathrm{ft}$ per mile $(28$ to $245 \mathrm{~m}$ per $\mathrm{km}$ ); by contrast, gradients in the adjacent carbonate aquifers vary from 0.5 to $10 \mathrm{ft}$ per mile $(0.09$ to $1.9 \mathrm{~m}$ per $\mathrm{km})$. Barriers may also result from gouges developed along the major fault zones. In upland areas, the clastic aquitards may exert control on distribution of recharge. Where present in central parts of the flow system, the aquitards act as prominent ground-water dams and localize minor spring discharge. In discharge areas, they localize major spring lines.

Young, R.A. 1972. Water Supply for the Nuclear Rocket Development Station at the U.S. Atomic Energy Commission's Nevada Test Site. Water Supply Paper 1938, U.S. Geologica] Survey, Denver, Colorado.

This report covers investigations of ground-water supply in the vicinity of the Nuclear Rocket Development Station. The principal objectives were to delineate the welded-tuff aquifer, to identify the chemical quality of water in the aquifer, to estimate the quantity of water in storage and how long the supply would last under the expected rate of use, and to recommend sites for future well development.

Zohdy, A.A.R., and R.J. Bisdorf. 1979. Schlumberger Soundings and Geoelectric Cross-Sections in Yucca Lake, Nevada Test Site, Nevada.

USGS-0FR-79-220, U.S. Geological Survey, Denver, Colorado.

In 1977, the USGS made 52 symmetric Schlumberger resistivity soundings in the Yucca Lake area, NTS. The purpose of the survey was to study the large cracks that have opened successively in the lake deposits, from the late 1940 s to 1969. 


\section{B. Distribution and Transport of Radionuclides at the NTS}

Barnes, M.G., J.J. Giacomini, R.T. Reiman, and B. El]iot. 1980. Nevada Test Site Radiological Assessment Project: Results for Frenchman Lake Region of Area 5. DOE/DP/01253-17, Desert Research Institute, University of Nevada Systern, Las Vegas, Nevada.

The general objective of the NTS Radiological Assessment Project is a detailed characterization of radionuclide activity, expressed as estimates of area averages for each isotope of interest. This report includes the characterization of the Frenchman Lake region of Area 5 for the isotopes $24 \mathrm{Am}_{\mathrm{Am}}$, $155 \mathrm{Eu}, 152 \mathrm{Eu},{ }^{13} 7_{\mathrm{Cs}}, 60_{\mathrm{Co}}$, and $239_{\mathrm{Pu}}$.

Benson, L.V. 1976. Mass Transport in Vitric Tuffs of Rainier Mesa. NV0-1253-10, Desert Research Institute, University of Nevada System, Las Vegas, Nevada.

Chemical and physical analyses of reactant and product phases found in subaerially-exposed vitric tuffs of Rainier Mesa indicate that digenetic alteration is occurring. Variations in the composition of the fluid phase with depth suggest a predominantly vertical transport process, whereby the dissolution of metastable glass drives the sequential precipitation of montmorillonite, clinoptilolite, and possibly analcime. Mordenite was found to occur in patches within the clinoptilolite zone.

Benson, L.V., J.H. Robison, R.K. Blankennagel, and A.E. Ogard. 1983. Chemical Composition of Ground Water and the Locations of Permeable Zones in the Yucca Mountain Area, Nevada. USGS-0FR-83-854, U.S. Geological Survey, Denver, Colorado.

Ten wells in the Yucca Mountain area of southern Nevada were sampled for chemical analysis. Samples were obtained during pumping of water from the entire well bore and in one instance by pumping water from a single isolated interval in well UE-25b\#1. Sodium is the most abundant cation and bicarbonate the most abundant anion in all water samples. Although the general chemical compositions of individua samples are similar, there are significant differences in uncorrected $14 \mathrm{C}$ age and in inorganic and stable-isotope. composition. Flow surveys of seven wells performed using $131_{I}$ as a tracer indicate that ground-water production is usually from one or more discrete zones of permeability.

Bl ankennage 1, R., P.R. Fenske, and L.D. Ramspott (Steering Committee). 1986. Radionuclide Migration Program Strategy Document. NVO-298, U.S. Department of Energy, Nevada Operations Office, Las Vegas, Nevada.

The Radionuclide Migration Program is composed of a group of projects that have evolved since 1976 to obtain data that will define the hydrologic system on the NTS and determine what radionuclides are available for migration in that system. 
Borg, I.Y., R. Stone, H.B. Levy, and L.D. Ramspott. 1976. Information Pertinent to the Migration of Radionuclides in Ground Water at the Nevada Test Site, Part 1: Review and Analysis of Existing Information. UCRL-52078, Pt. 1, Lawrence Livermore National Laboratory, Livermore, California.

This report is a comprehensive, detailed review of what is known concerning migration of radionuclides in ground water at the NTS. A history of the NTS is given, the geologic and hydrologic setting is described, and the amount of radioactivity deposited within and near the main aquifers is estimated. The laboratory and field investigations into general processes retarding the movement of radioactivity from the source and dispersing its concentrations are described, together with results of programs designed to monitor the source terms and the movement of radioactivity at the site. (A second volume, Part 2: Annotated Bibliography, includes summaries of the documents reviewed.)

Borg, I.Y., R. Stone, H.B. Levy, and L.D. Ramspott, 1977. Movement of Radioactivity Deposited Underground at the Nevada Test Site. UCRL-78670, Lawrence Livermore National Laboratory, Livermore, California.

Movement of radioactivity has been minimal at the NTS, as a result of the low rainfall in the area and the general phenomenology of nuclear explosions. Most refractory fission products and unspent fuel are captured in the lithological glasses produced by the explosion, and water is forcefuliy ejected from the immediate vicinity of the explosion. The return of the water to the rubblized site inaugurates leaching and consequent mobilization of nuclides. The slow to moderate movement of the ground water in the aquifer within northern portions of the NTS has kept slow the movement of tritium, the most mobile of the radionuclides. Sorptive processes are especially important in retarding nuclide movement at the NTS. The altered tuffaceous rocks, which make up a large portion of the rock in the saturated zone, are rich in zeolites and clays that effectively absorb many radionuclides moving through the formation. As of 1977 , no radioactivity had been detected beyond the bounds of the NTS nor within any of the approximately 32 water wells within or beyond the boundaries of the site. All water used at the site continued to come from wells not far from areas of active underground testing.

Buddemeier, R.W. 1988. Hydrology and Radionuclide Migration Program 19851986 Progress Report. UCRL-53779, Lawrence Livermore National Laboratory, Livermore, California.

This report presents results from the Hydrology and Radionuclide Migration Program at the NTS during FY 1985 and FY 1986. The report discusses 1) studies of the partitioning and movement of dissolved and colloidal radionuclides at the Cheshire (U2On) site; 2) tracer studies of shallow recharge and plant-water uptake at the Cambric site ditch, which carries the effluent water pumped from well RNM-2; 3) development of a rapid and sensitive assay for ${ }^{99} \mathrm{Tc}$ in ground water and its application to a survey of technetium activities at a variety of test wells;4) and a series of studies 
directed toward calibrating, understanding, and improving the low-level radionuclide determinations made by LLNL.

Buddemeier, R.W., and D. Isherwood. 1985. Radionuclide Migration Project 1984 Progress Report. UCRL-53628, Lawrence Livermore National Laboratory, Livermore, California.

This report presents previously unpublished results from the Lawrence Livermore National Laboratory's participation in the Radionuclide Migration Project at the NTS. The report discusses the hydrogeologic settings and histories of studies associated with the Cheshire (U20n), Cambric (U5e), Nash (UE2ce), Bilby (U3Cn), Bourbon (U7n), and Faultless (UCl) events. Radionuclide and some chemical data are presented for water samples from cavity or chimney wells associated with the Cheshire, Cambric, and Bilby events, and from satellite wells at the Cambric, Nash, Bilby, Bourbon, and Faultless event sites.

The report also gives the results of studies of specific sampling or analytical methodologies. These studies demonstrated that the apparent migration of $155_{\mathrm{Eu}}$ was an artifact of spectrometric misidentification of gamma- and $x$-ray peaks from other constituents. A potential problem with atmospheric contamination of samples collected with evacuated thief samples was also identified. Ultrafiltration techniques were applied to some of the Cheshire cavity samples collected, and preliminary resuits suggest that substantial amounts of activity may be associated with colloidal particles in the size range of 0.006 to $0.45 \mathrm{~mm}$. This report also gives the initial results of unsaturated zone studies showing the propagation of moisture and tritium fronts through the shallow soil. In addition, geochemical modeling of the behavior of ruthenium and technetium was carried out, with particular emphasis on the identification of ionic species that would be potentially mobile under NTS ground-water conditions.

Burbey, T.J., and S.W. Wheatcraft. 1986. Iritium and Chlorine-36 Migration from a Nuclear Explosion Cavity. DOE/NV/10384-09, Publication 45050, Water Resources Center, Desert Research Institute, University of Nevada System, Las Vegas, Nevada.

For the Radionuclide Migration (RNM) Experiment, a 600-gpm pumping well has been placed approximately $288 \mathrm{ft}(90 \mathrm{~m})$ away from the center of the rubble chimney and cavity created by the 1965 Cambric event. The purpose of the experiment is to deliberately draw radionuclides away from the cavity and produce breakthrough curves of the migrating radionuclides at the pumping wel1. Tritium and ${ }^{36} \mathrm{C} 1$ are the most mobile radionuclides, and they hue Broduced bregkthrough curves that are amenable to analysis. Ruthenium-106, $85 \mathrm{Kr}$, and ${ }^{129} \mathrm{I}$ have also been observed at the pumping well in very small quantities.

For this study, a conceptual model of the Cambric cavity and the surrounding hydrogeologic environment has been formulated using available field data, such as core samples and the breakthrough curves of tritium and ${ }^{36} \mathrm{CT}$. The conceptual model was tested using a three-dimensional numerical 
code that solved the appropriate governing transport equations for flow and solute concentration. Based on the analysis of field data, longitudinal dispersivity, horizontal hydraulic conductixity and porosity of each layer, original masses and volumes of tritium and ${ }^{36} \mathrm{Cl}$, and pumping rates were held constant. Hydraulic conductivity of the cavity, ratio of horizontal to vertical hydraulic conductivity, transverse dispersivity, and retardation coefficients were varied for sensitivity analysis.

Results show that the hydraulic conductivity of the cavity is about one-tenth as large as the average hydraulic conductivity of the surrounding medium. To calibrate the model required retardation of the tritium. The amount of retardation needed is in agreement with recently published values. Although the breakthrough curve proved to be very sensitive to the choice of cavity hydraulic conductivity, the time of first arrival was not affected. The breakthrough curve was relatively insensitive to variations in the other parameters tested.

Coles, D.G., and L.D. Ramspott. 1982. "Migration of Ruthenium-106 in a NTS Aquifer: Discrepancy Between Field and Laboratory Results." Science 215:1235-1237.

Ruthenium-106 has been observed to migrate at about the same velocity as tritium in ground water from the site of an underground nuclear explosion to a pumped satellite well $298 \mathrm{ft}(91 \mathrm{~m})$ distant. This finding contradicts the prediction, based on laboratory batch-sorption measurements, that $106 \mathrm{Ru}$ should migrate at a much lower rate than tritium. To accurately predict migration of radionuclides in ground water, more relevant laboratory measurements are required.

Cooper, E.N., and M.A. Jones. 1982. Community Radiation Monitoring Program Annua] Report: Jan 1, 1981 - Nov 30, 1982. DOE/NV/10162-3, Desert Research Institute, University of Nevada System, Las Vegas, Nevada.

The primary purpose of the Community Radiation Monitoring Program is to augment the existing environmental monitoring network surrounding the NTS.

Crow, N.B. 1976. First Observations of Tritium in Ground Water Outside Chimneys of Underground Nuclear Explosions, Yucca Flat, Nevada Test Site. UCRL-52073, Lawrence Livermore National Laboratory, Livermore, California.

Abnormal levels of radionuclides had not been detected in ground water at the NTS beyond the immediate vicinity of underground nuclear explosions until Apri1 1974, when above-background levels of tritium activity were detected in ground water flowing from the tuff beneath Yucca Flat to an emplacement chamber being mined in hole U2aw in the east-central part of Area 2. No other radionuclides were detected in a sample of water from the chamber. In comparison with the amount of tritium estimated to be present in the ground water in nearby nuclear chimneys, the activity level at U2aw is very low. 
Daniels, W.R. 1978. Summary of RNM Actiyities During FY-78 (Dctober 1 , 1977 to September 30, 1978). Letter Report to R.W. Newman. Los Alamos Scientific Laboratory, Los Alamos, New Mexico.

This document briefly describes FY 1978 sampling for radionuclides at RNM-1 and RNM-2S, fieldwork at UE2ce and Ue49-2, and analyses of the data obtained. Publications relating to the RNM Project are listed, and the data are summarized in tables.

Daniels, W.R. 1979. Analyses of Core Samples From Ue4g-2. Letter Report, Los Alamos Scientific Laboratory, Los Alamos, New Mexico.

This letter report describes the resuits of analysis of sidewall core samples from exploratory hole $\mathrm{Je}_{4 \mathrm{~g}-2}$. Eight samples were analyzed. Relative amounts of ${ }^{106} \mathrm{Ru},{ }^{125} \mathrm{Sb}$, and ${ }^{13} \mathrm{Cs}$ present were determined and are presented in tables. Selected samples were first treated to recover water for tritium analysis and then dissolved for radiochemical analysis. Data for the tritium analyses and water content are presented in tables.

Daniels, W.R. 1979. Summary of RNM Activities During FY-79 (October 1. 1978 to September 30, 1979). Letter Report to R.W. Newman. Los Alamos Scientific laboratory, Los Alamos, New Mexico.

This document briefly describes FY 1979 sampling for radionuclides at RNM-2S and RNM-1, fieldwork at Ue2ce, and laboratory studies done in conjunction with the NNWSI program. Publications and presentations relating to the RNM Project are listed, and the data obtained by the studies are summarized in graphs and tables. The letter report also includes a copy of a November 9, 1979, memorandum by R.D. Aguilar and B.R. Erdal describing the analyses of bulk water sampies from RNM-2S.

Daniels, W.R., ed. 1981. Laboratory and Field Studies Related to the Radiation Migration Project: Dctober 1, 1979 - September 30, 1980. LA-8670-PR, Los Alamos National Laboratory, Los Alamos, New Mexico.

This progress report describes laboratory and field studies conducted during FY 1980 for the RNM Project, which was initiated in 1973 to study the movement of radionuclides from underground nuclear explosions at the NTS. Field results are presented from radiochemical analyses of water samples collected from the RNM-1 well and the RNM-2S satelljte wel1 at the Cambric site. Data are included for tritium, $85 \mathrm{Kr},{ }^{80} \mathrm{Sr}, 137 \mathrm{Cs}, 129 \mathrm{I}$, and what was tentatively identified as ${ }^{106} \mathrm{Ru}$. The maximum-concentration tritium peak at RNM-2S was estimated to be on August 1, 1981, with an uncertainty of 45 days. The report also discusses some of the extensive studies of the partition of various radionuclides between NTS tuff and ground water in conjunction with the NNWSI. Laboratory studies emphasized the sorptive behavior of tuff and its dependence on atmosphere, ground-water composition, and mineralogy. Results from batch measurements and crushed-rock and whole-core column studies are presented. 
Daniels, W.R. 1981. Laboratory Studies of Radionuclide Distributions Between Selected Groundwaters and Geologic Media: October 1, 1979 September 31, 1980. LA-8586-PR, Los Alamos National Laboratory, Los A1amos, New Mexico.

This annual report presents contributions to the Waste/Rock Interactions Technology program, Tasks 3 and 4, for FY 1980.

Daniels, W.R. 1981. Laboratory and Field Studies Related to the Radionuclide Migration Project: October 1, 1979 - September 30, 1980. LA-8670-PR, Los Alamos National Laboratory, LoS Alamos, New Mexico.

Laboratory and field studies related to the RNM project for FY 1980 are described. Results are presented for radiochemical analyses of water samples collected from the RNM-1 well and the RNM-2S satelljte well at the Cambric site. Data are included for tritium, $85_{\mathrm{Kr}}, 90_{\mathrm{Sr}}, 137_{\mathrm{Cs}}, 129_{\mathrm{I}}$, and what is tentatively identified as $106 \mathrm{Ru}$. Laboratory studies emphasize the sorptive behavior of tuff and its dependence on atmosphere, ground-water composition, and mineralogy. Results from batch measurements and from crushed-rock and whole-core column studies are presented.

Daniels, W.R. 1981. Laboratory Studies of Radionuclide Distributions Between Selected Groundwaters and Geologic Media: January 1 - March 31, 1981. LA-8818-PR, Los Alamos National Laboratory, Los Alamos, New Mexico.

This quarterly report presents contributions to the Waste/Rock Interactions Technology program, Tasks 3 and 4 , for the second quarter of FY 1981 .

Daniels, W.R. 1981. Laboratory Studies of Radionuciide Distributions Between Selected Groundwaters and Geologic Media: October 1 - December 31 , 1980. LA-8691-PR, Los Alamos National Laboratory, Los Alamos, New Mexico.

This quarterly report presents LANL contributions to the Waste/Rock Interactions Technology program, Tasks 3 and 4 , for the first quarter of FY 1981 .

Daniels, W.R., ed. 1982. Laboratory and Field Studies Related to the Radionuclide Migration Project: October 1, 1980 - September 30, 1981. LA-9192-PR, Los ATamos National Laboratory, Los Alamos, New Mexico.

This progress report describes laboratory and field studies conducted during FY 1981 for the RNM Project, which was initiated in 1973 to. study the movement of radionuclides produced from underground nuclear explosions at the NTS. Field results include radiochemical analyses of water samples collected from the RNM-I well and the RNM-2S satellite well at the Cambric site. Data are included for tritium, $85 \mathrm{Kr},{ }^{129} \mathrm{I}$, and ${ }^{36} \mathrm{CT}$. The maximum-concentration tritium peak arrived at RNM-2S near the end of FY 1981. The report discusses studies done in conjunction with the NNWSI concerning the partition of various radionuclides between NTS tuff and ground water. Laboratory studies 
emphasize the sorption behavior of alluvium and tuff and its dependence on mineralogy. Results from batch measurements and crushed-rock and whole-core column studies are presented.

Daniels, W.R., ed. 1983. Laboratory and Field Studies Related to the Radionuclide Migration Project: 0ctober 1, 1981 - September 30, 1982. LA-9691-PR, Los Alamos National Laboratory, Los Alamos, New Mexico.

This progress report describes laboratory and field studies conducted during FY 1982 for the RNM Project. Results are presented for radiochemical analyses of water samples collected from the RNM-1 well and the RNM-2S satellite we]l at the Cambric site. Data are included for tritium, ${ }^{36} \mathrm{Cl}$, ${ }^{85} \mathrm{Kr},{ }^{9} \mathrm{Sr},{ }^{2}{ }^{2} \mathrm{I}$, and ${ }^{13} \mathrm{C}_{\mathrm{S}}$. Laboratory studies emphasize the sorptive behavior of tuff and its dependence on mineralogy.

Daniels, R.W., and J.L. Thompson, eds. 1984. Laboratory and Field Studies Related to the Radionuclides Migration Project: 0ctober 1, 1982 September 30, 1983. LA-10121-PR, Los Alamos National Laboratory, Los Alamos, New Mexico.

This progress report describes laboratory and field studies conducted during FY 1983 for the RNM Project, which was initiated in 1973 to study the movement of radionuclides at the NTS. Results are presented for radionuclide analyses of water samples collected from the RNM-1 well and the RNM-2S satelljte well at the Cambric site. Data are included for tritium, ${ }^{36} \mathrm{Cl}$, $85 \mathrm{Kr},{ }^{90} \mathrm{Sr},{ }^{129} \mathrm{I}$, and ${ }^{13} \mathrm{Cs}$. Preliminary results from water collected at the Cheshire site are reported. Laboratory studies emphasize the sorptive behavior of tuff and its dependence on mineralogy.

Daniels, W.R., and K. Wolfsberg. 1981. Laboratory Studies of Radionuclide Distributions Between Selected Groundwaters and Geologic Media: April l June 31, 19B1. LA-8952-PR, Los A1 amos National Laboratory, Los A1 amos, New Mexico.

This quarterly report presents contributions to the Waste/Rock Interaction Technology program, Tasks 3 and 4, for the third quarter of FY 1981.

Elliott, B. 1982. An Investigation of Selected Water Quality Parameters in the Amarqosa Drainage Basin. D0E/NV/10162-18, Water Resources Center, Desert Research Institute, University of Nevada System, Las Vegas, Nevada.

The DRI investigated certain parameters of drinking water quality in the Amargosa Desert, Nevada and California, to determine whether the water quality met established Federal drinking water standards. The area of interest is located west and south of the NTS. It contains flow paths and discharge locations of ground waters draining the NTS. Samples were collected at selected drinking water supply sites and were analyzed for inorganic chemical constituents and radioactivity. The findings indicate that no concentrations of radioactivity in the water exceeded drinking water standards; however, some of analyses indicated naturally occurring chemical constituent concentrations above Federal drinking water standards. 
French, R.H., and J.W. Hess. 1985. Radionuclide Transport by Surface Water: Preliminary Studies in Fortymile Canyon. DOE/NV/10384-06, Publication 45047, Water Resources Center, Desert Research Inst itute, University of Nevada System, Las Vegas, Nevada.

Precipitation and resulting overland flow at the NTS could be an important hydrologic mechanism by which radionuclides are collected, concentrated, and transported. The report discusses the progress made on the study of radionuclide transport by surface water, which was authorized in FY 1983. The report addresses a number of specific topics: The criteria for the selection of a field study area are reviewed, and the field study area selected - a reach of Fortymile Canyon below the Buggy event - is discussed. The sampling and analys is program conducted through FY 1985 is described. The continuing precipitation monitoring program in support of this project and its results to date are discussed. Finally, the watershed/radionuclide transport model tentatively selected for use in this project is discussed.

Fried, S., ed. 1979. "A Field Study of Radionuclide Migration." In Radioactive Waste in Geologic Storage. ACS Symposium Series No. 100, pp. 149-166. American Chemical Society, Washington, D.C.

This article discusses the radionuclide distribution in both water and aggregate around a $0.75-k i l o t o n$ nuclear test that was detonated at the NTS. The explosion cavity was re-entered in 1974 for studies of the distribution of radionuclides as part of the RNM Project. Sidewall core samples were obtained from near the surface to below the original cavity region. Representative water samples were pumped from five zones in the cavity and rubble regions. Most of the radioactivity found was in solid material contained in the lower cavity region. Water pymped from the region of highest radioactivity showed only tritium and ${ }^{90} \mathrm{Sr}$ to be at levels higher than the recommended concentration guides for drinking water.

Fritzsche, A.E., H.W Clark, and E.L. Feimster. 1979. An Area Radiological Survey of Areas 1, 2, 3, 4, 6, 7, 8, 9, 10, 11, 12, 13, 15, 17, 18, 20, 25, and 26, of Yucca Flat, Nevada Test Site, Nevada. EGG-1183-1808 (1982), EGG-10282-1004 (1983), EGG-1183-1752(1979), EGG-1082-1093 (1985), EGG-1183-1745, The Remote Sensing Laboratory, Las Vegas, Nevada.

The Aerial Measuring System was used to radiometrically survey most of Yucca Flat at the NTS. Subsequent to the aerial survey and interpretation of the aerial data, soil samples were gathered at numerous locations at areas of human activity.

Hansen, D.S. 1978. Iritium Movement in the Unsaturated Zone, Nevada Test Site. University of Nevada, Reno, Nevada.

Tritium movement in three different geomorphic settings was investigated at the NTS. Two hundred soil samples were collected from high-fan, mid-fan, and playa sediments in Yucca and Frenchman Flats. Tritium activities for surface sediments on Yucca Flat ranged from 250 to 900 Tritium Units (T.U.), with higher values 1 imited to mid-fan sediments. At 0.5 and $1.0 \mathrm{ft}(0.15$ and 
$0.3 \mathrm{~m}$ ), activities dropped to 100 to $200 \mathrm{~T} . \mathrm{U}$. in all Yucca Flat sediments. Surface activities on Frenchman Flat ranged from background (80-100 T.U.) to 550 T.U., with higher values limited to playa sediments. Background levels were observed at 2 to $3 \mathrm{ft}(0.6$ to $0.9 \mathrm{~m})$ in mid-fan and playa sediments and were not observed in high-fan sediments because sample depth were limited to $2 \mathrm{ft}(0.6 \mathrm{~m})$. Infiitration tests were conducted with water containing 1000 to 2000 T.U. Data suggest that tritium infiltrated 1.0 to $2.0 \mathrm{ft}(0.3$ to $0.6 \mathrm{~m})$ in playa, more than $4 \mathrm{ft}(1.2 \mathrm{~m})$ in mid-fan, and more than $2.5 \mathrm{ft}$ $(0.76 \mathrm{~m})$ in high-fan sediments in Yucca Flat. Activities in surface sediments on Frenchman Flat infiltration sites show similar pre-infiltration values and large post-infiltration increases to $1000 \mathrm{~T} . \mathrm{U}$. at 1.0 to $1.5 \mathrm{ft}$ (0.3 to $0.46 \mathrm{~m}$ ) in all settings, probably due to $1 \mathrm{in} .(2.5 \mathrm{~cm})$ of rain one week prior to sampling. Caliche was observed at 1.5 to $2.5 \mathrm{ft}(0.46$ to $0.76 \mathrm{~m}$ ) in all mid-fan sediments, perhaps preventing deeper penetration of soil moisture and tritium.

Hoffman, D.C. 1977. Analysis of Dirt from U4g. Letter Report to Richard Henderson. Los Alamos National Laboratory, Los Alamos, New Mexico.

This one-page letter describes analysis of a sample of dirt from U4g that was selected because gamma actjuity was detected Gamma-spectral analysis of this material showed ${ }^{106} \mathrm{Ru},{ }^{125} \mathrm{Sb}$, and ${ }^{137} \mathrm{Cs}$ were present. The atomic ratios indicate that the nuclides were produced in approximately 1972.

Hoffman, D.C. 1977. Summary of RNM Activities During FY-76T and FY-77 (July 1, 1976 to September 30, 1977). Letter Report to R.W. Newman. Los Alamos Scientific Laboratory, Los Alamos, New Mexico.

This four-page ietter report describes work conducted for the RNM Project from July 1976 through September 1977. Pumping water from RNM-2S stopped in August. Tritium analyses were performed on the water, with the results very close to background. Water pumped from UE2ce showed a exponential increase in tritium, which leveled off at a value of about $4 \mathrm{nCi} / \mathrm{ml}$. A core and water sampling program similar to that conducted at RNM-1 (Cambric) Site was proposed for U2On, which was the site of a nuclear test in a rhyolitic medium. Laboratory tests include leaching debris from nuclear tests with ground water from the same areas, to determine the leachability of various radionuclides. However, the results of these analyses are not discussed.

Hoffman, D.C., and W.R. Daniels. 1981. Assessment of the Potential for Radionuclide Migration from a Nuclear Explosion Cavity. Preprint LA-UR-81-3181, Los Alamos National Laboratory, Los Alamos, New Mexico.

This paper gives an assessment of the potential for radionuclide movement from the sites of underground nuclear explosions at the NTS. The study began about nine years after detonation of the nuclear test. The results indicate that during nearly six years of pumping from a satellite well located $298 \mathrm{ft}(91 \mathrm{~m})$ from the Cambric cavity, only tritium and $85 \mathrm{Kr}$ have been positively identified in water removed from the well. These results are consistent with laboratory studies that indicate that radionuclide sorption 
is high enough to preclude the migration of such nuclides from the original cavity to the satellite well in the near future. Pumping and radioassay of water from the satellite well to investigate the possible arrival of nonsorbing species were continuing.

Hoffman, D.C., R. Stone, and W.W. Dudley. 1977. Radioactivity in the Underground Environment of the Cambric Nuclear Explosion at the Nevada Test Site. LA-6877-MS, Los Alamos National Laboratory, Los Alamos, New Mexico.

This informal report discusses resuits of investigations of radionuclide movement from the Cambric Site at the NTS, as part of the RNM Project. Ten years after a $0.75-k i l o t o n$ nuclear test was fired $984 \mathrm{ft}(300 \mathrm{~m})$ underground in alluvium, most of the radioactivity was still contained within solid material in the lower cavity region. Water pumped from the region of highest activity at the bottom of the cavity showed only tritium and ${ }^{90} \mathrm{Sr}$ to be at levels higher than the recommended concentration guides for drinking water in uncontrolled areas. Recommendations for future studies are given.

Hoffman, D.C., W.R. Daniels, K. Wolfsberg, J.I. Thompson, R.S. Rundberg, S.L. Fraser, and K.S. Daniels. 1983. A Review of a Field Study of Radionuclide Migration From an Underground Nuclear Explosion at the Nevada Test Site. LA-UR-83-493, Los Alamos National Laboratory, Los ATamos, New Mexico.

This review summarizes results from nine years of the RNM Project, which was initiated in 1974 to study the movement of radionuclides from underground nuclear explosions at the NTS. Initial studies were conducted near the site of the low-yield Cambric test, which was detonated $239 \mathrm{ft}$ (73 m) beneath the water table in tuffaceous alluvium. Solid samples were obtained from just below ground surface to $164 \mathrm{ft}(50 \mathrm{~m})$ below the detonation point, and water was sampled from five zones in the vicinity of the explosion. Ten years after the test, most of the radioactivity was found to be retained in the fused debris in the cavity region, and no activity above background levels was found $164 \mathrm{ft}(50 \mathrm{~m})$ below. Only tritium and ${ }^{90} \mathrm{Sr}$ were present in water in the cavity at levels greater than recommended concentration guides for water in uncontrolled areas.

Isherwood, D., H. Harrar, and E. Raber. 1982. Characterization of Climax Granite Ground Water. UCRL-53309, Lawrence Livermore National Laboratory, Livermore, California.

The Climax ground water fails to fit the commonly held views regarding the nature of deep granitic ground waters: it is neither dilute nor in equilibrium with the granite. Ground-water samples were taken for chemical analysis from five sites in the fractured Climax granite at the NTS. The waters are high in total dissolved solids and rich in sodium, calcium, and sulfate. Two of the samples contained relatively high amounts of uranium; the other three contained uranium below the level of detection. The pH was in the neutral range. 
Kahn, M., and J. Kleinberg. 1977. Radiochemistry of Iodine. Prepared for Subcommittee on Radiochemistry, National Academy of Sciences-National Research Council. NAS-NS-3062, National Academy of Sciences, Washington, D.C.

This report is a comprehensive treatise on the radiochemistry of iodine.

Ogard, A.E., J.L. Thompson, R.S. Rundberg, K. Wolfsberg, P.W. Kubik, D. Elmore, and H.W. Bentley. 1988. Migration of Chlorine-36 and Tritium from an Underground Nuclear Test." Radiochimica Acta 44(45):213-217.

This article describes a field experiment to study the migration of radioactive elements through alluvium away from an underground nuclear explosion at the NTS. Tritium and ${ }^{36} \mathrm{Cl}$ were detected in pumped water at levels below the maximum permissible concentration for drinking water in controlled areas. Conventional modeling of these results was unsatisfactory; successful modeling of this experiment will be important for validating codes and models to be used in the high-level nuclear waste program.

Oswald, K.M. 1971. Report of Information Pertinent to U9ITS-U-29. Subject Report, KMO-17-71, Lawrence Livermore Laboratory, Livermore, Cal ifornia.

This report presents information about the detection, recovery, and analysis of contamination in the U-29 emplacement hole on February 8, 1971. No attempt is made to draw any conclusions from the information presented. The contamination was confined to grease and dried drilling mud on the drilling rig. The report indicated that a reasonable explanation for the presence of the radioactivity was the migration of radioactive materials along subsurface fractures.

Sauty, J.P. 1980. "An Analysis of Hydrodispersive Transfer in Aquifers." Water Resources Research 16(1):145-158.

This work is concerned with the nonreactive transport of solute materials in ground water, or hydrodispersive transfer. Several types of flow fields are considered: Tinear flow with one- and two-dimensional dispersion and radial flow under diverging and converging conditions. The analysis includes the two main possibilities for introduction of solutes into an aquifer: continuous and instantaneous injection. An analysis of the errors committed in some commoniy used approximations for dispersion as a function of the Peclet number is also reported.

Thompson, J.L., ed. 1985. Laboratory and Field Studies Related to the Radionuclide Mioration. Project: October 1, 1983 - September 30, 1984. LA-10372-PR, Los Alamos National Laboratory, Los Alamos, New Mexico.

This progress report describes laboratory and field studies conducted during FY 1984 for the RNM Project. The report discysses the continued field monitoring of the migration of tritium, $85 \mathrm{kr}$, and $129 \mathrm{I}$ from the Cambric cavity region to the pumped satellite well RNM-2S. Analys is of the fieid data indicates that no radioactive cations have appeared in the RNM-2S water. 
Concentrations of lithium, tritium, and a number of fission products and other radioactive elements were measured at two depths at the Cheshire site. Analyses of these data indicate that the concentrations at the Cheshire site are anomalously low, and the interpretation of data from the Cheshire site is somewhat uncertain. The data indicate that retention of radionuclides by the rhyolite of Pahute Mesa is comparable to that by the alluvium of Frenchman Flat. The report summarizes continuing studies of sorption phenomena, chemical speciation, and colloid behavior. Laboratory work resulted in improved capabilities for gamma spectroscopy and mass spectrometry. Progress on chemical equilibria and colloid transport is also discussed.

Thompson, J.L., ed. 1986. Laboratory and Field Studies Related to the Radionuclide Migration Project: October 1, 1984-September 30, 1985. LA-10644-PR, Los Alamos National Laboratory, Los Alamos, New Mexico.

This progress report describes laboratory and field studies conducted during FY 1985 for the RNM Project, which was initiated in 1973 to study the movement of radionuclides at the NTS. Monitoring results for the satellite well at the Cambric site show the continuing elution of tritium and $85 \mathrm{Kr}$ from the cavity but no appearance of fission-product cations. Water samples taken from two depths in the re-entry hole at Cheshire demonstrate similar concentrations of radionuclides. This result, along with anomalously low tritium concentrations, makes the interpretation of data from Cheshire somewhat uncertain. The report summarizes progress made in laboratory studies of radionuclide sorption, actinide speciation, and colloid detection and migration.

Thompson, J.L., ed. 1987. Laboratory and Field Studies Related to the Radionuclide Migration Project: October 1, 1985 - September 30, 1986. LA-11081-PR, Los Alamos National Laboratory, Los ATamos, New Mexico.

This progress report describes work conducted during FY 1986 for the RNM Project, which was initiated in 1973 to study the movement of radionuclides at the NTS. Monitoring results for tritium and $85 \mathrm{Kr}$ transport from the Cambric explosion zone to the satellite well are described. Data from the Cheshire site are analyzed, but these data do not resolve the uncertainties about the distribution and movement of radionuclides. Improved analytical capabilities for detecting ${ }^{36} \mathrm{Cl}$ and ${ }^{99} \mathrm{Tc}$, as well as the increased understanding of radionuclide transport phenomena, are discussed. An exchange of samples with Lawrence Livermore National Laboratory indicated critical steps in procedures for collecting and analyzing large-volume water samples. In addition, analyses of potential sites on the Pahute Mesa for future radionuclide migration studies indicate that the present cheshire site is the only site available for migration studies, now and for the near future. 
Thompson, J.L., ed. 1988. Laboratory and Field Studies Related to the Radionuclide Migration Project: October 1, 1986 - September 30, 1987. LA-I1223-PR, Los ATamos National Laboratory, LoS Alamos, New Mexico.

This report describes research conducted during FY 1987 for the RNM Project, which was initiated in 1973 to study the movement of radionuclides at the NTS. The field data discussed in the report relate to the 1) elution of tritium, krypton, and ${ }^{36} \mathrm{Cl}$ from well $\mathrm{RNM}-2 \mathrm{~S}$ at the Cambric site, 2) detection of tritium and fission products in a water sample from hole UE20n\#l at the Cheshire site, and 3) movement of radionuclides at the Aleman site. These data were used in other research to test the validity of several models of solute transport through geologic media. The laboratory work discussed includes 1) a characterization of the size and density of two stable plutonium (IV) colloid suspensions prepared by different techniques and 2) a study of the transmission of colloidal-size polystyrene beads through crushed-rock columns.

Thompson, J.L., ed. 1989. Laboratory and Field Studies Related to the Hydrology/Radionuclide Migration Project: October 1,1987 -

September 30, 1988. LA-11595-PR, Los A1 amos Nationa7 Laboratory, Los A1 amos, New Mexico.

This report describes field and laboratory research conducted during FY 1988 for the Hydrology/Radionuclide Migration Project (formally the Radionuclide Migration Project), which was initiated in 1973 to study the movement of radionuclides at the NTS. The elution of tritium, $85 \mathrm{Kr}$, and fission products continued to be monitored from well RNM-2S at the Cambric site. Analysis of field data indicated that about $85 \%$ of the tritium had eluted from this well, but no radionuclides were present in the eluate. The concentrations of tritium, $85 \mathrm{Kr}$, and $125 \mathrm{Sb}$ in sampies from the UE20n\#1 hole at the cheshire site were approximately the same as in the U20n hole, but the concentration of 137 Cs was appreciably lower. The presence of hydrous ferric oxides in the UE20n\#1 water made sample analyses difficult to interpret. Laboratory studies of the size/density properties of plutonium (IV) colloids continued with the completion of a clean-room facility. This report also contains a proposed plan for future work at Yucca Flat.

Thordarson, W. Hydrologic Monitoring at the Faultless Site. Nye County, Nevada. Water Resources Investigations Report 84-XXX, U.S. Geological Survey, Denver, Colorado.

The Faultless event was the detonation of an intermediate-yield nuclear device on January 19, 1968, at a depth of 3,198 ft (975 m) below the surface of Hot Creek Valley, Nevada. This report presents details of the hydrogeology and radiochemical monitoring, predominantly from reentry hole UC-1-P-2SR, although data from other holes are also included. 
Winograd, I.J., and F.J. Pearson, Jr. 1976. "Major Carbon-14 Anomaly in a Regional Carbonate Aquifer: Possible Evidence for Megascale Channeling, South Centra] Great Basin." Water Resources Research 12(6).

The ${ }^{14} \mathrm{C}$ content of ground water at the center of a $10-\mathrm{mi}-(16-\mathrm{km}) 1 \mathrm{ong}$ fault-controlled spring line at Ash Meadows in south central Nevada is five times greater than that in water from other major springs along the lineament. The difference in ${ }^{14} \mathrm{C}$ stands in marked contrast to the near identity among all springwaters in alkalinity, $\mathrm{pH},{ }^{13} \mathrm{C}, 18_{0}$, deuterium, tritium, and other major and trace ions.

\section{Sorption and Leaching Studies}

Coles, D.G. 1981. "A Continuous-Flow Leach Testing Method for Various Nuclear Waste Forms." Nuclear and Chemical Waste Management 2:245-252.

An in vitro single-pass continuous-flow leaching test was run, with leachants ranging from saturated salt brine to distilled water. Temperatures varied from 77 to $167^{\circ} \mathrm{F}\left(25\right.$ to $\left.75^{\circ} \mathrm{C}\right)$. The testing methodology is discussed, as well as examples of data obtained from leaching a variety of waste forms under various conditions.

Coles, D.G., H.C. Weed, D.D. Jackson, and J.S. Schweiger. 1978. SinglePass Leaching of Nuclear Melt Glass by Groundwater, Part I. Lawrence Livermore National Laboratory, Livermore, California.

Meit glass produced by three underground nuclear explosions was leached at $77^{\circ} \mathrm{F}\left(25^{\circ} \mathrm{C}\right)$ with ground water obtained from a well near the explosion sites. Leaching was carried out in cells, with the ground water passing over glass particles at flow rates of 14 and $2.6 \mathrm{in.} / \mathrm{d}(36$ and $6.7 \mathrm{~cm} / \mathrm{d})$. With this dynamic flow-through system, the solid sample is continually exposed to fresh leaching solution in an attempt to simulate actual underground conditions. Radionuclide concentrations in the leachate were obtained $1,2,3,4$, $11,32,38,70$, and 120 days after the leaching began. The fraction of radioactivity leached per day per square meter of surface area varied from $1.5 \times 10^{-2}$ for $22 \mathrm{Na}$ on day 1 to $7.0 \times 10^{-6}$ for $144 \mathrm{Ce}$ on day 120 . Except for that of ${ }^{144} \mathrm{Ce}$, leaching rates did not seem to depend significantly on flow rates.

Daniels, W.R., et a 1. 1982. Summary Report on the Geochemistry of Yucca Mountain and Environs. LA-9328-MS, Los Alamos National Laboratory, Los Alamos, New Mexico.

This report describes technical efforts conducted from FY 1977 unt $i 1$ March 1982 to resolve geochemistry issues pertinent to siting a nuclear-waste repository in tuff at the NTS. Tuff provides the first natural barrier to the migration of waste elements from a repository; therefore, the properties and setting of tuff were investigated, with particular emphasis on retardation processes. This report addresses sorption by tuff, the physical and chemical makeup of tuff, diffusion processes, tuff/ground-water chemistry, 
waste-element chemistry under expected repository conditions, transport processes involved in porous and fracture flow, and geochemical and transport modeling.

Erda1, B.R. 1979. Laboratory Studies of Radionuclide Distributions Between Selected Ground Waters and Geologic Media: October 1-Oecember 31, 1978 . LA-7638-PR, Los Alamos National Laboratory, Los Alamos, New Mexico.

Studies for the first quarter of FY 1979 mostly involved uranium, plutonium, and americium batch sorption studies needed to extend or complete the data bases for argillite, tuff, and granite. Initial efforts have been made to develop the equipment and procedures for performing migration-rate studies on crushed, consolidated, and fractured rock, and for performing measurements under controlled atmosphere conditions. Several additional analytical procedures for chemical characterization have been developed, and several additional ethylene glycol surface-area measurements have been completed.

Erda1, B.R. 1979. Laboratory Studies of Radionuclide Distributions Between Selected Groundwaters and Geologic Media: January 1 - March 31, 1979. LA-7780-PR, Los Alamos National Laboratory, Los Alamos, New Mexico.

This report discusses plutonium, americium, and uranium batch sorption studies on argillite. The behavior of plutonium and americium in aqueous solutions at pH 8 with respect to container sorption, filtering, and centrifuging was also investigated. Studies of the variability of the sorption behavior for tuff were completed. Migration rate studies on crushed and fractured materials were initiated. Systems for performing controlled atmosphere measurements have been completed. Additional chemical analyses have been performed, as were some studies related to microautoradiography. Additional cation exchange capacity and ethylene surface area measurements have also been made.

Erda7, B.R. 1979. Laboratory Studies of Radionuclide Distributions Between Selected Groundwaters and Geologic Media: April l - June 30, 1979.

LA-7893-PR, Los Alamos National Laboratory, Los Alamos, New Mexico.

Plutonium, americium, and uranium batch sorption studies are described. The technetium sorption ratio on tuff was not found to be dependent on technetium concentration. Studies of the behavior of plutonium and americium in aqueous solutions at $\mathrm{pH} 8$ were continued. Studies of the sorption of strontium, cesium, barium, cerium, europium, uranium, and americium on salt-dome materials were made under atmospheric and controlled-atmosphere conditions. The first experiments to assess the dependence of sorption ratio on groundwater composition were started. Migration rate studies using crushed-rock columns and fractured cores were continued. Additional chemical analyses were conducted, as were some studies of the sorption of plutonium and neptunium using a microautoradiographic technique. 
Erda1, B.R. 1980. Laboratory Studies of Radionuclide Distributions Between Selected Groundwaters and Geologic Media: October 1, 1978 - September 30, 1979. LA-8088-PR, Los Alamos National Laboratory, Los Alamos, New Mexico.

Extensive studies of the behavior of plutonium and americium in $\mathrm{pH} 8$ ground waters were made, particularly with respect to container sorption, filtering, and centrifugation. The method used for measuring sorption ratios for these elements was significantly improved and the sorption-desorption ratios on argillite and tuff were measured. Effects on particle size, temperature, sampling location, mineralogy, and time were investigated for these elements. The chemical composition of the water was found to be a major factor governing sorption behavior.

Erdal, B.R. 1980. Laboratory Studies of Radionuclide Distributions Between Selected Groundwaters and Geologic Media: October 1 - December 31, 1979. LA-8210-PR, Los Alamos National Laboratory, Los Alamos, New Mexico.

The majority of the effort involved extensive studies under reduced oxygen and carbon dioxide conditions, measurements of jsotherms, microautoradiographic studies, and migration rate studies. Efforts to estimate uranium, plutonium, and neptunium solubilities were initiated.

Erdal, B.R. 1980. Laboratory Studies of Radionuclide Distributions Between Selected Groundwaters and Geologic Media: January 1 - March 31, 1980. LA-8339-PR, Los Alamos National Laboratory, Los ATamos, New Mexico.

This report presents contributions to the Waste/Rock Interactions Technology program, Tasks 3 and 4, for the second quarter of FY 1980.

Erda1, B.R. 1980. Laboratory Studies of Radionuclide Distributions Between Selected Groundwaters and Geojogic Media: April 1 - June 30, 1980. LA-8472-PR, Los Alamos National Laboratory, Los Alamos, New Mexico.

This quarterly report presents contributions to the Waste/Rock Interactions Technology program, Tasks $3 \& 4$, for the third quarter of FY 1980.

Erdal, B.R., W.R. Daniels, D.C. Hoffman, F.0. Lawrence, and K. Wolfsberg. 1978. Sorption and Migration of Radionuclides in Geologic Media. LA-UR-78-2746, Los Aīamos National Laboratory, Los Alamos, New Mexico.

The interactions of a quartz monzonite, argillite, alluvium, and several tuffs with various radionuclides in selected phreatic waters were studied. The adsorption-desorption behavior of $\mathrm{Sr}, \mathrm{Tc}$ (VII), Cs, Ba, Ce, Eu, $U(V I), P u$, and Am under ambient and $158^{\circ} \mathrm{F}\left(70^{\circ} \mathrm{C}\right)$ temperature conditions were measured.

Erdal, B.R., R.D. Aguilar, B.P. Bayhurst, P.Q. 01iver, and K. Wolfsberg. 1979. Sorption-Desorption Studies on Arqillite: I. Initial Studies of Strontium, Technetium, Cesium, Barium, Cerium, and Europium. LA-7455-MS, Los Alamos National Laboratory, Los Alamos, New Mexico. 
Distribution ratios were determined for adsorption-desorption of radioactive tracers between Eleana argillite available from the NTS and a water prepared to be representative of the natural ground-water composition. The measurements were performed at 71.6 and $15.8 \circ \mathrm{F}\left(22\right.$ and $\left.70^{\circ} \mathrm{C}\right)$ under atmospheric oxygen conditions. The effects of surface area and mineralogy were also investigated.

Erdal, B.R., et al. 1979. Sorption-Desorption Studies on Granite: I. Initial Studies of Strontium, Technetium, Cesium, Barium, Cerium. Europium, Uranium, Plutonium, and Americium. LA-7456-MS, Los ATamos National Laboratory, Los Alamos, New Mexico.

Distribution ratios were determined for adsorption-desorption of radioactive tracers between the Climax Stock granite obtained at the NTS and a water prepared to be reasonably representative of the natural composition of water in equilibrium with the Climax Stock granite. The measurements were performed at 71.6 and $158^{\circ} \mathrm{F}\left(22\right.$ and $\left.70^{\circ} \mathrm{C}\right)$ under atmospheric oxygen conditions. The effects of surface area and mineralogy on sorption were also investigated.

Failor, R.A., D.G. Coles, and J.H. Rego. 1983. A Leaching Study of Nuclear Melt Glass: Part I. UCID-19729, Lawrence Livermore National Laboratory, Livermore, California.

Ground samples of three nuclear melt glasses from underground explosions at the NTS were leached at $77^{\circ} \mathrm{F}\left(25^{\circ} \mathrm{C}\right)$ with natural ground water from the NTS. Using a dynamic single-pass flow-through leaching system, the release of radionuclides from the glasses was monitored during 4,209 days of leaching. The ground water flowed over the melt glass continually at flow rates of $185 \mathrm{ml} /$ day for half of the samples and $34 \mathrm{ml} /$ day for the rest. Leachate solutions were collected continuously, and composite samples were analyzed using Tow-background $\mathrm{Ge}(\mathrm{L} i)$ gamma spectrometers.

Kautsky, M. 1984. Sorption of Cesjum and Strontium by Arid Region Desert Soil. Publication 45037, Water Resources Center, Desert Research Institute, University of Nevada System, Las Vegas, Nevada.

Adsorption and ion exchange in soil systems are the principal mechanisms that slow the migration of nuclear waste to the biosphere. The radioactive isotopes ${ }^{13} \mathrm{Cs}$ and ${ }^{90} \mathrm{Sr}$ are commonly disposed of as nuclear waste. To obtain background information, the sorption and ion-exchange properties of nonradioactive cesium and strontium were studied. The soil used in this study was collected at an experimental infiltration site on Frenchman Flat, a closed drainage basin on the NTS. The soil was mostly nonsaline-alkali sandy loam and loamy sand, with a cation exchange capacity ranging from 13 to $30 \mathrm{me} / 100 \mathrm{~g}$. The clay fraction of the soil contained illite, montmorillonite, and clinoptilolite. The ion-exchange studies show that this soil sorbs cesium preferentially over strontium and that, charge for charge, the exchange-phase cations released from exchange sites exceed the cesium and strontium sorbed by the soil. 
MacLean, S.C., D.G. Coles, and H.C. Weed. 1978. The Measurement of Sorption Ratios for Selected Radionuclides on Various Geologic Media. UCID-17928, Lawrence Livermore Nationa] Laboratory, Livermore, California.

Experiments were conducted to determine the sorptive characteristics of a variety of rocks and minerals with respect to several radionuclides of interest. The purpose of this information was to be used in determining rates of radionuclide migration from nuclear-waste repositories. This document gives the results of batch $R_{d}$ experiments, and details of the laboratory procedure are described.

Ramspott, L.D., J.D. Tewhey, D.G. Coles, H.C. Weed, J.S. Schweiger, and R. Stone. 1979. EY78 Annual Technical Report of Lawrence Livermore Laboratory's Participation in the DOE-NV Project: Radionuclide Migration in the Ground. UCID-18259-78, Lawrence Livermore National Laboratory, Livermore, California.

Activities reported include 1) laboratory study of single-pass leaching of nuclear melt glass by NTS ground water, 2) design of field and laboratory distillation apparatus to concentrate water samples to make low levels of radionuclides detectable, 3) feasibility studies for in situ tracer studies at the NTS, 4) periodic sampling and analysis of water from sites of nuclear tests, and 5) geochemical studies of melt glass from underground nuclear tests.

Thomas, K.W. 1987. Summary of Sorption Measurements Performed with Yucca Mountain. Nevada, Tuff Samples and Water from Well J-13. LA-10960-MS, Los Alamos National Laboratory, Los Alamos, New Mexico.

This report describes sorption studies conducted from 1977 to 1985 in support of the NNWSI to help determine the suitability of the Yucca Mountain tuffs as a permanent geologic repository for high-level nuclear waste. The purpose of the sorption studies is to quantify the contribution of sorption processes toward reducing the transport of radionuclides from the repository to the accessible environment. (Sorption can delay or retard the movement of radionuclides relative to water flow; therefore, the sorption process has a direct affect on whether the Yucca Mountain environment meets the release limits specified by the EPA and the NRC.) Sorption is investigated as a function of mineralogy, temperature, particle size, waste-element concentration, water composition, sorption time, and other variables. Most of the report is an appendix with batch sorption ratios for tuffs of the Yucca Mountain area and wel1 j-13 water.

Treher, E.N., and N.A. Raybold. 1982. The Elution of Radionuclides through Columns of Crushed Rock from the Nevada Test Site. LA-9329-MS, Los Al amos National Laboratory, Los Alamos, New Mexico.

Results from the elution of radionuclides through columns of crushed tuff, granite, and argillite are presented. Good agreement between column and batch measurements on washed samples is generaliy observed for all three rock types. This is encouraging, because the results of batch measurements 
are often of value to show relative sorption under a variety of conditions, and their relevance to the migration of radionuclides under flowing conditions has been questioned.

Vine, E.N., et a1. 1980. Sorption-Desorption Studies on Tuff: II. A Continuation of Studies with Samples from Jackass Flats, Nevada, and Initial Studies with Samples from Yucca Mountain, Nevada. LA-8110-MS, Los Alamos National Laboratory, Los A1 amos, New Mexico.

Distribution coefficients were determined by a static technique for adsorption-desorption of radionulides between tuffs from dri门l holes UE25a-1 and $\mathrm{J}-13$ and water from we11 $\mathrm{J}-13$. Measurements were performed under both atmospheric and controlled-atmosphere conditions. Under atmospheric conditions, tuffs high in zeolite minerals had sorption ratios of $10^{3}$ to $10^{4} \mathrm{ml} / \mathrm{g}$ with $\mathrm{Sr}, \mathrm{Cs}, \mathrm{Ba}, \mathrm{Ce}, \mathrm{Eu}, \mathrm{Am}$, and $\mathrm{Pu}$. For tuffs that were mineralogicaliy similar to a microgranite, the sorption ratios were $10^{2}$ to $10^{3} \mathrm{ml} / \mathrm{g}$. Values for $U$ and TC were obtained under controlled-atmosphere conditions. Other studies were begun to measure distribution ratios by a dynamic technique. The ratios obtained for $\mathrm{Sr}, \mathrm{Cs}$, and $\mathrm{Ba}$ were similar to, although Tower than, those obtained by batch methods.

Weed, H.C., and D.D. Jackson. 1979. Design of a Variable-Flow-Rate, Single-Pass Leaching 5ystem. UCRL-52785, Lawrence Livermore National Laboratory, Livermore, California.

This report describes designs of leaching systems for experiments on several kinds of solids, including glassy debris from underground nuclear explosions at the NTS, refractory compositions for retention of radioactive nuclear-reactor waste, and spent reactor fuel. The system used on puddle glass has a continuously variable flow rate from 0.79 to $28 \mathrm{in.} 3 / \mathrm{d}$ (13 to $\left.460 \mathrm{~cm}^{3} / \mathrm{d}\right)$, a temperature range from 77 to $167^{\circ} \mathrm{F}\left(25\right.$ to $\left.75^{\circ} \mathrm{C}\right)$, operating capacity for up to 20 simultaneous experiments, and one-pass operation with continuous exposure of samples to fresh solution. Results obtained on puddle glass are in qualitative agreement with those on siljcate glasses designed for isolation of nuclear-reactor waste.

Wol fsberg, K. 1978. Sorption-Desorption Studies of Nevada Test Site Alluvium and Leaching Studies of Nuclear Test Debris. LA-7216-MS, Los ATamos Scientific Laboratory, Los Alamos, New Mexico.

This informal report presents results of laboratory investigations for the RNM Project, which involves the study of radionuclide movement from sites of underground nuclear explosions at the Nevada Test Site. The report describes distribution coefficients determined for sorption-desorption of radioactive tracers between aliuvium and alluvial ground water. volatile and refractory debris samples from nuclear tests in tuff, alluvium, and rhyolite were leached with ground water. The most leachable were the volatile species $\mathrm{I}$, Mo, and Sb, which had condensed on chimney rubble. Comparison of the laboratory data with field measurements indicates that leaching is the main process responsible for the presence of radionuclides in water from the sites of the Cambric underground nuclear test. 
Wolfsberg, K. 1979. Sorption-Desorption Studies of NIS Alluvium and Leaching Studies of Nuclear Test Debris. Los Alamos National Laboratory, Los Alamos, New Mexico.

Distribution coefficients were determined for adsorption-desorption of radioactive tracers between NTS alluvium and alluvial ground water. Some distribution data were also obtained for bentonite. Volatile and refractory debris samples from nuclear tests in tuff, alluvium, and rhyolite were leached with ground water. Most leachable are the volatile species I, Mo, and $\mathrm{Sb}$, which have condensed on chimney rubble. Comparison of the laboratory data with field measurements indicates that leaching is the main process responsible for the presence of radionuclides in water from the site of the Cambric underground nuclear test.

Wolfsberg K., B.P. Gayhurst, B.M. Crowe, W.R. Daniels, B.R. Erdal, F.0. Lawrence, A.E. Norris, and J.R. Smyth. 1979. Sorption-Desorption Studies on Tuff: I. Initial Studies with Samples from the J-13 Drill Site, Jackass Flats, Nevada. LA-7480-MS, Los Alamos National Laboratory, Los Alamos, New Mexico.

Distribution coefficients were determined for adsorption-desorption of radionuclides between each of three types of tuff from drili hole $\mathrm{J}-13$ at the NTS and water from that well. The measurements were performed under atmospheric conditions at 71.6 and $158^{\circ} \mathrm{F}\left(22\right.$ and $\left.70^{\circ} \mathrm{C}\right)$. Sorption ratios varied greatly with lithologic variety of tuff.

\section{Modeling Studies}

Burbey, T.J., and S.W. Wheatcraft. 1986. Tritium and Chlorine-36 Miqration from a Nuclear Explosion Cavity. DOE/NV/10384-09, Desert Research Institute, University of Nevada System, Las Vegas, Nevada.

In this study, a conceptua? mode] of the Cambric cavity and surrounding hydrogeologic environment was formulated using available field data, such as core samples and the breakthrough curves of tritium and ${ }^{36} \mathrm{Cr}$. The conceptual model is treated as a hypothesis and tested using a three-dimensional numerical code that solves the appropriate governing transport equations for flow and solute concentration. Most hydraulic and dispersive parameters were held constant in the model, based on the analysis of field data.

Claassen, H.C. 1981. "Conceptual Modeis Governing Leaching Behavior and Their Long-Term Predictive Capability." Nuclear and Chemical Waste Management 2:307-313.

Six leaching models are considered, some of which lead to either illogical or unrealistic predictions when published data are extrapolated to long times. It is hypothesized that over longer times, processes occur that have not been observed in the usual shorter experiments. This hypothes is was tested using mass-transfer data from laboratory experiments that used natural volcanic glass to predict the composition of ground water. It is not now possible to deduce a single mass-transfer mechanism that could control the 
solution concentration of all components of all waste forms being investigated. Probably the most reasonable mechanisms are surface sorption and chemical precipitation on the surface of a substance not containing the species of interest, that is, presence of a diffusion-limiting layer. That sorption and chemical precipitation are factors limiting mass transfer has been verified in natural ground-water systems, although the diffusionlimiting mechanism has not yet been verified.

Claassen, H.C., and A.F. White. 1979. "Application of Geochemical Kinetic Data to Ground-Water Systems: A Tuffaceous-Rock System in Southern Nevada." In Chemical Modeling in Aqueous Systems, pp. 771-793. American Chemical Society Symposium Series, No. 93, American Chemical Society, Washington, D.C.

This document reports on the application of geochemical data from the Rainier Mesa aquifer system to an explicit hypothesis of ground-water movement that takes into account chemical reactivity, the ratio of active aquifer surface to solution volume, chemical composition of water, temperature, contact time, and the reaction rate, in addition to data from standard hydraulic testing procedures.

Czarnecki, J.B. 1985. Simulated Effects of Increased Recharge on the Ground-Water Flow System of Yucca Mountain and Vicinity, Nevada-California. Water Resources Investigations Report 84-4344, U.S. Geological Survey, Denver, Colorado.

A study was performed to assess the potential effects of changes in future climatic conditions on the ground-water system in the vicinity of Yucca Mountain. These changes would probably result in greater rates of precipitation and, consequently, greater rates of recharge. The study was performed by simulating the ground-water system using a two-dimensional, finte-element ground-water flow model.

Czarnecki, J.B., and R.K. Wadde11. 1984. Finite-Element Simulation of Ground-Water Flow in the Vicinity of Yucca Mountain, Nevada-Cal ifornia. Water Resources Investigation Report 84-4349, U.S. Geological Survey, Denver, Colorado.

A finite-element model of the ground-water flow system in the vicinity of Yucca Mountain at the NTS was developed using parameter-estimation techniques. The model simulated steady-state ground-water flow occurring in tufaceous, volcanic, and carbonate rocks and in alluvial aquifers. Hydraulic gradients in the modeled area range from 0.00001 for carbonate aquifers to 0.19 for barriers in tufaceous rocks. Three model parameters were used in estimating transmissivities in six zones. Simulated hydraulic-head values range from about $3,936 \mathrm{ft}(1,200 \mathrm{~m})$ near Timber Mountain to about $984 \mathrm{ft}$ $(300 \mathrm{~m})$, indicating an acceptable representation of the hydrologic system by the model. Sensitivity analyses of the model's flux boundary-condition variables were performed to assess the effect of varying boundary fluxes on the calculation of estimated model transmissivities. 
Feeney, T.A., M.E. Campana, and R.L. Jacobson. 1987. A DeuteriumCalibrated Groundwater Flow Model of the Western Nevada Test Site and Vicinity. DOE/NV/10384-16, Desert Research Institute, University of Nevada System, Las Vegas, Nevada.

A discrete-state compartment model, consisting of nine aquifer subregions, is calibrated with the stable isotope deuterium to delineate groundwater flow in the vicinity of the western NTS. Calibrated deuterium concentrations agree very closely with observed ones, except on eastern Pahute Mesa and Timber Mountain (which had no data for observed deuterium concentrations). Model flow paths and amounts are in relative agreement with previous studies The totai ground-water flow through the modeled area is $1.14 \mathrm{x}$ $10.9 \mathrm{ft}^{3} / \mathrm{yr}\left(32.4 \times 10^{6} \mathrm{~m}^{3} / \mathrm{yr}\right)$. Fortymile Canyon and Wash and Pahute Mesa are major recharge sites, accounting for 1.97 and $2.9 \times 10^{8} \mathrm{ft}^{3} / \mathrm{yr}^{2}(5.6$ and $8.1 \times 10^{6} \mathrm{~m}^{3} / \mathrm{yr}$ ) of recharge, respectively. Recharge, as a percentage of precipitation, is greatest in Fortymile and Stockade Washes, ranging between 5 and $12 \%$. In Crater Flat, Timber Mountain, and eastern Pahute Mesa, recharge is between 1 and $2 \%$ of precipitation. Major discharge areas occur in Oasjs Valley and the Amargosa Desert, discharging 0.9 and $10.17 \mathrm{x}$ $10^{8} \mathrm{ft}^{3} / \mathrm{yr}\left(2.7\right.$ and $\left.28.8 \times 10^{6} \mathrm{~m}^{3} / \mathrm{yr}\right)$, respectively. Ground-water mean ages range from 2,700 years at Ash Meadows to 9,200 years at Pahute Mesa, and represent minimum ground-water residence times. The deuterium model has not been verified, primarily because it is quite different from conventional ground-water flow models; hence, comparisons are difficult. However, it can be checked by constructing other discrete-state compartment models calibrated with other environmental tracers, such as ${ }^{14} \mathrm{C}$, a task currently in progress.

Foley, T.A., Jr. 1981. Off-Site Radiation Exposure Review Project: Computer-Aided Surface Interpolation and Graphical Display. DOE/DP/1253-45021, Water Resources Center, Desert Research Institute, University of Nevada System, Las Vegas, Nevada.

This report presents the implementation of an iterative procedure that solves the bivariate interpolation problem and applies it to characterization of the radionuclide activity resulting from nuclear tests.

Foley, T.A., Jr. 1981. NTS Radiological Assessment Project: Comparison of Delta-Surface Interpolation with Kriging for the Frenchman Lake Region of Area 5. DOE/DP/01253-45022, Water Resources Center, Desert Research Institute, University of Nevada System, Las Vegas, Nevada.

The primary objective of this study was to compare the results of delta-surface interpolation with kriging on four large sets of radiological data sampled in the Frenchman Lake region.

Montazer, P., and W. E. Wilson. 1984. Conceptual Hydrologic Model of Flow in the Unsaturated Zone, Yucca Mountain, Nevada. Water Resources Investigations Report 84-4345, U.S. Geological Survey, Denver, Colorado.

In this report, a conceptual model is proposed to describe the flow of fluids through porous layers intercalated with double-porosity layers. In 
the model, flow through fractures can occur at almost al1 stages of saturation, but the flux magnitude in fractures is largely a factor of the contrast between the matrix and fracture hydraulic properties and the magnitude of the perturbation of flux at the flow boundaries. Flow is retarded by capillary barriers at the contacts between welded and nonwelded units. The effectiveness of the capillary barrier depends on the magnitude of flux and hydraulic head distribution. Hysteresis during wetting phases and air entrapment may result in greater actual fTux in fractures than would be predicted. Both vapor transport and liquid flow can occur simultaneously within the fractured layers in this model.

Nimick, F.B., and R.L. Williams, 1984. A Three-Dimensional Geologic Model of Yucca Mountain, Southern Nevada. SAND83-2593, Sandia National Laboratories, Albuquerque, New Mexico.

The purpose of this report is to describe the initial version of the three-dimensional geologic model of Yucca Mountain. The report also describes the modeling method and configuration, the input data used, and an analysis of the model's predictive ability, with conclusions concerning the usefuiness of the model to the NNWSI project.

Oberlander, P.L. 1979. Development of a Quasi Three-Dimensional Groundwater Model for a Portion of the Nevada Test Site. NV0-1253-14, Desert Research Institute, University of Nevada System, Las Vegas, Nevada.

Ground-water systems are often modeled on computers using a finitedifference method in two dimensions, height and length. These models do not account for lateral water movement. An empirical correction matrix has been devised that will partialiy adjust a two-dimensional model for flow in the third dimension. In an isotropic and homogeneous medium, the correction matrix averages a $4.9 \%$ difference in potential vaiues. The correction matrix has been applied to the ground-water system from Pahute Mesa to Yucca Flat on the NTS, a distance of $15 \mathrm{mi}(24 \mathrm{~km})$. The geology of the area is complex and contains folded and thrust-faulted Paleozoic through Tertiary rocks. Ground water is recharged at Pahute Mesa and flows to Yucca Flat at the rate of 64.8 acre-feet/yr $\left(79,985 \mathrm{~m}^{3} / \mathrm{yr}\right)$. The maximum water flow under all of Yucca Flat and into the Ash Meadows ground-water system is 124 acre-feet/yr $\left(153,058 \mathrm{~m}^{3} / \mathrm{yr}\right)$.

Rice, W.A. 1984. Preliminary Two-Dimensional Regional Hydrologic Model of the Nevada Test Site and Vicinity (Draft). SAN093-7466, PNL-4919, Pacific Northwest Laboratory, Richland, Washington.

Pacific Northwest Laboratory documented the data requirements, boundary conditions, and calibration of a two-dimensional, finite-difference hydrologic model of the NTS and vicinity (southern Nevada and eastern California). The region modeled lies between $115^{\circ}$ and $118^{\circ}$ west longitude, and $35^{\circ}$ and $39^{\circ}$ north latitude. Underflow from areas north and east of the model boundary contribute a significant flux to model input; however, water balances within the model boundary are in good agreement with published values. The major discharge flux from the model occurs along the Death valley perimeter. If 
hydraulic head data and aquifer tests can be identified with hydrostratigraphic units, a two-layer, three-dimensional model can be constructed, which would more accurately simulate the physical system.

Streile, G.P., and C.S. Simmons. 1986. Subsurface Flow and Transport of Organic Chemicals: An Assessment of Current Modeling Capability and Priority Directions for Future Research (1987-1995). DOE/ER-0307, Pacific Northwest Laboratory, Richland, Washington.

The purpose of this study was to identify relevant technical issues, to explain why and how these issues impede progress in implementing codes, and to suggest research directions that may remedy current technical limitations. This study also assessed state-of-the-art modeling of subsurface movement and fate of organic chemicals. Directions for the development of the next generation of predictive models for analyzing problems of ground-water contamination by organic chemicals are suggested.

Wadde11, R.K., Jr. 1982. Two-Dimensional, Steady-State Model of GroundWater Flow, Nevada Test Site and Vicinity, Nevada-California. Water Resources Investigations 82-4085, U.S. Geological Survey, Denver, Colorado.

A two-dimensional, steady-state, finite-element model of the groundwater flow system of the NTS and vicinity in Nye and Clark Counties, Nevada, and Inyo County, California, was developed using parameter-estimation techniques. The model simulates flow in an area underlain by clastic and carbonate rocks of Precambrian and Paleozoic age and by volcanic rocks and alluvial deposits of Tertiary and Quaternary age. Normal basin-and-range faulting and both right-and left-lateral strike-slip faults have caused juxtaposition of rocks of differing hydraulic conductivities.

Wang, J.S.Y., and T.N. Narasimhan. 1985. Hydrologic Mechanisms Governing Fluid Flow in Partially Saturated, Fractured, Porous Tuff at Yucca Mountain. SAND84-7202, Sandia National Laboratories, Albuquerque, New Mexico.

An understanding of the mechanisms governing fluid flow in partially saturated, fractured tuff is needed to assess the suitability of Yucca Mountain in southern Nevada as a potential site for a radioactive-waste repository. In this report, a general statistical theory is proposed to describe flow along and across fractures that separate partially saturated matrix blocks. This theory incorporates a model for estimating fractureaperture distributions and yields expressions for fracture saturation, fracture permeability, and effective areas of matrix-fracture flow as functions of pressure. With these expressions, drainage of a fractured tuff column was simulated using the TRUST numerical model. The values for parameters in the expressions are deduced from observations of fracture spacings and orientations in samples from Yucca Mountain, measurements of pressure-saturation relationships of matrix core samples, and indirectly derived fracture-surface characteristics. In the simulations of the draining column, discrete vertical and horizontal fractures and intervening matrix blocks were explicitly taken into account. The simulations indicate that the transient change from fully saturated conditions to partially saturated conditions depends strongly 
on the fracture properties. The simulations also show that changes in fluid flow under nearly steady-state conditions in a partially saturated, fractured, porous system could be simulated approximately without taking the fractures into account. 

PNL-7101

UC-11

\section{DISTRIBUTION}

No. of

Copies

OFFSITE

10 DOE/Office of Scientific and Technical Information

10

D. R. Elle, Chief

EPD/EST Branch Nevada Operations office

U.S. Department of Energy P.0. Box 98518

Las Vegas, NV 89193-8518

P. A. Eddy

IT Corp.

4585 Pacheco Blvd.

Martinez, CA 94553

R. Jacobson

Water Resources Center

Desert Research Institute

University of Nevada System

2505 Chandler Ave., Suite 1

Las Vegas, NV 89120

K. V. Marsh

University of California

Lawrence Livermore National Laboratory

MS L-233

P.0. Box 808

Livermore, CA 94550
No. of

Copies

J. L. Thompson

Los Alamos National Laboratory

MS J-514

Los Alamos, NM 87545

ONSITE

DOE Richland Operations office

E. C. Norman

27 Pacific Northwest Laboratory

M. P. Bergeron (10)

J. W. Falco

M. G. Foley

L. K. Grove

J. M. Hales

R. P. Harrison

P. C. Hays

J. R. Raymond

R. L. Skaggs

J. A. Stottlemyre

R. W. Wallace

R. E. Wildung

Publishing Coordination

Technical Report Files (5) 
$\therefore$ 